medRxiv preprint doi: https://doi.org/10.1101/2022.02.06.22270509; this version posted February 8, 2022. The copyright holder for this preprint (which was not certified by peer review) is the author/funder, who has granted medRxiv a license to display the preprint in perpetuity.

All rights reserved. No reuse allowed without permission.

\title{
1 Decoding molecular programs in melanoma brain metastases
}

2 Josefine Radke ${ }^{1,2,3,4, \#, *}$, Elisa Schumann ${ }^{1,3, \#}$, Julia Onken ${ }^{5}$, Randi Koll ${ }^{1,3}$, Güliz Acker ${ }^{2,5}$, 3 Bohdan Bodnar ${ }^{5}$, Carolin Senger ${ }^{6}$ Sascha Tierling $^{8}$, Markus Möbs ${ }^{7}$, Peter Vajkoczy ${ }^{5}$, Anna 4 Vidal $^{13}$, Sandra Högler ${ }^{9}$, Petra Kodajova ${ }^{9}$, Dana Westphal ${ }^{10,11}$, Friedegund Meier ${ }^{10,11,12}$, Frank 5 Heppner ${ }^{1,2,3}$, Susanne Kreuzer-Redmer ${ }^{14}$, Florian Grebien ${ }^{13}$, Karsten Jürchott ${ }^{15}$ and Torben 6 Redmer ${ }^{9,13^{*}}$

$7 \quad$ *corresponding authors

8 \#equally contributing

$9{ }^{1}$ Department of Neuropathology, Charité-Universitätsmedizin Berlin, corporate member of

10 Freie Universität Berlin, Humboldt-Universität zu Berlin and Berlin Institute of Health, Berlin, 11 Germany

$12{ }^{2}$ Berlin Institute of Health (BIH), Berlin, Germany Germany 
Corresponding authors:

47 Torben Redmer

$48 \quad$ Email: torben.redmer@vetmeduni.ac.at

49 Josefine Radke

50 Email: josefine.radke@med.uni-greifswald.de

51

52

53

54

55

56

Word count (abstract): 224

Word count (main text): 10,874 (without figure legends+M\&M)

Figures: 8

Supplementary files: 9

Supplementary figures: 15

\section{Abstract}

The systemic dissemination of tumor cells and the spatiotemporal development of organmetastases are associated with loss of therapeutic control and decreased overall survival (OS). The emergence of solitary or multiple brain metastases is frequently observed in melanoma patients and responsible for disease progression and dismal prognosis. Here, we used whole transcriptome and methylome profiling as well as targeted sequencing (TargetSeq) of intraoperative/snap frozen or archived melanoma brain metastases to unravel molecular subgroups and subclonal heterogeneity. We discovered that E-cadherin (Ecad)/BRAF ${ }^{\mathrm{V} 600 \mathrm{E} / \mathrm{K}}, \mathrm{CD} 271 / \mathrm{NRAS} \mathrm{S}^{\mathrm{Q61L/R/K}}$, and tumor infiltrated lymphocytes (TIL)-status molecularly subdivided tumors into proliferative/pigmented and invasive/stem-like irrespective of the intracranial location. Moreover, we identified 46 differentially methylated regions in promoters of 14 genes, subdividing MBM into BRAF ${ }^{\text {mut }}$ and NRAS ${ }^{\text {mut }}$ subgroups. We observed that therapy-resistant, migratory $\mathrm{CD} 271^{+} / \mathrm{Ecad}^{\text {neg }}$ subclones derived from Ecad ${ }^{+}$ tumors in an epithelial-mesenchymal transition (EMT)-like process and fostered intracranial progression. Hence, CD271 high $M B M$ present a therapy-resistant, progressive subset of tumors that are refractory to conventional therapeutic strategies. The knockdown of CD271 or SOX4 in in vitro established, MBM-derived cell lines decreased cell migration, proliferation, and number of suspension cells that were shed by cell lines of progressive tumors. 
medRxiv preprint doi: https://doi.org/10.1101/2022.02.06.22270509; this version posted February 8, 2022. The copyright holder for this preprint (which was not certified by peer review) is the author/funder, who has granted medRxiv a license to display the preprint in perpetuity.

All rights reserved. No reuse allowed without permission.

In summary, we propose that an Ecad-to-CD271 switch of MBM is a rate-limiting process that potentially determines intracranial progression in melanoma patients. The therapeutic control of this process may prevent intracranial progression, increasing patient's overall survival.

\section{Introduction}

The development of brain metastases $(\mathrm{BM})$ is frequent in melanoma, lung and breast cancer $^{1,2}$. Despite much progress and remarkable response in a subset of patients ${ }^{3}$, small molecule inhibitors (BRAFi) or immune checkpoint inhibitors (ICi) blocking oncogenic BRAF or interfering with the PD-L1/PD1 axis to restore $\mathrm{T}$ cell activation are insufficient strategies to achieve long-lasting prevention of intracranial relapse and progression ${ }^{4,5}$. The latter is determined by emergence of multiple BM and therefore associated with poor prognosis ${ }^{3,6}$. Stage IV melanoma patients exhibit extracranial metastases at multiple organ sites facilitated by circulating tumor cells ${ }^{7}$ invading the sub-arachnoid space and cerebrospinal fluid (CSF $)^{8}$. It is assumed that primary tumor-derived cells acquire the capability of transmigration through the blood brain barrier (BBB) during the sequential steps of the metastatic cascade. Due to the difficulty of tracking of cellular subclones giving rise to BM human patients are seldom accessible to investigation. Therefore, the investigation of single BM, each presenting temporal snapshots, provides insights into the mechanisms of BM development and progression.

Melanoma cells that crossed the BBB initially remain in a dormant state and likely develop symptomatic macrometastases after a certain time of adaptation to the brain microenvironment or environmental trigger ${ }^{9-11}$. In fact, brain metastatic lesions are observed in more than $90 \%$ of melanoma patients post mortem ${ }^{12,13}$, proposing that only a minority of micrometastases successfully establishes macrometastases. The time from initial diagnosis of primary tumors to the detection of BM ranges from 1-10 years, supporting the assumption of a slow evolutionary process of BM in $20-40 \%$ of melanoma patients ${ }^{3,14}$. The median 
medRxiv preprint doi: https://doi.org/10.1101/2022.02.06.22270509; this version posted February 8, 2022. The copyright holder for this preprint (which was not certified by peer review) is the author/funder, who has granted medRxiv a license to display the preprint in perpetuity.

All rights reserved. No reuse allowed without permission.

105

106

107

108

109

110

111

112

113

114

115

116

117

overall survival of melanoma patients after diagnosis of a BM (MBM) is 8.9 months $^{15}$ and is determined by the speed of intracranial progression that in turn depends on the efficacy of development of macrometastases and the response to therapeutic interventions.

MBM like extracranial metastases (Met) comprise numerous genetic subclones that variably respond to BRAFi, ICi and radiotherapy due to intrinsic or acquired mechanisms of resistance consequently fostering tumor relapse within approximately $6-11$ months ${ }^{16-18}$. So far, the presence or acquisition of mutations in NRAS (p.Q61K/L), MEK1 (p.P124), RAC1 (p.P29S) or gain of a secondary mutation in BRAF (p.L514K) have been attributed to confer BRAFi resistance ${ }^{19,20}$. In addition, BM exhibiting increased DNA repair capacity and/or low proliferative capacity present a low response to radiation therapy ${ }^{21}$ and melanoma expressing IPRES (innate anti-PD-1 resistance) signature genes is resistant to ICi-based therapies $^{22}$. However, expression of cell surface markers serving as targets of antibodybased therapies is unstable and regulated by phenotype switching. The latter process is responsible for a non-genomic cellular heterogeneity and is triggered by pro-inflammatory cytokines that are released in response to therapy-induced tumor cell stress or from microenvironmental cells such as astrocytes or microglia ${ }^{23,24}$. In particular, astrocytes are implicated in the maintenance of BBB permeability, extracellular homeostasis and essentially involved in the response towards brain damaging events ${ }^{25,26}$. The interaction of brain tumors with astrocytes triggers astrogliosis, that results in secretion of cytokines promoting the survival and invasion of tumor cells ${ }^{27}$. Hence, inflammation-triggered mechanisms might drive the progression of MBM via a subset of dedifferentiated and highly migratory cancer stemlike tumor cells (CSCs) $)^{23,28}$. The latter comprise a minor tumor cell subset exhibiting cellular plasticity, display elevated intrinsic resistance to several therapeutic drugs and feature a neural crest stem cell (NCSC)-like phenotype in melanoma ${ }^{29-31}$. The maintenance of the NCSC-state of melanoma cells depends on the expression of the nerve growth factor receptor and non-receptor tyrosine kinase CD271 that is associated with a network of several downstream targets ${ }^{28,32-34}$ and non-genetic emergence of minimal-residual disease $(\mathrm{MRD})^{35,36,28,33,34}$. Recent work has shown that melanoma cells secreted extracellular vesicles 
medRxiv preprint doi: https://doi.org/10.1101/2022.02.06.22270509; this version posted February 8, 2022. The copyright holder for this preprint (which was not certified by peer review) is the author/funder, who has granted medRxiv a license to display the preprint in perpetuity.

All rights reserved. No reuse allowed without permission.

133 were enriched with CD271 that was taken up by lymphatic endothelial cells, therefore aiding

134 lymph node metastasis ${ }^{37}$.

135 On the other hand, CD271 controls migratory programs of melanocytes ${ }^{38}$ that are connected 136 with keratinocytes via E-cadherin (Ecad)-mediated adhesive junctions in the skin. The 137 downregulation of Ecad is tightly controlled by a set of transcription factors mediating the 138 transition of epithelial to mesenchymal (EMT) states and is a prerequisite for melanocyte 139 migration and their malignant transformation ${ }^{39}$. However, the expression of Ecad is essential 140 to establish stemness and is restored in primary melanoma and organ-specific 141 metastases ${ }^{40,41,42}$.

142 Likely, BM emerge and progress by the concerted interaction of several molecular programs 143 that are triggered by cells of the tumor microenvironment (TME) and/or in response to 144 therapeutic interventions. To gain insight into molecular mechanisms controlling the 145 maintenance and progression of BM, we performed a whole transcriptome and methylome 146 profiling as well as targeted sequencing (TargetSeq) of intraoperative or cryo-preserved 147 MBM $(n=16)$ and established MBM-derived cellular model systems. Here, we provided 148 evidence that therapeutic interventions inhibiting the acquired constitutive activation of BRAF likely foster the phenotype switch from Ecad ${ }^{+}$into NGFR/CD271 ${ }^{+}$cells.

\section{Material and Methods}

152

153

154

\section{Patient cohorts}

Intraoperative brain metastases of sixteen patients with diagnosed stage IV melanoma (MBM) were surgically removed at the Department of Neurosurgery, Charité Universitätsmedizin Berlin, Germany. Tumor pieces were split into parts of equal size and either i) snap-frozen and stored at $-80{ }^{\circ} \mathrm{C}$ or ii) directly used for the establishment of MBMderived cell lines or iii) isolation of RNA and DNA or formaldehyde-fixed and paraffinembedded (FFPE) and archived. Cerebrospinal fluid (CSF) of patient 8 was collected by 
medRxiv preprint doi: https://doi.org/10.1101/2022.02.06.22270509; this version posted February 8, 2022. The copyright holder for this preprint (which was not certified by peer review) is the author/funder, who has granted medRxiv a license to display the preprint in perpetuity.

All rights reserved. No reuse allowed without permission.

159 lumbar puncture. All patients gave written informed consent for the collection and scientific

160 use of tumor material which was collected at the Biobank of the Charité - Comprehensive

161 Cancer Center (CCCC) following ethics approval (EA1/152/10; EA1/107/17; EA4/028/18). In

162 addition, thirty-two MBM archived at the Department of Neuropathology, Charité-

163 Universitätsmedizin Berlin, Germany, were included in the study and analyzed. The usage of

164 archived (FFPE) melanoma and central nervous system-derived control samples (pons,

165 cortex, cerebellum) has been reviewed and approved by the local ethics committee

$166(\mathrm{EA} 1 / 107 / 17$ and $\mathrm{EA} 1 / 075 / 19)$.

167

168 Cell culture

169 Conventional melanoma cell lines

170 BMCs and conventional melanoma cell lines were kept at $37^{\circ} \mathrm{C} / 5 \% \mathrm{CO}_{2}$ and $95 \%$ humidity

171 in cell culture medium (DMEM, $4.5 \mathrm{~g} / \mathrm{L}$ glucose, stabilized glutamine/GlutaMax, pyruvate,

172 Gibo/ThermoFisher) supplemented with 10\% fetal bovine (FBS, Gibco) serum and 1\%

173 penicillin/streptomycin (P/S) (Gibo/ThermoFisher). BMCs were kept at low passages (2-20)

174 and split according to their proliferative capacity $(1: 2-1: 10)$ at a confluence of $\sim 80 \%$. Cells

175 were seeded onto glass 8 -chamber slides to a density of $5,000-10,000$ cells per chamber.

176 A375, T2002, MeWo cells and human melanocytes were cultured as previously reported ${ }^{33}$.

177

$178 \quad$ MBM-derived cell lines

179 Intraoperative tumors were surgically resected during routine craniotomy and processed to 180 establish brain metastases-derived cell lines (BMCs) as following: Tumor pieces were stored 181 in physiological saline, $0.9 \%$ on ice until further processing. Following mincing using scalpels, 182 the mechanically dissociated tissue was transferred to a $15 \mathrm{ml}$ falcon tube containing 183 trypsin/EDTA (0.05\%) and incubated at $37^{\circ} \mathrm{C}$ in a water bath for up to 20 minutes. In 184 addition, the tissue was mechanically dissociated by usage of a Pellet Mixer (VWR 185 International). The cell suspension was applied to a $70 \mu \mathrm{m}$ cell strainer to remove undigested 186 tissue fragments and cells in the flow-through were collected by centrifugation at $330 \mathrm{~g}$ for 5 
medRxiv preprint doi: https://doi.org/10.1101/2022.02.06.22270509; this version posted February 8, 2022. The copyright holder for this preprint (which was not certified by peer review) is the author/funder, who has granted medRxiv a license to display the preprint in perpetuity.

All rights reserved. No reuse allowed without permission.

187 minutes. Collected cells were resuspended in cell culture medium (DMEM, $4.5 \mathrm{~g} / \mathrm{L}$ glucose, 188 stabilized (GlutaMax) or conventional glutamine, pyruvate, 10\% FBS, 1\% P/S) and seeded on appropriate cell culture dishes. Cells were maintained for at least three days without medium change to achieve optimal recovering and attachment of tumor cells.

\section{BrdU labeling}

For labeling, cells were maintained for $2 \mathrm{~h}$ in medium containing BrdU (Becton\&Dickinson) at

a final concentration of $2 \mathrm{mM}$. Subsequently, cells were washed with phosphate buffered saline (PBS) and fixed with freshly prepared paraformaldehyde (4\% in PBS) for $10 \mathrm{~min}$ at room temperature and washed and permeabilized by Triton-X100 (0.1\%/PBS). Following, cells were treated with hydrochloric acid $(2 \mathrm{M})$ for 10 min and washed twice with PBS. For BrdU detection, labeled cells were incubated with anti-BrdU-AlexaFluor488 for $1 \mathrm{~h}$ at room temperature or overnight at $4^{\circ} \mathrm{C}$ and washed with PBS-Tween20 (PBST; 0.1\%/PBS). Images were taken with Leica fluorescence microscope (Zeiss Axioskop 2) and edited by Adobe Photoshop 2020 using the gradation curve and picture size function. Images were adjusted to a resolution of $600 \mathrm{dpi}(\mathrm{RGB})$. BrdU-positive cells were quantified by counting and related to the total number of cells.

\section{Flow cytometry/Fluorescence-activated cell sorting (FACS)}

After removal of medium, cells were washed with PBS and harvested by Trypsin $(0.05 \%$ Trypsin/EDTA). Following addition of cell culture medium, cells were collected by centrifugation at $330 \mathrm{~g}$ at room temperature for $3(\mathrm{~min})$ and resuspended in $100 \mu \mathrm{l}$ of ice cold buffer (PBS/0.5 \% bovine serum/2 mM EDTA) and stored on ice. Cells were incubated with fluorescently labeled primary antibodies against CD271-PE (Miltenyi) DECMA1-APC

211 (recognizing the N-terminal domain of E-cadherin, Biolegend), and non-labeled antibodies against AXL (Novus biologicals), PD-L1 (BioLegend), c-MET (MET, Cell signaling) or KBA.62

213 (BioLegend) diluted in buffer according to the manufacturer's specifications and stored at $4^{\circ} \mathrm{C}$ 214 for 10 min to achieve proper labeling. Following, cells were washed by addition of buffer, 
medRxiv preprint doi: https://doi.org/10.1101/2022.02.06.22270509; this version posted February 8, 2022. The copyright holder for this preprint (which was not certified by peer review) is the author/funder, who has granted medRxiv a license to display the preprint in perpetuity.

All rights reserved. No reuse allowed without permission.

215 collected by centrifugation and resuspended in $100 \mu \mathrm{l}$ of buffer that contained secondary

216 antibodies (AlexaFluor-488/594/647) and/or DAPI, diluted according to the manufacturer's

217 specifications. After incubation for $10 \mathrm{~min}$ at $4^{\circ} \mathrm{C}$ and washing, cells were resuspended in

$218500 \mu \mathrm{l}$ PBS and analyzed by flow cytometry (Canto II) or fractioned by FACS using a

219 FACSAria' ${ }^{\mathrm{TM} I I I}$ cell sorter (Becton\&Dickinson, BD). FACS-isolated cells were collected in cell

220 culture medium and seeded on appropriate vessels following centrifugation. Data analysis

221 was performed with FlowJo (Ver 10.7.1).

222

223 Immunophenotyping

224 Immunofluorescence (IF)

225 Two micrometer sections of FFPE tumors were dewaxed and subjected to antigen retrieval

226 with citrate buffer $(10 \mathrm{mM}, \mathrm{ph}=6.0)$ and heating for $20 \mathrm{~min}$ in a steamer. Cooled sections

227 were blocked with blocking buffer (2\% BSA/PBS) to reduce unspecific binding. Primary

228 antibodies (p75NTR, Cell signaling/CST, \#8238, mAb rabbit, clone D4B3, 1:100; E-cadherin,

229 CST\#3195, mAb rabbit, clone 24E10, 1:200; E-cadherin, Santa Cruz, sc-8426, mAb mouse,

230 clone G10, 1:50; E-cadherin-AlexaFluor647, BioLegend, 147308, mAb rat, clone DECMA-1,

231 1:50; KBA.62, NovusBiologicals, NBP2-45285, mAb mouse, 1:100; GFAP-AlexaFluor594,

232 BioLegend, 644708, mAb mouse, clone 2E1.E9, 1:200; STAT5A, Abcam, ab32043, mAb

233 rabbit, clone E289, 1:100; AXL, CST, \#8661, mAb rabbit, clone C89E7, 1:100 and

234 phospho(Tyr779)-AXL, R\&D Systems, mAb mouse, clone 713610, 1:50 were diluted in

235 blocking buffer and incubated for $2 \mathrm{~h}$ at room temperature or overnight at $4^{\circ} \mathrm{C}$. After washing

236 with PBST, secondary antibodies and DAPI all diluted to 1:500 in blocking buffer were

237 applied to sections and incubated at room temperature for $1 \mathrm{~h}$. Following washing, sections

238 were covered with mounting medium and cover slips and stored at $4^{\circ} \mathrm{C}$ until fluorescence

239 microscopy-based imaging.

$240 \quad$ Immunohistochemistry (IHC)

241 Automated histological staining was performed on the BenchMark Ultra platform (Ventana) or 242 autostainer (Agilent) using p75NTR, CST, \#8238, mAb rabbit, clone D4B3, 1:100, c- 
medRxiv preprint doi: https://doi.org/10.1101/2022.02.06.22270509; this version posted February 8, 2022. The copyright holder for this preprint (which was not certified by peer review) is the author/funder, who has granted medRxiv a license to display the preprint in perpetuity.

All rights reserved. No reuse allowed without permission.

243 MET/MET, CST, \#8741, mAb mouse, clone L6E7, 1:100), phospho(Tyr1234/1235)-MET

244 CST, \#3077, mAb rabbit, clone D26, 1:100; AXL, CST, \#8661, mAb rabbit, clone C89E7,

$2451: 100$ or STAT5A, Abcam, ab32043, mAb rabbit, clone E289, 1:100.

246

247 RNA isolation and sequencing

248 Isolation of total RNA from snap frozen or intraoperative tumors was performed with the

249 RNAeasy extraction kit (Quiagen) according to the manufacturer's instructions. RNA integrity

was determined by automated electrophoresis (4200 TapeStation system, Agilent). The

library preparation of $100 \mathrm{ng}$ total RNA was performed with TruSeq Stranded total RNA

Sample Preparation-Kit and Ribo Zero Gold (Illumina) and paired-end (2x100 bp) whole

transcriptome profiling of RNA with integrity numbers $(\mathrm{RIN}) \geq 7$ was performed at Cegat

GmbH, Tuebingen (Germany) and sequenced on NovaSeq6000 platform. Illumina bcl2fasta

(2.19) was used for demultiplexing of sequenced reads and adapter trimming was performed with Skewer (version 0.2.2) ${ }^{43}$. The information on FASTQ files was obtained using the FastQC program (version 0.11.5-cegat) read out. Raw sequencing data (fastq files) were quality controlled using fastqc (version 0.11 .7 - Bioinformatics Group at the Babraham Institute) and further preprocessed with fastp ${ }^{44}$. Reads were aligned to the GRCh38 version of the human genome using $\mathrm{TopHat}^{45}$ and counts per gene were calculated by the featureCount-algorithm from the Rsubread package ${ }^{46}$. All further steps of the analysis were done in R. Raw counts of protein-coding genes were normalized using the DESeq2 (https://bioconductor.org/packages/release/ bioc/html/DESeq2.html) package ${ }^{47}$. Differential expression of genes between groups was determined after fitting models of negative binomial distributions to the raw counts. Raw p-values were FDR (false discovery rate)adjusted for multiple testing and a value below 0.05 for the adjusted $p$-values were used to determine significant differentially expressed genes. Functional annotation of genes, over representation and gene set enrichment analysis were done using the clusterProfiler 
medRxiv preprint doi: https://doi.org/10.1101/2022.02.06.22270509; this version posted February 8, 2022. The copyright holder for this preprint (which was not certified by peer review) is the author/funder, who has granted medRxiv a license to display the preprint in perpetuity.

All rights reserved. No reuse allowed without permission.

used ComplexHeatmap ${ }^{49}$ https://www.bioconductor.org/packages/release/bioc/ html/Complex

271 Heatmap.html).

272

273 Genetic profiling

274 For amplicon-based targeted DNA-sequencing, 10 - 40 ng of DNA was isolated from stored 275 snap frozen and archived FFPE tumor tissue or from cell lines using the DNeasy Blood \& 276 Tissue or the QIAamp DNA FFPE Tissue Kit and used for library preparation. Sequencing of 277 cancer hotspot (CHP2v, ThermoFisher) or TruSight Oncology 500 panel (Illumina) libraries was performed with benchtop sequencers IonProton (Thermo fisher) or NextSeq2000 279 (Illumina) with 775X mean coverage (Supplementary Table 6). Sequencing results were analyzed with VariantCaller software and validated using databases such as Varsome, COSMIC, and the 1000 Genomes project ${ }^{50}$. Data of the latter enabled the separation of single nucleotide polymorphisms (SNPs) from mutations (single nucleotide varaints, SNVs). Copy number analyses of targeted-sequencing reads of multiple sites of a certain gene was performed using binary alignment map (BAM) and BAM index (bai) files and the

CNVPanelizer R-script (https://www.bioconductor.org/packages/release/bioc/html/ CNVPanelizer.html). We used OncoPrint for visualization of the genomic alterations (https://jokergoo.github.io/ComplexHeatmap-reference/book/oncoprint.html).

Production of retroviral and lentiviral particles

290 For production of lentiviral particles, LentiX cells were seeded to $1 \times 10^{4}$ cells on a $10 \mathrm{~cm}$ dish and transfected after $24 \mathrm{~h}$ with $4 \mu \mathrm{g}$ of plasmids either expressing the DOX (doxycycline)inducible, SOX4 targeting shRNA (GEPIR Sox4.2137, Addgene \#101119) or mutant RAC1 $^{\text {P29S }}$ (pHAGE-RAC1-P29S, Addgene \#116650) and 2 ug of pMD2.G (Addgene \# 12259, VSV-G envelope) and $1 \mu \mathrm{g}$ of psPAX2 (\#12260) packaging plasmids using $20 \mu \mathrm{l} / 1 \mathrm{ml}$ Polyethylenimine (PEI, Sigma-Aldrich). Medium was changed after $24 \mathrm{~h}$ and viral supernatant was harvested after additional $24 \mathrm{~h}$. Viral supernatants were filtered through a $0.45 \mu \mathrm{m}$ filter and applied to target cells for 24-48h. Retroviral particles were produced in HEK-GP cells 
medRxiv preprint doi: https://doi.org/10.1101/2022.02.06.22270509; this version posted February 8, 2022. The copyright holder for this preprint (which was not certified by peer review) is the author/funder, who has granted medRxiv a license to display the preprint in perpetuity.

All rights reserved. No reuse allowed without permission.

following the above protocol. Plasmids expressing wildtype or mutant (S710F) STAT5A under control of the murine stem cell virus promoter (MSCV) or empty control were kindly provided by Dr Richard Moriggl. The knockdown of CD271/NGFR was performed with a DOX-inducible shRNA (SMARTvector, Dharmacon, clone ID V3SVHS02_8785341). Transgene expression was induced and maintained with DOX at a final concentration of 4 $\mu \mathrm{g} / \mathrm{ml}$. Virally transduced cells were selected for puromycine (Puro) resistance using a final concentration of $10 \mu \mathrm{g} / \mathrm{ml}$ Puro. Stable selection was achieved after passaging and growth of cells in presence of Puro for $\sim 3$ passages.

\section{Methylome profiling}

For global methylome analysis, DNA of snap frozen or FFPE MBM was isolated according to standard procedures using the DNeasy blood and tissue DNAextraction kit (Qiagen, Hilden, Germany). 500 ng genomic DNA were subjected to bisulfite conversion using the EZ DNA Methylation-Gold Kit (Zymo Research) according to the manufacturer's protocol. Subsequently, samples were analysed on the Infinium MethylationEPIC Kit (Illumina) according to the manufacturer's recommendations to obtain genome-wide data from 850,000 CpG positions. Raw data from Illumina Epic arrays were preprocessed and analyzed in the standard workflow of the packages $\mathrm{RnBeads}^{51}$ and watermelon ${ }^{52}$. Differential methylation analysis was conducted on site and region level according to the sample groups regarding their levels of E-cadherin or NGFR expression or level of immune cell infiltration (TIL status) or mutation status of BRAF. For statistical analysis, p-values on the site level were computed using the limma method. I.e. hierarchical linear models from the limma package were employed and fitted using an empirical Bayes approach on derived M-values.

\section{Gene-set enrichment GSEA/Single-sample GSEA}

GSEA was performed using the most current BROAD javaGSEA standalone version (http://www.broadinstitute.org/gsea/downloads.jsp) and gene signatures of the molecular signature database $\mathrm{MsigDB}^{53,54}, 7.4$ (Hallmark, C2) as well as published signatures 
medRxiv preprint doi: https://doi.org/10.1101/2022.02.06.22270509; this version posted February 8, 2022. The copyright holder for this preprint (which was not certified by peer review) is the author/funder, who has granted medRxiv a license to display the preprint in perpetuity.

All rights reserved. No reuse allowed without permission.

326 specifying different phenotypic states of melanoma such as "Melanoma aggressiveness ${ }^{55 ",}$ 327 "Proliferation", "Invasion"56, parts of the IPRES signatures ("MAPKi-induced EMT"57") and 328 MITF-target gene signature ("MITF_Targets_TCGA ${ }^{58 ")}$ ). The NGFR ${ }^{\text {high }}$ gene signature that 329 defines anti-PD-1 therapy resistance was kindly provided by Oscar Krijgsman and Daniel S. 330 Peeper $^{59}$ and overlaps with our identified set of CD271-associated genes ${ }^{32,33}$. Gene 331 signatures defining the undifferentiated neural-crest cell state were taken from Tsoi et al. ${ }^{60}$ 332 Analyses of single signatures were run using 10,000 permutations; analyses of signature collections were run using 1,000 permutations. Genes were ranked based on the

334 Signal2Noise metric. Ecad- and CD271-associated gene signatures were defined by the 335 comparative analysis of Ecad ${ }^{\text {high }}$ or CD271 ${ }^{\text {high }}$ vs low MBM.

\section{Confocal microscopy}

High-resolution immunofluorescence imaging of tumor sections and cell lines was performed with an LSM880 airyscan confocal microscope (Zeiss) and appropriate software (Zen black, ver. 2.3 SP1). Images were taken with objectives 10x, 20x and $63 x / 1.40$ plan-apochromat, oil dic M27) at a resolution of $2048 \times 2048$ pixels/cm, 8 bit, scan speed 6 , averaging 4 . Imersol 518F was used for oil microscopy. Stacked multichannel image files (czi) were separated and background adjusted using AdobePhotoshop2020 and stored as merged tiff files at a resolution of $600 \mathrm{dpi}$. Z-stacks were converted into three-dimensional images using the arivis tool of ZEN2 software.

\section{D-invasion assays}

Briefly, $50 \mu$ l of ice cold matrigel (Corning, 734-0270) were plated per well of a cooled 96-well plate and incubated for $10 \mathrm{~min}$ in a standard cell culture incubator at $37^{\circ} \mathrm{C}$. After matrigel polymerization, 2,500 cells of BMCs were plated on top of the matrigel layer in $100 \mu \mathrm{l}$ medium. Images were taken every 3 days for tracking of spheroid formation. 
medRxiv preprint doi: https://doi.org/10.1101/2022.02.06.22270509; this version posted February 8, 2022. The copyright holder for this preprint (which was not certified by peer review) is the author/funder, who has granted medRxiv a license to display the preprint in perpetuity.

All rights reserved. No reuse allowed without permission.

354

\section{Live cell imaging-based migration assays}

The migratory capacity of unmodified or modified shRNA or reporter expressing BMCs was assessed using the Incucyte ${ }^{\circledR}$ Zoom live-cell imaging system. Briefly, $3 \times 10^{4}$ cells $/$ well of each cell line were seeded on 96 -well plates $24 \square \mathrm{h}$ before, yielding a dense cell layer. Reproducible scratches were performed using the Incucyte ${ }^{\circledR}$ WoundMaker tool (EssenBioscience/ Sartorius) and floating cells were removed by gentle washing of wells with medium.

After wounding, the 96-well plate was placed into the live-cell imaging system and cell migration was monitored every $4 \square \mathrm{h}$ for 7 days, using a $\times 10$ magnification. Serial pictures were stacked for movie preparation using the ImageJ software (https://imagej.nih.gov/ij/). Statistical analysis was performed by using a two-tailed, paired t-test.

\section{Western blotting}

Whole protein was isolated from frozen cell pellets using RIPA buffer and protein concentration of lysates was determined by Bradford assays (Pierce ${ }^{\mathrm{TM}}$ Coomassie Plus Assay Reagent, Thermo). $25-40 \mu \mathrm{g}$ of total protein lysates were separated on $12 \%$ SDSPAGE gels and transferred to PVDF membranes (Merck) by using the turbo semi-dry blotting system (BioRad). Membranes were blocked with 5\% BSA solution and incubated with primary antibodies (CD271, clone D4B3, XP, Cell signaling; and $\beta$-Tubulin, clone 9F3 both from Cell Signaling Technology, Germany; all diluted 1:1000) overnight at $4^{\circ} \mathrm{C}$. For signal detection membranes were washed twice with PBS-Tween20 (0.1\%) and incubated with a horse radish peroxidase (HRP)-coupled secondary antibody (goat anti-rabbit lgG, Cell signaling) for $1 \mathrm{~h}$ at RT and analyzed with an automated imaging system (Vilber).

\section{Animal experiments}

All experiments with animals were performed in accordance with the German Animal Protection Law under the permission number G0130/20 obtained via the Berlin Ministry of Health and Social Affairs (LaGeSo). ARRIVE 2.0 Guidelines were strictly followed. Female 
medRxiv preprint doi: https://doi.org/10.1101/2022.02.06.22270509; this version posted February 8, 2022. The copyright holder for this preprint (which was not certified by peer review) is the author/funder, who has granted medRxiv a license to display the preprint in perpetuity.

All rights reserved. No reuse allowed without permission.

382 CD-1 nude mice (8-9 weeks of age, 24-26g, Charles River Laboratories) were 383 stereotactically inoculated with $2.5 \times 10^{4}$ BMC1-M1 and BMC1-M4 cells using a $1 \mu$ l Hamilton 384 syringe and a stereotactic frame as described previously ${ }^{61}$. Briefly, the bur hole was placed 2 $\mathrm{mm}$ lateral (right) and $1 \mathrm{~mm}$ rostral from the bregma. The cells were administered at a depth of $3 \mathrm{~mm}$. The number of cells used for the inoculation was determined in accordance with previous literature with the established human melanoma cell line $\mathrm{M} 14^{62}$. For the procedure, the animals received anesthesia (9mg Ketamine-Hydrochloride (CP-Pharma Handelsgesellschaft mbH, Burgdorf, Germany) $+1 \mathrm{mg}$ Xylazine (CP-Pharma Handelsgesellschaft mbH, Burgdorf, Germany) per $100 \mathrm{~g}$ ) intraperitoneally as well as subcutaneous prophylaxis against infection (10'000 I.E, benzylpenicillin potassium, InfectoPharm Arzneimittel und Consilium

Deutschland GmbH \& Co. KG, Melsungen, Germany), Lidocaine (Aspen Germany GmbH,

GmbH, Munich, Germany) was administered via the drinking water for the first two postoperative days. Following the procedure, MRI scans were performed every 7 days until either the tumor volume was above $20 \mathrm{~mm}^{3}$ or at latest on the 49th day after implantation. Animals were sacrificed by perfusion with 4\% PFA in deep anesthesia. The animals were kept in a 12-hour light-dark cycle and had ad libitum access to water and food. Examinations for general and neurological symptoms were performed once a day and on the first two postoperative days twice a day. The weight was measured postoperatively once a day followed by regular weight monitoring once a week.

For assessment of the proliferative capacity of non-metastatic melanoma cells (A375) $1 \times 10^{3}$ cells/ $\mu$ l were injected into the right hemisphere of NOD scid gamma (NSG) mice, carried out by EPO GmbH (Berlin, Germany). Tumor growth was tracked by bioluminescent imaging.

407 Mouse brains $(n=3)$ were formaldehyde fixed and embedded after $\sim 25 d$. Brain sections (2 $\mu \mathrm{m})$ were processed for immunofluorescence and confocal imaging as described. 
medRxiv preprint doi: https://doi.org/10.1101/2022.02.06.22270509; this version posted February 8, 2022. The copyright holder for this preprint (which was not certified by peer review) is the author/funder, who has granted medRxiv a license to display the preprint in perpetuity.

\section{Magnetic Resonance Imaging (MRI)}

412 The MRI scans were performed using a 7 Tesla small animal MRI (BioSpec 70/20USR or 413 PharmaScan 70/AS, Bruker Biospin, Ettlingen, Germany and ParaVision 6.0.1 or 5.1 414 software). During the scans, the mice received inhalation anesthesia $(1.0-1.5 \%$ Isoflurane 415 (CP-Pharma Handelsgesellschaft $\mathrm{mbH}$, Burgdorf, Germany) in a mixture of $30 \%$ oxygen and $70 \%$ nitrous oxide). The depth of the anesthesia was monitored using the respiratory frequency (70-120 breaths per minute). $T 1$ weighted sequences $(T R=1,000 \mathrm{~ms}$, TE $=10$ ms, RARE factor $=2,3$ averages for BioSpec; TR $=975 \mathrm{~ms}, \mathrm{TE}=11.5 \mathrm{~ms}$, RARE factor $=2$, 4 averages for PharmaScan) after intraperitoneal administration of gadolinium-based contrast agent (12,09 $\mathrm{mg}$ per mouse in a solution with $180 \mu \mathrm{l} 0,9 \% \mathrm{NaCl}$, Gadovist, Bayer AG, Leverkusen) and T2 (TR $=4,200 \mathrm{~ms}, \mathrm{TE}=36 \mathrm{~ms}$, RARE factor $=8,3$ averages for Biospec and TR $=4,200 \mathrm{~ms}, \mathrm{TE}=36 \mathrm{~ms}$, RARE factor $=8,4$ averages for PharmaScan) were measured. The tumor volume was measured using ITK-SNAP 3.8.0 Software ${ }^{63}$ (Paul A. Yushevich, Guido Gerig, www.itksnap.org).

\section{Quantitative real-time PCR}

RNA isolation from frozen cell pellets was performed with the RNeasy Mini Kit (Qiagen, Germany) and, following the manufacturers protocol. Reverse transcription of $500 \mathrm{ng}-2.5 \mu \mathrm{g}$ RNA was performed with SuperScript VILO cDNA synthesis kit (Invitrogen, Germany) and diluted to a final volume of $50 \mu \mathrm{l}$. qRT-PCR was carried out on a Step one plus PCR cycler (Applied Biosystems, Germany) for $30-40$ cycles. Primers were designed for $55-60^{\circ} \mathrm{C}$ annealing temperatures. Relative expression levels were calculated with the $\Delta \Delta \mathrm{CT}$ method $^{64}$, normalized to $\beta$-actin. Primer sequences are shown in Supplementary Table 9.

\section{Drug sensitivity assays}

436 The response of BMCs and conventional melanoma cell lines to dabrafenib, tivantinib in a 437 range of $1 \mathrm{nM}-10 \mu \mathrm{M}$ and paclitaxel in a range of $1 \mathrm{pM}-10 \mathrm{nM}$ of eight technical replicates was 
medRxiv preprint doi: https://doi.org/10.1101/2022.02.06.22270509; this version posted February 8, 2022. The copyright holder for this preprint (which was not certified by peer review) is the author/funder, who has granted medRxiv a license to display the preprint in perpetuity.

All rights reserved. No reuse allowed without permission.

438 determined densitometrically after $72 \mathrm{~h}$ and fixation/staining with crystal violet. Drug 439 treatments were performed $24 \mathrm{~h}$ after seeding of 5,000 cells/96-well. Live-cell imaging-based 440 drug responses were performed accordingly. Images were taken every three hours using a 441 10x objective and the general label-free mode, two pictures of eight technical replicates per 442 condition were taken. Drug response was assessed by changes in the cellular density over 443 time. The cell density was determined by a confluence mask tool as part of the Incucyte 444 software. IC50 values were calculated by curve-fitting (https://search.r-project.org/CRAN/ 445 refmans/REAT/html/curvefit.html) based on confluence measurements at day 3.

447 Data deposit

448 Whole transcriptome and methylome data were deposited in the European Genome-

449 Phenome Archive (EGA), under accession numbers EGAS00001005976 and 450 EGAS00001005975 (https://ega-archive.org/).

451

\section{Results}

\section{Therapeutic interventions promote the development of invasive brain metastases}

454 The investigation of longitudinal and synchronous BM can provide insights into the processes that control clonal and subclonal evolution, the driving forces of tumor progression. Metastatic melanoma is still a devastating disease as patients with stage IV melanoma

457 present with metastases at multiple extracranial and intracranial sites ${ }^{65,66}$. Presumably, the development of extracranial metastases precedes BM formation (Fig. 1a). Several lines of evidence suggest that therapeutic interventions enhance the emergence of therapy-resistant cellular subclones driving relapse and intracranial progression of $\mathrm{MBM}^{67-69}$. To ascertain whether therapeutic interventions promote the development of migratory and invasive tumor 462 cell phenotypes, we investigated the levels of CD271/NGFR of extensively treated 463 (BRAFi/MEKi and radiation or radiation and ICi) but progressive MBM. We observed high expression of CD271 (70-100\%) throughout the entire tumors (Fig. 1b, left panels and 
medRxiv preprint doi: https://doi.org/10.1101/2022.02.06.22270509; this version posted February 8, 2022. The copyright holder for this preprint (which was not certified by peer review) is the author/funder, who has granted medRxiv a license to display the preprint in perpetuity.

All rights reserved. No reuse allowed without permission.

465 Supplementary Fig. 1a) irrespective of therapeutic interventions, mutation status (BRAF, 466 NRAS) and intracranial location of MBM but potentially promoted by reactive astrocyte 467 secreted factors. The BRAF/NRAS mutation status of tumors was determined by TargetSeq 468 during routine diagnostic work-up. Whole transcriptome data of MBM prior and after 469 BRAFi/MEKi therapy are not available. Therefore, we investigated the levels of CD271 in a 470 set of drug-naïve, prior- (pre-relapse) treatment melanoma and tumors that relapsed after 471 dabrafenib/trametinib (GSE77940 ${ }^{70}$ ) treatment (post-relapse), (Fig. 1b, right panel). 472 CD271/NGFR was significantly (2.5fold, $p=0.034)$ increased in four of five post-treatment 473 tumors. Gene-set enrichment analysis (GSEA) revealed an invasive phenotype of post474 treatment tumors and a higher representation of signature genes indicating an 475 undifferentiated neural crest $(\mathrm{NC}) / \mathrm{NCSC}$-like (NES=2.953, FDR<0.001) or CD271/NGFR476 driven $(\mathrm{NES}=2.646$, FDR $<0.001)$ or invasive $\left(\mathrm{NES}=2.284, \mathrm{FDR}<0.001\right.$; Hoek signature ${ }^{56}$ ) 477 tumor cell state (Fig. 1c). Concordantly, we observed decreased levels of E-cadherin (CDH1, -0.212fold, $p=0.036$ ), (Supplementary Fig. 1b). Relapsing tumor cells featured enrichment of previously defined CD271-responsive genes (NES=2.646, $\mathrm{p}<0.001$ ) and a MAPKi-induced 480 EMT-like (NES=1.911, FDR<0.001) phenotype (Supplementary Fig. 1c). As we hypothesized 481 that CD271-driven programs mediate the progression of MBM by fostering the emergence of micrometastases, we investigated matched pre- and post-relapse tumors. We observed that CD271 ${ }^{+}$cells infiltrated the brain tumor environment, BTE (Fig. 1d, left panels) and formed micrometastases in close proximity to MBM/BTE transition sites (Fig. 1d, right panels).

Mechanisms of early brain development are conserved among vertebrates. However, recent single-cell sequencing studies of the developing human brain revealed spatial differences of 488 the cellular composition ${ }^{71}$. Hence, the response of tumors to environmental cues is likely determined by the cellular composition of environmental cells and secreted soluble factors, programing progression stages of MBM and primary brain tumors ${ }^{72}$. To identify molecular 491 subsets that potentially reveal the progressive state of MBM, we collected intraoperative and 492 cryo-preserved MBM ( $n=16$; Supplementary Table 1) from different intracranial sites (Fig. 2a) 
medRxiv preprint doi: https://doi.org/10.1101/2022.02.06.22270509; this version posted February 8, 2022. The copyright holder for this preprint (which was not certified by peer review) is the author/funder, who has granted medRxiv a license to display the preprint in perpetuity.

All rights reserved. No reuse allowed without permission.

493 including longitudinal metastases (Pat8) and patient matched pairs (patients 23, 24). The

494 latter synchronous metastases of patient 23 that developed within the occipital and parietal

495 lobes or MBM of patient 24 that emerged within the frontal lobe and lobus insularis, like

496 metastases of Pat8 (M2-M4) featured a therapy-resistant phenotype (Fig. 2a). Whole

497 transcriptome profiling of MBM and normal brain controls (Cortex, Pons, Cerebellum/Cereb;

498 BC; Supplementary Table 2) rather revealed a separation into subgroups regarding the

499 content of admixed brain parenchyma and irrespective of the intracranial region of tumors or

500 genetic state (presence of BRAF or NRAS mutations) (Fig. 2b). As resection of MBM usually

501 includes a margin of adjacent parenchymal cells, we determined the differentially regulated

502 genes (DEGs) among BC and MBM and identified a pan-gene signature potentially defining

503 MBM showing enrichment of extracellular exosomes and genes that are associated with

504 focal adhesion or defining extracellular matrix components (ECM) or melanosomes

505 (Supplementary Fig. 2a). Classifiers suggest a different distribution of molecular subsets

506 among the main subgroups such as the enrichment of classifiers of an NGFR ${ }^{\text {high }}$ or invasive

507 subset. Moreover, we observed a strong homogeneity of matched, synchronously resected

508 metastases of patient 23 and a clear separation of metachronous $(2018,2020)$, drug-

509 responsive or drug-resistant subclones M1 or M4 of Pat 8 . The initial TargetSeq of hot spot

510 regions of a panel of 50 cancer-associated genes provided information about the

511 BRAF/NRAS status of MBM $(n=37)$ and identified genetic aberrations in 11 genes among

512 them expected drivers of melanoma progression such as CDKN2A (Supplementary Fig. 2b-

513 c). Generally, we discovered that tumors were either BRAF or NRAS mutated.

514 Global methylome profiling serves as a tool for the comprehensive molecular classification of

515 several primary brain tumors ${ }^{73,74}$. We used $850 \mathrm{k}$ methylome profiling to gain insights into the

516 epigenetic landscapes of $\operatorname{MBM}(n=20)$ and to assess potential molecular subgroups.

517 Moreover, we asked for the similarity of concordant tumors that were synchronously resected

518 from different regions within the brain. The comparison of synchronous matched MBM

519 revealed a clear simultaneous clustering of occipital and parietal tumors of patient 23 (Fig.

520 2c), in concordance with whole transcriptome data. On the other hand, we observed a 
medRxiv preprint doi: https://doi.org/10.1101/2022.02.06.22270509; this version posted February 8, 2022. The copyright holder for this preprint (which was not certified by peer review) is the author/funder, who has granted medRxiv a license to display the preprint in perpetuity.

All rights reserved. No reuse allowed without permission.

521 divergent clustering of frontal and insular tumors of patient 24. Therefore, even though

522 matched tumors likely have synchronously evolved from a common founder clone during the

523 course of treatment and were simultaneously resected, MBM might follow very different

524 developmental routes. To exclude that the clustering was affected by admixed brain-derived

525 stromal cells, we calculated the tumor cell content based on the expression levels of PRAME

526 (Preferentially Expressed Antigen in Melanoma) observed in melanoma cell lines. PRAME

527 was coherently expressed in MBM (median: 79.8\%, range: 119.4-72.8\%) with one exception

528 (Pat 10) that showed no PRAME expression and was classified as primary central nervous

529 system (CNS) melanoma. PRAME was not expressed in brain-derived stromal cells and

530 several MBM exhibited even higher levels in comparison to melanoma cell lines

531 (Supplementary Fig. 3a, left panel).

532 Next, we wondered whether the subsets Ecad ${ }^{\text {high }}$ vs low, TIL $^{\text {high }}$ vs low and BRAF ${ }^{\text {mut }}$ vs wt 533 may be further classified by a set of differentially methylated genes (DMGs). We did indeed 534 find a significant (FDR-adjusted $p$-value $<0.05$ ) difference of $46 \mathrm{CpG}$ islands in promoters of 53535 genes that were hypomethylated in BRAF ${ }^{\text {mut }}$ tumors (Supplementary Fig. 3a, right panel).

536 The matching with transcriptome data revealed 14 MBM expressed genes that featured high 537 methylation of promoters in BRAF $^{\mathrm{wt}}$ tumors and identified integrin b7 (ITGB7) as a potential 538 predictor of favorable survival (Supplementary Fig. 3b-c).

The progression of MBM accompanies an E-cadherin-to-CD271 phenotype switch

540 Non-genetic processes such as cellular plasticity and phenotype switching are driving forces

541 of tumor heterogeneity and likely determine drug response and tumor relapse ${ }^{75}$. Several lines

542 of evidence suggest that therapeutic interventions blocking oncogenic BRAF (BRAFi/MEKi)

543 and/or inflammation-induced processes subsequently activate mechanisms driving invasive

544 and migratory properties of melanoma cells. These are associated with tumor relapse and

545 critical for the emergence of $M R D^{3,23,24,28,35,76,77}$. To gain insights into phenotypical and

546 molecular changes that occurred alongside progression, we investigated spatially separated,

547 longitudinal metastases of Pat8 that were collected before BRAFi/MEKi therapy (M1) or 
medRxiv preprint doi: https://doi.org/10.1101/2022.02.06.22270509; this version posted February 8, 2022. The copyright holder for this preprint (which was not certified by peer review) is the author/funder, who has granted medRxiv a license to display the preprint in perpetuity.

All rights reserved. No reuse allowed without permission.

548 which have developed and progressed under therapy (M2, M3, M4) (Fig. 3a). We observed a 549 high level of CD271 expression in M3 and M4 but a low level in pigmented subclones M1 and 550 M2 (Fig. 3b, left and center panels and Supplementary Fig. 4a). At the time of M4 resection, 551 the patient exhibited a very aggressive disease stage that was accompanied by meningeosis melanomatosa, the penetration of (HMB45 positive) melanoma cells into the CSF (Fig. 3c), suggesting that the emergence of CD271-driven subclones likely indicated a progressive 554 intracranial disease stage.

A comparative analysis of whole transcriptomes of M1 and M4 revealed a high concordance $(\mathrm{R}=0.85 ; \mathrm{p}<2.2 \mathrm{e}-16)$ and uncovered $\sim 1,000$ differentially regulated genes probably indicating different evolutionary traits of subclones (Supplementary Fig. 4b, Supplementary Table 3). Our survey identified decreased levels of E-cadherin (Ecad, 5fold) and of pigmentation markers (DCT, TYR, MLANA 7fold) and showed CD271/NGFR among the top upregulated genes in M4 ( 25fold). Presumably, the Ecad-to-CD271 phenotype switch marks a final step of MBM progression, which is rather a stepwise and slowly proceeding than a rapid process. We examined the levels of Ecad and CD271 in a lymph node metastasis (LN-MET) and concordant MBM (M1, M4) and validated co-occurrence of melanoma cells that featured

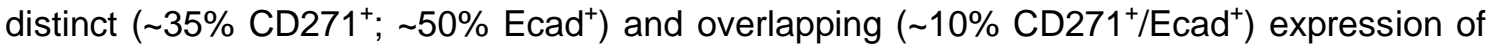
Ecad and CD271 in LN-MET (Fig. 3d, left panels and Supplementary Fig. 4c). Moreover, we observed distinct expression of both markers in M1 and M4 (Fig. 3d, right panels). CD271 ${ }^{+}$ cells were rarely found in Ecad ${ }^{+}$positive M1 (Supplementary Fig. 4d-e) and CD271 ${ }^{+} /$Ecad $^{+}$ cells that potentially reflected the plasticity-driven transition of Ecad ${ }^{+}$into $\mathrm{CD} 271^{+}$cells were not evident in M4. KBA.62 was used as a general marker of melanoma cells that enabled detection of stem-like CD271+ and non-stem-like melanoma cells of primary and metastatic melanoma ${ }^{78}$. Next, we sought for additional markers of invasive and progressive tumor cell phenotypes such as LOXL2 and CYR61 among the set of M1/M4 differentially regulated genes and observed a clear separation of both tumors regarding the gene expression levels

574 (Fig. 3e). Moreover, we applied gene signatures characteristic of CD271-dependent or 575 invasive programs and observed a significant higher median expression of CD271- 
medRxiv preprint doi: https://doi.org/10.1101/2022.02.06.22270509; this version posted February 8, 2022. The copyright holder for this preprint (which was not certified by peer review) is the author/funder, who has granted medRxiv a license to display the preprint in perpetuity.

All rights reserved. No reuse allowed without permission.

576 dependent $(p=2.7 e-05)$ and invasion-associated genes $(p=2.1 e-05)$ and a reduced

577 expression of pigmentation-associated markers ( $p=1 \mathrm{e}-02$ ) in M4 vs M1 (Fig. 3f). Ecad

578 expression in melanoma was associated with a proliferative and pigmented cell phenotype.

579 Thus, our findings strengthen the concept of a proliferative-to-invasive phenotype switch that

580 likely promotes MBM progression.

581

582 E-cadherin and CD271 define molecular subgroups of MBM

583 Ecad mediates the junctional connection of melanocytes and keratinocytes. The malignant 584 transformation of melanocytes to melanoma accompanies the downregulation of Ecad that imply a low level of Ecad expression in metastases. We identified Ecad among the top 1000 variably expressed genes in MBM and by the direct comparison of $B C$ vs $M B M(F C l o g 2=8.2$, 587 padj=0.012, Supplementary Table 2). Next, we analyzed for the frequency of Ecad- and CD271-expressing MBM and observed that 56.3\% (9/16) of MBM were Ecad positive. Levels of Ecad expression of another patient with meningeosis melanomatosa (Pat 11) and concordant pairs of pre- vs. post-relapse (Pat 19) and extracranial (spinal) vs. intracranial

591 (Pat 6) MBM (Fig. 4a) were comparable. The latter finding was confirmed by a comparison of whole transcriptome data $\left(E G A S 00001003672^{79}\right)$ of intracranial $(n=79, B M)$ and extracranial metastases $(n=59$, EM; $p=0.6144)$, (Supplementary Fig. 5a, left panel). Likely, brain metastatic tumor cells exhibit a rapid EMT-MET capacity and metastases re-acquire Ecad expression soon after every metastatic step. We surveyed the TCGA data set comprising primary melanoma (PT), EM and a rare subset of BM $(n=6)$ and observed lowest levels of

597 Ecad in EM (Supplementary Fig. 5a, right panel).

We ranked MBM regarding Ecad/CDH1 and NGFR levels (Supplementary Fig. 5b-d) and correlated genes, that are associated with either Ecad $(1,803$ genes, $p \leq 0.05)$ or NGFR $600(3,034$ genes, $p \leq 0.05)$ expression (Supplementary Table 4) and found an inverse association 601 of Ecad and NGFR correlated genes (Fig. 4b). The determination of DEGs among Ecad ${ }^{\text {high }}$ 602 and Ecad ${ }^{\text {low }}$ subgroups revealed CD271/NGFR and CRABP2 among the top expressed 603 genes in the Ecad ${ }^{\text {low }}$ (NGFR ${ }^{\text {high) }}$ tumors and SLC45A2, TSPAN10 and ABCC2 expressed by 
medRxiv preprint doi: https://doi.org/10.1101/2022.02.06.22270509; this version posted February 8, 2022. The copyright holder for this preprint (which was not certified by peer review) is the author/funder, who has granted medRxiv a license to display the preprint in perpetuity.

All rights reserved. No reuse allowed without permission.

604 Ecad ${ }^{\text {high }}$ tumors (Supplementary Table 4). Moreover, we validated that MITF-targets were 605 positively or negatively correlated with Ecad or NGFR/CD271 tumor cell subsets 606 (Supplementary Fig. 5e). Next, we determined the association of both molecular subsets $607 \mathrm{Ecad}^{+}$and $\mathrm{CD} 271^{+}$with BRAF mutation status. We validated the representation of gene signatures in MBM and observed that nearly all MBM with IHC-proven Ecad ${ }^{+}$or CD271 ${ }^{+}$ phenotypes featured expression of signature genes (Fig. 4c). We discovered a correlation of CD271/ Ecad expression, with BRAF status, suggesting that BRAF ${ }^{\mathrm{wt}} / \mathrm{NRAS}^{\text {mut }}$ MBM feature increased levels of NGFR/CD271 $(p=0.014)$ and BRAF ${ }^{\text {mut }}$ MBM are accompanied by Ecad expression ( $p=0.013$, Supplementary Fig. 6a). In addition, single sample GSEA (ssGSEA) revealed a correlation of CD271 $1^{\text {high }}$ MBM with brain metastasis in breast cancer $(p<0.05$, 614 Supplementary Fig. 6b-c, first panel) and validated the NGFR/p $75^{\mathrm{NTR}}$ dependency of CD271 $1^{\text {high }}$ tumors. served as a subset classifier of MBM (Fig. 4c). Generally, primary and secondary brain tumors are immunologically cold (non-inflamed) tumors ${ }^{80}$ and efficiently evade immune surveillance. Though a subset of MBM in our cohort $(n=8 ; 50 \%)$ showed infiltration of $\mathrm{CD}^{+} \mathrm{T}$ cells even discriminating M1 and M4 (Supplementary Fig. 6c, center, right panels) and clearly distinguished favorable ${ }^{81} \mathrm{TIL}^{\text {high }}$ and $\mathrm{TIL}^{\text {low }}$ subsets by expression levels of CD3D $(p=2.8 e-07)$ and CD8A ( $p=2.6 e-04$; Supplementary Fig. 6d). Moreover, TIL ${ }^{\text {high }}$ tumors featured increased inflammatory responses and activation of astrocytes (Supplementary Fig. $6 e)$, suggesting that inflammatory processes involving emergence of reactive astrocytes precede immune cell infiltration of tumors ${ }^{82}$. GSEA unraveled the molecular features of $\mathrm{Ecad}^{+}, \mathrm{CD}_{271^{+}}$or $\mathrm{TIL}^{\text {high }}$ tumors (Supplementary Table 5) and revealed a proliferative phenotype (Hoek_Proliferative, NES $=3.335$, FDR<0.001) of Ecad $^{\text {pos }}$ tumor cells. Ecad $^{\text {low }} /$ CD271 $1^{\text {high }}$ tumors featured enrichment of a tumor-intrinsic NGFR signature that was derived from a set of melanoma cell lines which had spontaneously acquired resistance to $\mathrm{T}$ 630 cells (Boshuizen_NGFR ${ }^{\text {high }}$ UP, NES=2.634, FDR<0.001). The signature potentially predicts 631 anti-PD-1 therapy resistance, and increased immune exclusion. Moreover, Ecad ${ }^{\text {low }} /$ CD271 ${ }^{\text {high }}$ 
medRxiv preprint doi: https://doi.org/10.1101/2022.02.06.22270509; this version posted February 8, 2022. The copyright holder for this preprint (which was not certified by peer review) is the author/funder, who has granted medRxiv a license to display the preprint in perpetuity.

All rights reserved. No reuse allowed without permission.

632 MBM exhibited an invasive phenotype (Hoek_Invasive, NES $=2.318$, FDR<0.001) among

633 other core enrichments (Fig. 4d and Supplementary Table 5).

634

635 Hence, although the emergence of MBM is generally associated with poor prognosis, the 636 different phenotypes might determine the degree of aggressiveness of intracerebral tumors 637 and their capability of formation of multiple brain metastases and response to therapeutic 638 interventions.

\section{MBM-derived cell lines reflected and maintained tumor-cell properties}

641 The mutual interaction of MBM cells with components of the brain microenvironment such as growth factors, chemokines and extracellular matrix (ECM) proteins probably has a strong impact on disease progression. Very recently, the release of CD271-carrying extracellular vesicles was recognized as a critical step in lymphangiogenesis and metastasis ${ }^{37}$. Moreover, neurotrophins such as NGF and BDNF that are released by reactive astrocytes likely induce a migratory and invasive phenotype of $\mathrm{MBM}^{83}$. Besides the supportive function of the tumor micronenvironment for the establishment and progression of MBM, we wondered whether the progressive state of MBM cells is maintained by in vitro conditions. Therefore, we established a panel of stable cell lines from intraoperative MBM of patients that had not (BMC1-M1, BMC2) or had received (BMC1-M4, BMC4) BRAFi/MEKi or ICi therapies. Intraoperative MBM from different brain regions were minced and enzymatically digested to obtain a single cell suspension that predominantly contained tumor cells but also admixed environmental cells such as astrocytes, microglia and oligodendrocytes (Fig. 5a, $1^{\circ}$ ). The passaging of $1^{\circ}$ cells subsequently enriched for tumor cells that adapted to the in vitro conditions. All patients exhibited multiple BM at the time of operation; hence, we expected MBM-derived tumor cells to feature a high migratory and invasive phenotype, which generally have been associated with the expression of markers such as AXL, MET and 
medRxiv preprint doi: https://doi.org/10.1101/2022.02.06.22270509; this version posted February 8, 2022. The copyright holder for this preprint (which was not certified by peer review) is the author/funder, who has granted medRxiv a license to display the preprint in perpetuity.

All rights reserved. No reuse allowed without permission.

660 CD271 was highly expressed in adherently growing BMCs and associated suspension cells

661 (Figs. 5b; 5c, right panels and Supplementary Fig. 7a-b). The majority $(3 / 5 ; 60 \%)$ of BMCs 662 featured a suspension phenotype that was likely related to a high CD271 level ${ }^{84}$ and associated mutations. High levels of AXL had been attributed conferring a migratory and invasive phenotype to melanoma ${ }^{85}$. We detected a significantly higher $\mathrm{AXL}$ expression in MBM than BC (Supplementary Fig. 7c), validated in a subset of $\mathrm{AXL}^{+} \mathrm{MBM}$ and $\mathrm{BMC1}-\mathrm{M} 1$ cells (Supplementary Fig. 7d). However, we found a discordant pattern of expression of AXL and its ligand GAS6 in MBM (not shown) and rarely observed activation/ phosphorylation of AXL (Supplementary Fig. 7e).

In response to BRAFi/MEKi, melanoma cells perform phenotype switching, a non-genetic process during which cells convert from a proliferative to an invasive and drug-resistant state $^{86,87}$. Our previous data suggested that the proliferative and pigmented tumor cell state was represented by Ecad expression, while the migratory and invasive phenotype was characterized by expression of CD271/NGFR. Accordingly, Ecad/CD271 double positive cells seem to indicate tumor cells in the transitory state. We discovered a proliferative phenotype of the progressive tumor M4 $\left(61.0 \pm 11.0 \% \mathrm{Ki} 67^{+}\right.$cells) and a lower and highly variable level of proliferative cells in M1 $\left(17.1 \pm 12.3 \% \mathrm{Ki} 67^{+}\right.$cells, Supplementary Fig. 8a, left panel). This finding was also reflected by Ki67 levels (BMC1-M1, 48.1 $7.0 \%$; BMC1-M4,

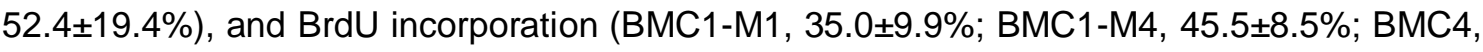
$25.5 \pm 6.2 \%$ ) of the corresponding BMCs (Supplementary Fig. 8a, right panel). Next, we assessed the migratory capacity of BMCs by a live-cell imaging-based scratch-wound assay. We observed a high migratory capacity as indicted by a rapid wound closure by BMC1-M4 $(669.2 \pm 42.8-2.4 \pm 4.1 \mu \mathrm{m})$, BMC2 $(515.9 \pm 52.0-11.4 \pm 10.5 \mu \mathrm{m})$ and BMC4 $(567.4 \pm 70.5-$ $5.8 \pm 10.0 \mu \mathrm{m})$ but a lower capacity of BMC1-M1 cells $(709.2 \pm 9.3-168.1 .4 \pm 41.1 \mu \mathrm{m})$, $\mathrm{p}(\mathrm{BMC1}-\mathrm{M} 1$ vs BMC1-M4) $=0.004$ (Supplementary Fig. 8b-c). The capability of spheroid formation of melanoma cells is associated with stemness that in turn is connected with a migratory and invasive phenotype ${ }^{88,89}$. To ascertain the spheroid-forming capacity of BMCs, we seeded 2.5 $\times 10^{3}$ BMC1-M1 and BMC1-M4 cells onto a layer of matrigel, which enabled 
medRxiv preprint doi: https://doi.org/10.1101/2022.02.06.22270509; this version posted February 8, 2022. The copyright holder for this preprint (which was not certified by peer review) is the author/funder, who has granted medRxiv a license to display the preprint in perpetuity.

All rights reserved. No reuse allowed without permission.

spheroid formation following invasion of the matrigel layer. BMC1-M4 cells formed loosely connected three-dimensional (3D) colonies and satellite colonies (Fig. 5d, upper panels) whereas BMC1-M1 established colonies featured a non-scattered phenotype (Fig. 5d, lower panels). Although this assay reflected an interaction of tumor cells with extracellular matrix forming collagens and laminins, tumor cells might feature different phenotypes in response to a brain-associated microenvironment that is build up by astrocytes and microglia among others. The stronger migratory capacity and 3D satellite-growth pattern of BMC1-M4 cells suggest a higher progressive phenotype compared to BMC1-M1 cells. To assess whether "tumor naïve", normal brain cells were capable of repressing the progressive state of BMC1M4 cells, we injected $2.5 \times 10^{4}$ cells of both cell lines into the right hemispheres of CD-1 nude mice ( $n=3$ per group) and weakly tracked tumor formation via MRI for a period of 49 days (Fig. 5e). BMC1-M4 cells established detectable tumors (median volume of $11.77 \mathrm{~mm}^{3}(\mathrm{n}=3$; range: $3-17 \mathrm{~mm}^{3}$ ) 14 days post injection (range $7-14 \mathrm{~d}$ ) that featured a constant growth and reached a median volume of $23.35 \mathrm{~mm}^{3}$ (range 22-30 $\mathrm{mm}^{3}$ ) after 21d. In contrast, BMC1-M1 cells indeed featured a less progressive phenotype and established small size tumors (maximum volume: $2.705 \mathrm{~mm}^{3} ; \mathrm{n}=2$ ) $35 \mathrm{~d}$ after injection (Supplementary Fig. 8d-e). Therefore, the progressive phenotype of BMC1-M4 cells and distinct growth properties of both cell lines were maintained in vivo and potentially controlled by intrinsic cues.

\section{Genetic profiling of longitudinal MBM and BMCs revealed a high genetic concordance} and validated subclonal stability

Non-genetic molecular programs such as those controlling the MITF/AXL proliferative/invasive switch, drive tumor heterogeneity and establish MRD, a crucial driver of metastatic progression ${ }^{35,90}$. MRD and high migratory phenotypes of melanoma cells were correlated with the expression of CD271 and observed in BMCs and in a subset but not all tumors of our MBM cohort. As BMCs were expected to serve as in vitro models that reflect tumor cell phenotypes, we asked for the comparability of MBM and BMCs. The comparison of whole transcriptomes of MBM and low-passage (p1-p5) MBM-derived cell lines revealed a high concordance of $\mathrm{M} 1$ and $\mathrm{BMC1}-\mathrm{M} 1(\mathrm{R}=0.89, \mathrm{p}<2.2 \mathrm{e}-16)$ and $\mathrm{M} 4$ and $\mathrm{BMC} 1-\mathrm{M} 4(\mathrm{R}=0.90$, 
medRxiv preprint doi: https://doi.org/10.1101/2022.02.06.22270509; this version posted February 8, 2022. The copyright holder for this preprint (which was not certified by peer review) is the author/funder, who has granted medRxiv a license to display the preprint in perpetuity.

All rights reserved. No reuse allowed without permission.

$716 \mathrm{p}<2.2 \mathrm{e}-16)$, (Fig. 6a). Moreover, total levels of CD271 reflected the migratory capacity of all

717 BMCs except from BMC4 (Supplementary Fig. 9a). As extracranial and intracranial

718 metastases show comparable molecular characteristics ${ }^{91}$, we further investigated whether

719 BMCs were molecularly distinct from conventional cell lines (A375, MeWo) or a patient-

720 derived cell line that was established from a LN-MET (T2002). In principle, the intracranial

721 injection of $1 \times 10^{3}$ A375 cells into NSG mice gave rise to tumors within 25d (Supplementary

722 Fig. 9b), hence this cell line was capable of adaptation to the foreign microenvironment and

723 undergoing an in vitro to in vivo switch. A correlation of MBM, BMCs, BCs, conventional cell

724 lines (A375, MeWo), T2002 and melanocytes based on whole transcriptome data revealed

725 that BMCs clustered with the concordant tumors but not with A375, MeWo or T2002 cells

726 (Supplementary Fig. 9c). Hence, BMCs maintained molecular programs that were distinct

727 from conventional cell lines.

728 To exclude that MBM-derived cell lines underwent genetic changes triggered by the 729 adaptation to in vitro conditions, we performed TargetSeq of longitudinal MBM, BMCs of 730 patient's 8,35 and 27 and CSF of Pat8 with a mean coverage of $760 x$ (range 290x-1,505x).

731 TargetSeq provided insights into the permanence of hotspot regions of 560 cancer-related 732 genes and enabled tracing of genetic subclones. The latter potentially emerged during the 733 course of disease in response to therapeutic interventions and microenvironmental changes.

734 We identified 18 ground-state mutations that were commonly found in all specimens of Pat8, 735 particularly $\mathrm{BRAF}^{\mathrm{V} 600 \mathrm{E}}$ and $\mathrm{RAC1}{ }^{\mathrm{P} 29 \mathrm{~S}}$, which are known genetic drivers of cancer 736 progression ${ }^{92-95}$. Mutations in RAC1 present early UV-radiation caused aberrations, 737 potentially driving BRAFi-resistance, membrane ruffling (Supplementary Fig. 9d) and cell 738 migration $^{94,96}$. In addition, we identified likely deleterious but functionally uncharacterized 739 mutations in CARD11 and MYC (CARD11 ${ }^{\text {D56N; }}$ COSV62717671 and MYC ${ }^{\mathrm{N} 265}$; 740 COSV52371145) that have been associated with cancer $^{97}$ (Fig. 6b and Supplementary Fig. 741 10a). Apart from public mutations, we detected missense and nonsense mutations, which 742 were exclusively found in either of the longitudinal tumors (Fig. 6b and Supplementary Fig. 743 10a). These private mutations were persistent; hence, subclones carrying a certain mutation 
medRxiv preprint doi: https://doi.org/10.1101/2022.02.06.22270509; this version posted February 8, 2022. The copyright holder for this preprint (which was not certified by peer review) is the author/funder, who has granted medRxiv a license to display the preprint in perpetuity.

All rights reserved. No reuse allowed without permission.

such as FGFR4 ${ }^{\mathrm{S} 431 S}$ were maintained in vitro. In addition, we observed that subclones bearing NAB2 ${ }^{\mathrm{G} 221 \mathrm{~W}}$ mutations were outcompeted or acquired during final steps of progression such as a MAPK (MAP3K $1^{\mathrm{E} 224 \mathrm{X}}$ ) mutation that potentially fostered the emergence of highly aggressive subclones. Presumably, the latter are capable of transitioning into the subarachnoid space and survive in the CSF. The comparative analysis of MBM and BMCs of patients 8, 27 and 35 validated a high genetic concordance (M1 vs BMC1-M1; 99.2\%/ M4 vs BMC1-M4; 97.4\%/ Pat 35 vs BMC2; 51.9\%/ Pat 27 vs BMC3; 51.5\%). Besides class I mutations, we discovered subclones carrying a class III BRAF mutation (BRAF ${ }^{\mathrm{N} 581 \mathrm{Y}}$ ) that were maintained in the tumor (Pat35) and in vitro (BMC2) next to NRAS ${ }^{\mathrm{G} 12 \mathrm{C}}$ mutant clones. Moreover, we identified a minor subclone in Pat8/M4 carrying a probably damaging lowfrequent $\mathrm{NOTCH} 3^{\mathrm{S1128P}}$ mutation $(\mathrm{AF}=0.03)$, (Supplementary Fig. 10b) that was maintained by in vitro cell culture conditions (BMC1-M4, AF=0.46; Supplementary Fig. 10c, Supplementary Table 6). Overall, these results suggest that the general composition of genetic subclones was not affected by the in vivo-to in vitro transition. Nonetheless, a minority of clones that was suppressed in vivo emerged in vitro.

\section{BMCs exhibited unique responses towards therapeutic drugs}

The development of progressive intracranial disease is frequently observed in melanoma patients and the consequence of drug resistance. Next, we ascertained whether and to which extent the drug resistance conferring mechanisms of patient's tumors were conserved in BMCs. Patient's 8/M4 and 38 exhibited mutations in BRAF (BRAF $\left.{ }^{\mathrm{V} 600 \mathrm{~K}} ; A F=0.91\right)$ and $\mathrm{RAC} 1$ $\left(\mathrm{RAC1}{ }^{\mathrm{P} 29 \mathrm{~S}} ; \mathrm{AF}=0.36\right)$ but lacked resistance-mediating secondary mutations in BRAF or acquired mutations in MEK $1^{98}$ or NRAS ${ }^{99}$. We tested the sensitivity of BMCs towards low $(1 \mathrm{nM}-10 \mathrm{nM})$ and high doses $(30 \mathrm{nM}-10 \mu \mathrm{M})$ of dabrafenib, one of the first-line modalities for patients with BRAF ${ }^{\mathrm{V} 600 \mathrm{E} / \mathrm{K}} \mathrm{MBM}$. As expected, TargetSeq and pyrosequencing (Fig. 6b, Supplementary Fig. 10d) confirmed the persistence of BRAF ${ }^{\mathrm{V} 600 \mathrm{E} / \mathrm{K}}$ mutated tumor cells in vitro. Remarkably, BMC1-M4 cells showed a significant response to low doses (3nM, 10nM) of dabrafenib ( $\left.\mathrm{IC}_{50}=7.65 \mathrm{nM}\right)$. In contrast, BMC1-M1 cells originating from a drug-naïve tumor 
medRxiv preprint doi: https://doi.org/10.1101/2022.02.06.22270509; this version posted February 8, 2022. The copyright holder for this preprint (which was not certified by peer review) is the author/funder, who has granted medRxiv a license to display the preprint in perpetuity.

All rights reserved. No reuse allowed without permission.

772 were refractory to low doses $\left(\mathrm{IC}_{50}=224.4 \mathrm{nM}\right)$ of dabrafenib (Fig. 6c, first and second panel).

773 This finding likely reflected the loss of resistance at least partly due to the switch from BRAFi

774 to $\mathrm{ICi}$ in the therapeutic course of Pat8. BMC4 cells were refractory to low doses of 775 dabrafenib $\left(\mathrm{IC}_{50}=47.72 \mathrm{nM}\right)$ (Fig. 6c, third panel and Supplementary Fig. 11a). Congruently, 776 BMC2 cells carrying a BRAF ${ }^{\mathrm{N} 581 Y}$ mutation showed no response to dabrafenib 777 (Supplementary Fig. 11b, left panel). Although previous studies suggested that the expression of NGFR/CD271 drives resistance to $\mathrm{BRAFi}^{77,100}$, we observed no correlation of CD271/NGFR levels with response to dabrafenib.

The evolution of BRAFi/MEKi therapy-resistant genetic subclones that hamper drug response and consequentially drive metastatic progression is frequently observed in melanoma patients. Although chemotherapeutics show limited efficacy in disseminated melanoma and are mostly applied for palliative care, they might be effective in BRAFi- or ICiresistant tumors. We assessed the efficacy of paclitaxel, an actin filament interfering drug in BMCs that exhibited a low response towards dabrafenib. Paclitaxel was effective in intrinsic dabrafenib-resistant BMC4 cells $\left(\mathrm{IC}_{50}=153.3 \mathrm{pM}\right)$ or less-sensitive BMC1-M1 cells $\left(\mathrm{IC}_{50}=114.5\right.$ pM, Fig. $6 \mathrm{~d}$, first and second panels, Supplementary Fig. 11b, right panel). In addition, the frequent expression of the MET receptor tyrosine kinase in BM of lung and breast cancer suggests a clinical relevance of small molecular inhibitors of MET for the treatment of $\mathrm{BM}^{101,102}$. We discovered that the MET receptor was among the Ecad ${ }^{\text {high }}$ subset enriched genes (FClog2 $=2.1, \mathrm{p}=3 \mathrm{e}-03$ ) and significantly higher expressed in MBM than EM ( $p=2.7 e-05$; Supplementary Fig. 12a, left and center panels). Moreover, MET expression was significantly higher in the Ecad ${ }^{\text {high }}$ subset of $\operatorname{MBM}(n=43, p=1.4 e-04$, two-way anova) than EM $(\mathrm{n}=50, \mathrm{p}=0.41$; Supplementary Fig. $12 \mathrm{a}$, right panel). We evaluated the expression and activation of MET in MBM and observed activated MET signaling (phosphorylation at Tyr1234/1235, p-MET $^{\text {Tyr1234/1235) }}$ in a subset of tumors (Supplementary Fig. 12b, upper panels). Fluorescence in-situ hybridization revealed that MET expression was not linked to gene amplification (Supplementary Fig. 12b, lower panel and 12c upper panel). In addition, 
medRxiv preprint doi: https://doi.org/10.1101/2022.02.06.22270509; this version posted February 8, 2022. The copyright holder for this preprint (which was not certified by peer review) is the author/funder, who has granted medRxiv a license to display the preprint in perpetuity.

All rights reserved. No reuse allowed without permission.

800 signaling is a well-known driver of cell migration and associated with activity of small Ras-

801 related GTPases such as RAC1 which in turn trigger the formation of cortical actin-containing

802 membrane ruffles and lamellopodia ${ }^{103-105}$. The expression of MET was maintained in BMCs

803 and localized at membranes including ruffles (Supplementary Fig. 12c, lower panels).

804 Therefore, we expected that highly migratory cells are sensitive to the non-ATP competitive

805 MET-inhibitor tivantinib (ARQ197), which has been clinically approved for hepatocellular

806 carcinoma (NCT01755767) and lung cancer (NCT01395758) among other non-melanoma

807 related studies. We discovered that BMCs responded to ARQ197 (BMC1-M1: $I_{50}=351.8$

$808 \mathrm{nM}$; BMC1-M4: IC ${ }_{50}=376.1 \mathrm{nM}$; BMC2: IC ${ }_{50}=596.3 \mathrm{nM}$; BMC4: IC ${ }_{50}=291.4 \mathrm{nM}$ ) irrespective

809 of the degree of dabrafenib response. However, we observed a higher sensitivity in

810 conventional melanoma cell lines $\left(A 375: I_{50}=200.8 \mathrm{nM}, A 2058: I_{50}=242.2 \mathrm{nM}\right.$ and MeWo:

$811 \quad I_{50}=106.1 \mathrm{nM}$; Fig. 6d-e, Supplementary Fig. 12d).

812 Taken together, the comparative analysis of Iongitudinal MBM and concordant cell lines

813 provided insight into the persistence and stability of genetic subclones and suggests that low-

814 passage BMCs reflect the genetic landscape of tumors and serve as in vitro model systems.

815

816 The loss of Ecad expression recapitulates steps of in vivo progression

817 Supposedly, the first metastatic dissemination to local sites such as regional lymph nodes

818 selects for a subset of cells establishing the metastatic cascade. A prerequisite for the latter

819 process is the survival of circulating cells in the blood stream and lymphatic vessels and the 820 capability of adaptation to microenvironmental cues, prevailing at distant organ sites ${ }^{106}$. Like

821 extracellular niches, the intracerebral tumor cell niche is built up by stromal cells such as 822 astrocytes, microglia and infiltrating immune cells (Fig. 7a, "in vivo") that release growth 823 factors and exosomes in response to their interaction with tumor cells. Although we observed 824 an overall concordance of MBM and BMCs, the derivation of BMC1-M1 cells (Fig. 7a, "in 825 vitro"), was accompanied by differential expression of 362 genes ( $p=5.3 e-04)$, which was 826 likely triggered by the in vivo-to-in vitro switch (Fig. 7b). Particularly, we found a loss of the 
medRxiv preprint doi: https://doi.org/10.1101/2022.02.06.22270509; this version posted February 8, 2022. The copyright holder for this preprint (which was not certified by peer review) is the author/funder, who has granted medRxiv a license to display the preprint in perpetuity.

All rights reserved. No reuse allowed without permission.

827 Ecad $^{+}$state (Fig. 7c, left panel) of the initial tumor (M1; FClog2=-6.775, p=6.41E-05).

828 Nevertheless, a minor Ecad ${ }^{+}$subfraction was maintained in vitro (Fig. 7c, right panels), in line 829 with previous findings suggesting that Ecad expression is unstable in cell lines ${ }^{107}$. Next, we 830 sought whether the in vitro loss of Ecad ${ }^{+}$cells reflected mechanisms of in vivo progression, 831 hence the derivation of the therapy-resistant subclone M4 from M1. Comparative analysis of 832 whole transcriptome data of Pat 8/M1 vs. M4 and their respective tumor-derived cell lines 833 (BMC1-M1; BMC1-M4) revealed a clear proliferative-to-invasive switch of MBM cells but 834 concordance of M4 and BMC1-M4 cells (Fig. 7d). Apart from NGFR, we focused on 835 differentially regulated transcription factors in our survey and identified significantly 836 decreased levels of STAT5A (FClog2 $=-2.468, p=3.88 e-02$ ) and MITF (FClog2 $=-2.840$, $837 \mathrm{p}=2.16 \mathrm{e}-02$ ) in early and late passage BMC1-M1 cells. Levels of FOSL1 (FClog2=8.145, $838 p=1.39 \mathrm{e}-05)$, FOSL2 (FClog2 $=3.277, p=1.29 \mathrm{e}-02)$ and POU3F2 (FClog2 $=3.280, p=1.36 e-02)$ expression were increased. Likely, the latter factors are responsible for the activation and maintenance of cell autonomous, hence niche-independent programs. We hypothesized that both the emergence of progressive subclones such as M4 and the in vitro transition of M1

842 cells were driven by a comparable set of molecular programs and likely triggered by changes 843 of niche-provided factors. The comparative analysis of genes differentially regulated between M1 vs. BMC1-M1 and M1 vs. M4 revealed a common set of 100 (termed "progressive") genes that promoted the conversion of Ecad ${ }^{+}$into $\mathrm{CD} 271^{+}$MBM cells in vivo and in vitro (Fig. 7d, right panel) among them NGFR, FOSL1 and FOSL2 (Supplementary Table 7). As 847 STAT5A has been associated with Ecad expression ${ }^{108}$, we surveyed the correlation of 848 STAT5A and Ecad in MBM and extracranial metastases of melanoma (TCGA-MM). STAT5A 849 but not STAT5B was correlated with Ecad expression in MBM $(R=0.837 ; p=1.00 e-04$, Fig. 7e 850 and Supplementary Fig. 13a, left panel) and among the upregulated genes (FClog2=1.581, $851 \mathrm{p}=1.04 \mathrm{E}-05)$ in the Ecad ${ }^{\text {high }}$ subset. In addition, STAT5A was expressed in a subset of 852 Ecad $^{\text {high }}$ extracranial metastases ( $n=315$, EM; $p=2 e-04$, Fig. 7e) but not in brain metastases $853(n=6, B M)$ or primary tumors $(n=151$, PT) of TCGA-MM. FOSL1 was correlated with the 854 CD271 status of TCGA-MM (EM, PT; Supplementary Fig. 13a, right panel), however FOSL 
medRxiv preprint doi: https://doi.org/10.1101/2022.02.06.22270509; this version posted February 8, 2022. The copyright holder for this preprint (which was not certified by peer review) is the author/funder, who has granted medRxiv a license to display the preprint in perpetuity.

All rights reserved. No reuse allowed without permission.

expression was not associated with CD271/NGFR expression in MBM (Supplementary Table

856 4). Next, we assessed the distribution and activation of STAT5A and expression levels of

857 Ecad in CD271 ${ }^{\text {high }}$ and low MBM.

858 Immunohistochemistry analysis for Ecad and total STAT5A revealed that even CD271 ${ }^{\text {high }}$

859 tumors such as M4 comprised Ecad ${ }^{+}$cells that were likely maintained in progressive tumors

860 and not converted into $\mathrm{CD} 271^{+}$cells reflecting at least two different co-existing cellular stages

861 (Supplementary Fig. 13b, upper scheme). Ecad ${ }^{+}$expressing cells exhibited activated

862 STAT5A signaling, hence nuclear STAT5A and a reduced infiltration into adjacent tissue

863 (Fig. 7f, left panels). Moreover, we identified a decreased nuclear localization or expression

864 of STAT5A at epithelial-like into mesenchymal-like transition sites (Fig. $7 f$, right panels).

865 However, intersecting areas of Ecad $^{\text {neg }} /$ STAT5A $^{+}$and Ecad $^{+} /$STAT5A ${ }^{\text {neg }}$ tumor cells

866 suggested that STAT5A activation was required but probably not sufficient for driving Ecad

867 expression. Considering the high plasticity of melanoma cells, Ecad and CD271 are likely

868 interconnected. To address whether $\mathrm{Ecad}^{+}$evolved from $\mathrm{CD} 271^{+}$cells or vice versa

869 (Supplementary Fig. 13b, upper scheme), we established a transcriptional dual-reporter

system facilitating the tracing of the Ecad ${ }^{+}$subset via Ecad promoter-controlled expression of

871 RFP. We monitored the NGFR/CD271 subset via a $3^{\prime}$-UTR-GFP reporter that enabled the

872 detection of NGFR-mRNA stability (Supplementary Fig. 13b, lower scheme) ${ }^{34,109,110}$. The

873 additional constitutive expression of iRFP enabled the general labeling of reporter cells

874 independent from phenotype switching processes (Supplementary Fig. 13c, upper panels).

875 As CD271/NGFR-GFP ${ }^{+}$cells are generally sustained in vitro ${ }^{109}$, we traced FACS-enriched

876 RFP/iRFP cells (Supplementary Fig. 13c, lower panels). The initial (100\%) Ecad ${ }^{+}$fraction

877 was decreased by $38.9 \pm 13.6 \% \quad(p \leq 0.01) 2$ days after the FACS-based isolation

878 (Supplementary Fig. 13d), suggesting that Ecad ${ }^{+}$subsets are unstable and not sustained by

879 standard 2D in vitro conditions. However, live cell-imaging revealed rare $(<0.1 \%)$ derivation

880 of Ecad $^{\mathrm{RFP}+}$ cells from NGFR ${ }^{\mathrm{GFP}+}$ (Supplementary Fig. 13e and movies 1 and 2), or double

881 negative cells. 
medRxiv preprint doi: https://doi.org/10.1101/2022.02.06.22270509; this version posted February 8, 2022. The copyright holder for this preprint (which was not certified by peer review) is the author/funder, who has granted medRxiv a license to display the preprint in perpetuity.

All rights reserved. No reuse allowed without permission.

882 Next, we investigated whether forced STAT5A expression was sufficient to restore Ecad 883 expression and increased the $\mathrm{Ecad}^{+}$subset in BMCs. Therefore, BMC4 cells were 884 transduced with wildtype (STAT5A $\left.{ }^{\text {wt-GFP }}\right)$, mutant $\left(\right.$ STAT5A $\left.A^{\text {S710F-GFP }}\right)$ STAT5A or empty control 885 plasmids (Supplementary Fig. 14a, left panels). STAT5A ${ }^{\text {S710F-GFP }}$ represents a constitutive 886 active form with enhanced tetramer forming capacity ${ }^{111}$. We observed a marginal but 887 significantly increased number of Ecad/DECMA $1^{+}$cells in STAT5A ${ }^{\text {S710F-GFP }}(3.6 \pm 0.8 \%$, $888 \mathrm{p}=0.053)$ but not in STAT5A ${ }^{\mathrm{wt}-G F P}(1.4 \pm 0.3 \%)$ or control cells $(1.6 \pm 0.6 \%$; Supplementary Fig. $88914 a$, right panel), suggesting that STAT5A activation might be required but was not sufficient to generate or maintain an Ecad ${ }^{+}$cell phenotype.

CD271 cooperates with a network of progressive-genes to mediate cell migration and invasion

893 Considering that CD271 controls cell migration and MBM progression, we performed whole 894 transcriptome profiling of BMC1-M1 with a highly efficient inducible knockdown of NGFR. We

895

896 tested the functional reliability of shRNA in conventional (A375, WM35) and MBM-derived cell lines 7-14 days after doxycycline (DOX)-treatment (Supplementary Fig. 15a). We

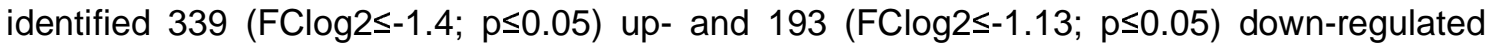
genes in BMC1-M1. Moreover, we identified 125 CD271-dependent genes that were commonly downregulated in BMC1-M1 cells and in a lymph node metastasis-derived cell line (T2002, GSE52456, Supplementary Fig. 15b). Among them were SOX4, a master-regulator of $\mathrm{EMT}^{112,113}$ and PTPRZ1 a mediator of stemness in glioblastoma ${ }^{114}$. As both cell lines were unrelated and comprised different sets of mutations (T2002, BRAF/NRAS ${ }^{\mathrm{wt}}$; BMC1-M1, $\mathrm{BRAF}^{\mathrm{V} 600 \mathrm{E}}$ ), the $\mathrm{CD} 271$-associated regulation of genes was probably context independent. The EMT-promoting transcription factor SOX4 (FClog2=-2.9; $p=1.1 \mathrm{E}-17$, Supplementary Table 8) was among the most significantly downregulated genes in BMC1-M1 and T2002 cells.

The expression of CD271 was correlated with a suspension phenotype of melanoma cells ${ }^{84}$ that was frequently observed in BMCs. Suspension cells (SCs) were viable and their serial reseeding established adherently growing $\mathrm{CD} 271^{+}$cells (Fig. 8a, upper panel) which in turn 
medRxiv preprint doi: https://doi.org/10.1101/2022.02.06.22270509; this version posted February 8, 2022. The copyright holder for this preprint (which was not certified by peer review) is the author/funder, who has granted medRxiv a license to display the preprint in perpetuity.

All rights reserved. No reuse allowed without permission.

910 subsequently shed suspension cells. The phenotype was more evident in BMC1-M4

$911(10.3 \pm 0.7 \%)$ than in BMC1-M1 (3.6 $\pm 2.2 \%)$ cells (Fig. 8a, lower panel) and was significantly

912 reduced $(3.3 \pm 1.8 \%, p=0.013)$ by the knockdown of CD271 (Fig. 8a, lower panel).

913 Following, we assessed whether the modulation of CD271 levels affected invasion and 3D-

914 spheroid formation. We then seeded $2.5 \times 10^{3}$ cells of either control cells (-DOX) or cells with

915 a validated knockdown of CD271 (+DOX) on a matrigel layer (Fig. 8b, left scheme). Control

916 cells invaded the matrigel layer and formed spheroids after $\sim 7$ days that in turn shed cells

917 into the matrigel (Fig. 8b, left panels). The concomitant expression of GFP (Fig. 8b, right

918 panels; inlaid) enabled the tracing of cells upon DOX induction (Fig. 8b, right panels).

919 Downregulation of NGFR expression significantly $(p=3.4 e-12)$ reduced the diameter of

920 spheroids (Fig. 8c, upper panel, Supplementary Fig. 15c) and affected the two-dimensional

921 growth (Fig. 8c, lower panel). A minority of cells that likely featured a highly invasive

922 phenotype completely crossed the matrigel layer and attached to the vessel's bottom (Fig.

923 8d). This process was not observed upon NGFR knockdown. Finally, we assessed whether

924 decreased expression of CD271 was sufficient for hampering migratory processes of BMCs.

925 The migratory phenotype of BMC1-M1 and BMC2 cells, both featuring different types of

926 BRAF mutations was significantly reduced upon NGFR downregulation with no obvious

927 difference in the extent of inhibition (Fig. 8e, left panel, Supplementary Fig. 15d). In line, we

928 observed reduced levels of drivers of EMT/ cell migration such as SOX4 ${ }^{115}$, MET receptor

$929(\mathrm{MET})^{116}$, and TCF19 $9^{117}$ and increased expression of AXL (Fig. 8e, center panel) in CD271

930 knockdown cells. SOX4 likely acts as a master regulator of EMT ${ }^{118}$ and was expressed in all

931 MBM investigated (FClog2=4.44 \pm 0.97 ; range: $2.6-6.3$ ) but expressed at lower levels in $B C$

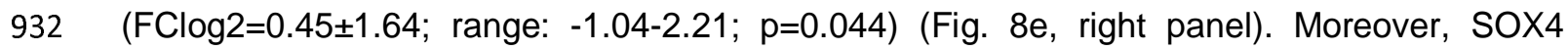

933 expression levels were comparable in primary and metastatic melanoma (TCGA set; data not

934 shown) and sustained in BMCs (Fig. 8f, upper panel) suggesting a general role of SOX4 in

935 the maintenance of melanoma cells in vivo and in vitro. To dissect the role of SOX4, we

936 performed a SOX4 knockdown in BMC1-M4 and BMC4 cells and tracked changes in

937 proliferation of knockdown (+DOX) and control cells (-DOX) via live-cell imaging for 5 days 
medRxiv preprint doi: https://doi.org/10.1101/2022.02.06.22270509; this version posted February 8, 2022. The copyright holder for this preprint (which was not certified by peer review) is the author/funder, who has granted medRxiv a license to display the preprint in perpetuity.

All rights reserved. No reuse allowed without permission.

938 (Fig. 8f, scheme). We observed sustained NGFR and FOSL1 expression after 10d of DOX

939 treatment in cells with a significant knockdown of SOX4 (Fig. 8g, left panel) as well as a

940 significant decrease in proliferation of BMC1-M4 ( $p=9.8 e-09 ; p=5.7 e-03)$ and BMC4 $(p=1.3 e-$

941 05; $p=1.1 \mathrm{e}-04$ ) (Fig. 8g, right panel; Supplementary Fig. 15e). Therefore, we suggest that

942 SOX4 acts downstream of CD271 to control properties of MBM-derived cells and likely

943 maintains the proliferative and migratory state of MBM.

\section{Discussion}

946 The emergence of brain metastases is frequently observed in patients with melanoma, lung and breast cancer ${ }^{119}$ presenting a devastating step in the course of disease. Despite ongoing progress, the long-lasting therapeutic control of BM remains challenging and the majority of patients exhibit a poor prognosis due to progressive and multiple $\mathrm{BM}^{16}$. However, the emergence of multiple BM is poorly understood and might involve (i) the establishment of a founder clone that gives rise to multiple subclones or (ii) the transition of dormant micrometastases into actively proliferating macrometastases triggered by

953 microenvironmental cues and/or therapeutic interventions ${ }^{3,119,120}$. Whether primary tumors

954 can directly metastasize to the brain or tumor cells need a "priming" step while acquiring the capability of crossing the BBB during the sequential process of metastasis, remains elusive.

956

957 Here, we performed a molecular, genetic and epigenetic profiling of BM of stage IV melanoma (MBM) patients and uncovered that the expression of the epithelial marker Ecad and NGFR subdivided MBM into drug-naïve, potentially responsive and drug-resistant,

960 progressive tumors. Moreover, we established and characterized a panel of stable MBMderived cell lines that were molecularly distinct from conventional melanoma cell lines and enabled the analysis of programs establishing cellular dependencies. In addition, we provided evidence that therapeutic interventions inhibiting the acquired constitutive activation of BRAF likely foster the phenotype switch from Ecad ${ }^{+}$into NGFR/CD271 ${ }^{+}$cells. Considering that the expression of NGFR in melanoma cells accompanies a network of associated genes 
medRxiv preprint doi: https://doi.org/10.1101/2022.02.06.22270509; this version posted February 8, 2022. The copyright holder for this preprint (which was not certified by peer review) is the author/funder, who has granted medRxiv a license to display the preprint in perpetuity.

All rights reserved. No reuse allowed without permission.

966 such as mediators of a NCSC-phenotype $34,59,121$ - which was recently identified as a major

967 driver of $\mathrm{MRD}^{35}$ - we suggest that the upregulation of NGFR and associated factors such as

968 FOSL1 hallmarks the fate of relapse in the brain and intracranial progression. Although brain

969 metastasis per se is associated with poor prognosis of melanoma patients, high levels of

970 NGFR likely accelerate progression potentially via secreted extracellular vesicles ${ }^{37}$. Indeed,

971 CD271 ${ }^{\text {high }}$ MBM exhibited an invasive and stem-like phenotype predominantly observed in

972 extensively treated patients' tumors. Therefore, CD271/NGFR ${ }^{+}$microenvironmental cells

973 potentially facilitate tumor cell invasion and migration or aid in maintaining micrometastasis.

974 Although the molecular programs that control subclonal evolution and development of

975 multiple brain metastases remain elusive, the analysis of longitudinal metastases of one of

976 our patients (Pat 8) provided insights into the genetic landscapes. We observed that

977 mutations in BRAF or NRAS, RAC1, MYC, and CARD11 defined the genetic landscapes of

978 tumors. However, TargetSeq revealed that every tumor carried private mutations that were

979 mostly maintained in MBM-derived cell lines. The successful establishment of stable,

980 expandable tumor-derived cell lines served as an important tool for the investigation of

981 mechanisms of drug-response and provided insights into cellular dependencies and the

982 persistence of known driver mutations such as of BRAF, NRAS, RAC1 and genetic

983 subclones. Though, the cultivation of tumor-derived cell lines and subsequent passaging is

984 associated with global changes in methylome profiles ${ }^{122}$ and likely establishes cellular

985 dependencies that are distinct from in vivo processes. We observed that BMCs differentially

986 responded to dabrafenib, irrespective of presence of constitutive active RAC1 (RAC1 ${ }^{\mathrm{P} 29 S}$ ).

987 BMC2, carrying a BRAF ${ }^{\mathrm{N} 581 Y}$ mutation showed no response, as expected. BMC1-M1, BMC1-

988 M4 and BMC4 carried a comparable ground state of BRAF- and RAC1- but not MEK1- or

989 NRAS-mutations and responded differentially to dabrafenib. Interestingly, BMC1-M4

990 exhibited a higher sensitivity to dabrafenib than the correlated BMC1-M1 cells, which likely

991 reflected the therapeutic course. Whereas Pat8/M1 received radiation therapy and was

992 surgically removed prior to systemic dabrafenib/trametinib (BRAFi/MEKi) therapy, BMC1-M4

993 emerged under BRAFi/MEKi therapy. The excision of M4 tumor occurred after completion of 
medRxiv preprint doi: https://doi.org/10.1101/2022.02.06.22270509; this version posted February 8, 2022. The copyright holder for this preprint (which was not certified by peer review) is the author/funder, who has granted medRxiv a license to display the preprint in perpetuity.

All rights reserved. No reuse allowed without permission.

994 BRAFi/MEKi and subsequent ICi (nivolumab/ipilimumab) therapy. This therapeutic switch 995 was potentially causative for adoption of a dabrafenib sensitive phenotype of M4 that was 996 sustained in vitro. However, we cannot exclude that both tumors M1 and M4 independently 997 emerged from pre-existing dormant micrometastases that stem from a common extracranial tumor and therefore carried a common set of ground-state mutations. However, both tumors might have acquired additional mutations that have not been picked up by TargetSeq due to limitations of the amplicon panel. As resistance to BRAFi is frequently observed in melanoma 1001 patients $^{123,124}$, we sought for additional potential therapeutics. We discovered that MET 1002 receptor signaling was activated in MBM. Consistently, all BMCs responded towards the 1003 clinically approved non-ATP competitive inhibitor ARQ197 (tivantinib) ${ }^{125}$. Moreover, the actin 1004 filament interfering drug paclitaxel was effective in BMCs, suggesting that both therapeutics 1005 are potentially effective in BRAFi resistant MBM. Cell lines such as BMC1-M1 and BMC1-M4 1006 reflected the phenotypes of the initial tumors and maintained the patterns of genetic clones 1007 that were found in initial tumors. Moreover, we observed rather an enrichment than a 1008 depletion of genetic subclones.

1009 However, the Ecad ${ }^{+}$phenotype of MBM (M1)-derived cells was not maintained in vitro and 1010 during progression in vivo and was likely promoted by serum supplied TGF $\beta$ or inflammatory 1011 processes $^{126-128}$. Hence, specialized serum-free, chemically defined media may support the 1012 maintenance of $\mathrm{Ecad}^{+}$states in vitro. In addition, TGF $\beta$ signaling inhibits the activation of 1013 STAT5 signaling and antagonizes STAT5-mediated gene expression ${ }^{129,130}$ and might thus 1014 have reduced the effect of STAT5A expression and restoration of an Ecad ${ }^{+}$phenotype in 1015 BMCs. The loss of STAT5A signaling therefore might act in concert with increased TGF $\beta$ 1016 signaling to support the progression of MBM in vivo and phenotype switching in vitro. The 1017 latter possibly involves FOSL1 and STAT5A expression controlling the transition of 1018 Ecad ${ }^{\text {high }} / \mathrm{CD} 271^{\text {low }}$ into Ecad ${ }^{\text {low }} / \mathrm{CD} 271^{\text {high }}$ MBM, hence defining cellular subsets of MBM. 1019 Additional factors such as SOX4 control melanoma cell proliferation. Recently, Ecad was 1020 identified as a survival factor in invasive ductal carcinomas during different steps of 
medRxiv preprint doi: https://doi.org/10.1101/2022.02.06.22270509; this version posted February 8, 2022. The copyright holder for this preprint (which was not certified by peer review) is the author/funder, who has granted medRxiv a license to display the preprint in perpetuity.

All rights reserved. No reuse allowed without permission.

1021 metastasis $^{131}$ and might therefore control similar processes during extracranial and 1022 intracranial metastasis of melanoma.

1023

1024 Molecular programs that drive the emergence and progression of solitary and multiple brain 1025 metastases are poorly understood. Unraveling the mechanisms that control the migratory 1026 and invasive properties of tumor cells and drive intracranial spreading might leverage the 1027 development of new therapeutic strategies preventing intracranial progression. Here, we 1028 identified Ecad and NGFR/CD271 associated networks that potentially determine 1029 progression stages and drug response of MBM.

1030

1031

\section{Figure legends}

1032

1033

Fig. 1: MAPKi treatment increases invasiveness of melanoma. a.) Schematic 1034 representation of the metastatic cascade establishing extracranial (EM1, EM2, EMn, etc.) 1035 and intracranial metastases and routes of intracranial metastasis leading to sub clonal 1036

1037 progression by subclonal evolution. b.) Immunohistochemistry (IHC) of CD271 in a 1038 representative MBM of patients who received combinatory therapies: BRAFi/ MEKi 1039 (dabrafenib/ trametinib), ICi (nivolumab and/or ipilimumab) or radiation therapy. Scale bars 1040 indicate $50 \mu \mathrm{m}$. Right panel: NGFR expression levels of melanoma pre- and post RAFi/MEKi 1041 therapy (study GSE77940), one tumor has been excluded (red filled circle) in each group. T1042 test was used to calculate significance. c.) GSEA of pre- and post-treatment melanoma 1043 revealed enrichment of undifferentiated, neural crest (NC)-like, anti-PD-1 resistant/ NGFR ${ }^{\text {high }}$ 1044 and invasive cells in post-treatment melanoma. False-discovery rate (FDR) indicates 1045 significance of analysis. d.) IHC of matched initial and relapsed tumors revealed CD271 ${ }^{+}$ 1046 tumor cells that showing infiltration of the brain tumor environment (BTE) and formation and 1047 micrometastases. Hematoxylin and eosin (H\&E) staining shows discrimination of tumor 1048 (MBM) and BTE. Scale bars indicate $50 \mu \mathrm{m}$. 
medRxiv preprint doi: https://doi.org/10.1101/2022.02.06.22270509; this version posted February 8, 2022. The copyright holder for this preprint (which was not certified by peer review) is the author/funder, who has granted medRxiv a license to display the preprint in perpetuity.

All rights reserved. No reuse allowed without permission.

1049 Fig 2: Characterization of MBM revealed different molecular subtypes. a.) Schematic 1050 overview about melanoma patient-derived MBM samples regarding their concordance, 1051 intracranial site and BRAF/NRAS mutation status. b.) Supervised clustering of MBM $(n=16)$ 1052 and BC $(n=3)$ revealed clustering independent from intracranial sites of discordant MBM or 1053 genetic state. Classifiers indicate the presence of tumors featuring an undifferentiated-neural 1054 crest (NC)-like or pigmented, invasive, proliferative, NGFR ${ }^{\text {high }}$ state or expressed MITF1055 targets or genes involved in cell adhesion represented in the top1000 variably expressed 1056 genes. c.) Heat map representing the top 1000 variably methylated $\mathrm{CpG}$ islands among 1057 MBM, BRAF mutations status is indicated.

Fig 3: Intracranial progression accompanied an Ecad ${ }^{+}$to $C D 271^{+}$phenotype switch. a.)

1059

1060

1061

1062

1063

1064

1065

1066

1067

1068

1069

1070

1071

1072

1073

1074

Timeline indicating the therapeutic history and time points of surgical removal of tumors, cerebrospinal fluid (CSF) and establishment of tumor-derived cell lines of Pat8, initially diagnosed with primary melanoma in 2017. b.) Magnetic resonance imaging (MRI) of M1 and M4, reflecting disease progression (left panels). Hematoxylin/eosin (H\&E) and immunohistochemistry (IHC) for CD271 indicates rare CD271+ cells in M1 but a high level of CD271 expression in M4 (center and right panels). c.) May-Gruenwald (May-Gruenw.) staining and IHC for HMB45 indicates the presence of MBM cells in CSF (right panels). d.) IF of a M1 concordant lymph node metastasis (LN-MET) for Ecad and CD271/p75 ${ }^{\mathrm{NTR}}$, indicating unique and co-expression of both (left panels). Comparative imaging of M1 and M4 for levels of cell surface expression of Ecad/ DECMA-1 and total levels of CD271. KBA.62 served as marker of stem-like and non-stem like human melanoma cells (right panels). Scales in (b-d) indicate $50 \mu \mathrm{m}$. e.) Expression levels (Log2FPKM) of Ecad (CDH1), NGFR and additional markers of invasion and progression, illustrate the difference of phenotypes of M1 and M4. Levels are color coded. f.) Box plots indicate the levels (mean $\pm s d v)$ of genes indicating pigmented, invasive of CD271/NGFR-driven tumor cells in M1 and M4. T-test was used for calculation of $p$-values. 
medRxiv preprint doi: https://doi.org/10.1101/2022.02.06.22270509; this version posted February 8, 2022. The copyright holder for this preprint (which was not certified by peer review) is the author/funder, who has granted medRxiv a license to display the preprint in perpetuity.

All rights reserved. No reuse allowed without permission.

1075 Fig. 4 Expression of E-cadherin and NGFR defines molecular subgroups of MBM. a.) IF

1076 and confocal microscopy of epithelial-like MBM (Pat 11) and a matched pair of initial (Pat 19, 1077 frontal lobe, left) and relapsed (Pat 19-R, cerebellum, left) tumors for Ecad and KBA.62 1078 revealed intense staining and proper membrane localization of Ecad ( 80\% of cells) in Pat 107919 but a reduced level ( 50\%) and punctuated localization in Pat 19-R (left panels). IF of 1080 spinal and concordant cerebral metastases demonstrated the maintenance of Ecad 1081 expression in extra- and intracerebral metastases. Bars indicate $50 \mu \mathrm{m}$. b.) Association of 1082 Ecad/CDH1 and CD271/NGFR correlated genes displayed a mutually exclusive pattern. c.) 1083 Molecular subclustering of MBM regarding the expression of Ecad- and CD271-associated or 1084 immune modulatory genes. Additional molecular subgroups (BRAF ${ }^{\text {mut }}$ vs. wt; TIL ${ }^{\text {high }}$ vs. low) 1085 and levels of Ecad and CD271 expression are color coded. Heat map presents a supervised, 1086 euclidean and ward.D clustering. d.) GSEA of Ecad ${ }^{\text {high }}$ and CD271/NGFR ${ }^{\text {high }}$ subsets for 1087 representation of gene signatures specifying a proliferative, NGFR-driven or invasive 1088 phenotype of MBM. FDR indicates the significance of enrichment; ES, enrichment score; NES, normalized enrichment score. 10,000 permutations were performed.

Fig. 5: MBM-derived cell lines serve as in vitro models and exhibited distinct migratory

phenotypes. a.) Simplified experimental scheme of MBM-establishment, $1^{\circ}$ tumor cell cultures contained admixed cells such as astrocytes, which were subsequently lost. $2^{\circ}$ cells comprised a heterogeneous mixture of tumor cells that were accessible for genetic modification such as shRNA-based knockdown or generation of reporters. b.) IF of a representative set of BMCs for CD271 and phalloidin (Phallo.), bars indicate $50 \mu \mathrm{m}$. c.) Flow cytometric analysis of viable, adherently grown BMCs for cell surface expression of potential drivers of migration AXL, MET (FITC-labeled) and CD271 (APC-labeled, left panels) or cell surface levels of CD271 of suspension cells (right panels). 50,000 cells were monitored. d.) Embedding of BMCs in matrigel established three-dimensional growing spheroids and demonstrated differences of invasive phenotypes. Bars indicate $50 \mu \mathrm{m}$. e.) Experimental setup of in vivo experiments (upper panel). CD-1 nude mice $(n=3)$ were inoculated with patient 
medRxiv preprint doi: https://doi.org/10.1101/2022.02.06.22270509; this version posted February 8, 2022. The copyright holder for this preprint (which was not certified by peer review) is the author/funder, who has granted medRxiv a license to display the preprint in perpetuity.

All rights reserved. No reuse allowed without permission.

1103 ascertained over time for up to $21 \mathrm{~d}$ by $\mathrm{MRI}$ in T1 (lower left panel). Representative MRI

1104 images taken 7, 14 and 21 days (D) after transplantation depict tumor formation (dotted 1105 yellow line) in BMC1-M4 but not BMC1-M1 inoculated and contrasted animals (right panels).

1106 The experiments were terminated once a tumor volume of at least $20 \mathrm{~mm}^{3}$ was reached or at 1107 latest on day 49.

1108

1109

1110

1111

1112

1113

1114

1115

1116

1117

1118

1119

1120

1121

1122

1123

1124

1125

1126

1127

1128

1129

Fig. 6: TargetSeq of BMCs and concordant MBM provided insight into the persistence of genetic subclones and subclonal evolution. a.) Scatter plots showing the comparison of BMCs and concordant MBM ( 13,000 genes/sample) indicate a high concordance of transcriptomes of $B M C 1-M 1$ vs. $M 1(R=0.89, p<2.2 e-16)$ and $B M C 1-M 4$ vs. $M 4(R=0.90$, $p<2.2 e-16)$ and narrow differences of BMCs $(R=0.86, p<2.2 e-16)$. All $p$-values were calculated by a two-tailed paired t-test. Levels are color coded and depict levels of concordance. b.) Oncoprint map depicts genetic modifications of 42 genes as determined by high-depth (>775x mean coverage) TargetSeq. Shown are missense (SNVs) and nonsensemutations (STOP), percentage of microsatellite instability (MSI), level of tumor-mutation burden (TMB-score) and numbers of alterations per sample and per gene. c.) Assessment of sensitivity of BMCs towards increasing doses $(1 \mathrm{nM}-10 \mu \mathrm{M})$ of dabrafenib as determined by live-cell imaging based proliferation indicated by percentage of confluence. d.) Computation of IC50 values by fit-curves of responses of BMCs and conventional cell lines A2058, A375 and MeWo towards dabrafenib (BRAFi), paclitaxel (cytoskeleton targeting drug) and tivantinib (non-ATP competitive inhibitor of c-MET). e.) Depiction of IC50 values of investigated BMCs.

Fig. 7: The brain microenvironment maintains an Ecad $^{+}$tumor cell phenotype. a.) Schematic representation of tumor progression in vivo and phenotype-switch in vitro. In vivo: MBM are surrounded by normal and reactive astrocytes/microglia, neurons and immune cells. The interaction of tumor cells with microenvironmental cells determines tumor progression stages. Likely, inflammatory processes foster MBM progression. In vitro: the derivation and maintenance of tumor cells was associated with a loss of microenvironmental 
medRxiv preprint doi: https://doi.org/10.1101/2022.02.06.22270509; this version posted February 8, 2022. The copyright holder for this preprint (which was not certified by peer review) is the author/funder, who has granted medRxiv a license to display the preprint in perpetuity.

All rights reserved. No reuse allowed without permission.

1130 cells and transition of $\mathrm{Ecad}^{+}$into $\mathrm{CD}^{271^{+}}$cells via transient $\mathrm{Ecad}^{+} / \mathrm{CD} 271^{+}$cells. b.)

1131 Scatterplot representation of M1 and BMC1-M1 enriched genes. c.) IF of M1 for Ecad and 1132 KBA.62 (left panel) and analysis of cell surface levels of Ecad by flow cytometry and 1133 DECMA1 antibody; 50,000 cells were recorded (right panels). d.) Supervised heat map 1134 depicting levels of invasive and proliferative classifier genes in M1, M4 and associated 1135 BMCs. Ecad and CD271 status is color-coded (left panel). Venn-diagram displays a 1136 comparison of differentially regulated genes (DEGs) between M1 vs. BMC1-M1 and M4 vs. 1137 M1, 100 genes common to both groups were identified. NGFR, FOSL1 and FOSL2 were among the significantly, most up-regulated genes. STAT5A and CDH1 were expressed in M1 but downregulated in BMC1-M1. e.) Box plots represent a significant association of levels of 1140 STAT5A and expression of Ecad in extracranial metastases (EM, $p=2 e-04)$ but not BM or 1141 primary tumors (PT, $\mathrm{p}=0.028$ ) as determined by two-way anova using TCGA-SKCM 1142 (melanoma, MM) data. f.) IHC of M4 shows overlapping expression of Ecad and STAT5A and low STAT5A levels in brain parenchymal cells (left panels) and reduced levels of STAT5A at Ecad ${ }^{\text {high }}$-to-Ecad ${ }^{\text {low }}$ transition sites. Bars indicate $50 \mu \mathrm{m}$.

Fig. 8: CD271 and SOX4 control migratory and proliferative properties of BMCs. a.) IF of re-seeded suspension cells (SC) of BMC1-M4 cells for CD271 and phalloidin shows the maintenance of CD271 expression of SCs after re-attachment (upper panel). Bar diagrams indicates the percentage of suspension cells relative to adherent cells of BMC1-M1 and BMC1-M1 reporter cells (Ecad/NGFRrep) and BMC1-M4 in absence (-DOX) and presence (+DOX). The latter significantly decreased the number of SCs $(p=0.013)$. The seeding of 2,500 CD271 knockdown and control BMC1-M4 cells on a solidified layer of matrigel enabled

1152 the investigation of cell invasion (right scheme). b.) The knockdown of CD271 significantly 1153 reduced spheroid formation ( $\mathrm{p}=3.4 \mathrm{e}-12)$ and extracellular matrix invasion c.) Quantification of changes in spheroid growth as determined by colony diameters $(\mu \mathrm{m}), \mathrm{n}=122(-\mathrm{DOX})$ or n=120 (+DOX) spheroids were analyzed (upper panel). Two-dimensional proliferation was not significantly affected (lower panel). d.) Invasive cells that crossed the matrigel layer and 1157 attached to the bottom of wells were only observed in absence of DOX. Insets show GFP 
medRxiv preprint doi: https://doi.org/10.1101/2022.02.06.22270509; this version posted February 8, 2022. The copyright holder for this preprint (which was not certified by peer review) is the author/funder, who has granted medRxiv a license to display the preprint in perpetuity.

All rights reserved. No reuse allowed without permission.

expression upon DOX treatment, bars indicate $50 \mu \mathrm{m}$. e.) Live cell-imaging based scratch migration assay of BMC1-M1 cells revealed a significant decrease $(p=8.14 e-03)$ in the migratory capacity and a delayed wound closure (left panel). qPCR for potential drivers of migration in BMC1-M4 cells. The knockdown of CD271 was accompanied by reduced levels of SOX4, and MET but increased expression of AXL and HERC5 (center panel). Box plot shows a significant higher expression of SOX4 in MBM $(n=16)$ than brain controls $(B C, n=3)$, $p=0.044$ (right panel). f.) qPCR illustrates levels of SOX4 in indicated BMCs (upper panel), experimental scheme of DOX treatment of BMC1-M4 and BMC4 cells prior to live cellimaging based assessment of proliferation for $4 \mathrm{~d}$. g.) the efficient knockdown of SOX4 was validated by $\mathrm{qPCR}$ (left panel) and led to a strong significant $(p=9.8 e-09)$ decrease in proliferation (right panel). Significance was determined by a two-tailed paired t-test. Values depict mean \pm sdv, ${ }^{*} p<0.05,{ }^{* *} p<0.001$.

\section{Supplementary figure legends}

\section{Supplementary figure 1: Molecular subsets of post- and pre-MAPKi treatment} melanoma. a.) Whole tumor scans of extensively treated (coded) MBM (Pat 15, 17) indicating high levels of CD271 expression; scale bars indicate $5 \mathrm{~mm}$ or $50 \mu \mathrm{m}$. b.) Dot-plot representation indicates significant difference in levels of E-cadherin (CDH1) but not melanocyte-specific markers such as dopachrome-tautomerase (DCT) and MLANA (melanA; melanoma antigen recognized by $\mathrm{T}$ cells 1 ) in pre- versus pos-treatment melanoma (study GSE77940). c.) GSEA of pre- versus post-treatment melanoma for representation of gene signatures specifying CD271-associated genes (CD271-core UP) or MAPKi-induced EMT

Supplementary figure 2: Genetic characteristics of MBM. a.) Supervised clustering of MB and brain controls (Cortex, Pons, Cerebellum; Cereb.) demonstrating a clear difference and the presence of molecular signatures (Classifier) specifying the presence of exosomes, melanosomes, focal adhesion or extracellular matrix (ECM). b.) TargetSeq of MBM and brain 
medRxiv preprint doi: https://doi.org/10.1101/2022.02.06.22270509; this version posted February 8, 2022. The copyright holder for this preprint (which was not certified by peer review) is the author/funder, who has granted medRxiv a license to display the preprint in perpetuity.

All rights reserved. No reuse allowed without permission.

1185 controls (K1, K2) using a 50 gene panel (CHP2v) revealed mutations (single nucleotide

1186 variants, SNV) in 11 genes and provided insight into copy number changes (CNV gain, loss), 1187 insertion and deletions (INDEL) and nonsense mutations (STOP-gain). c.) Types of BRAF and NRAS mutations identified in (a), the mutation status was not determined (ND) in 10 $\operatorname{MBM}(21 \%)$.

Supplementary figure 3: Methylation of the ITGB7 promoter is associated with

improved survival. a.) Determination of tumor cell content via expression of PRAME (\%, related to BMC1-M1 cells, left panel). Scatter plot indicating the similarity of BRAF ${ }^{\text {mut }}$ and $\mathrm{BRAF}^{\mathrm{wt}} \mathrm{MBM}$ regarding the degree of methylation of $\sim 850 \mathrm{k} \mathrm{CpG}$ islands in promoter regions (right panel). Red dots indicate the most significant differentially methylated CpGs (FDRadjusted p-value $<0.05$ ). b.) Presentation of 46 differentially methylated CpG islands within promoters of 14 genes identified by global methylation analysis of $\mathrm{BRAF}^{\mathrm{mut}}$ and $\mathrm{BRAF}^{\mathrm{wt}}$ MBM. The grade of methylation is depicted by $\beta$-values (mean, $\beta \leq 0.5$, unmethylated; $\beta \geq 0.5$, methylated CpGs.) c.) Survival analysis of melanoma patients based on levels of expression of ITGB7 in brain metastases ( $n=80$, EGAS00001003672) showing that high ITGB7 levels are associated with favorable outcome.

Supplementary figure 4: The expression of NGFR discriminates M1 and M4. a.) MRI, H\&E and CD271 staining of M2, M3 reflecting differences in location and phenotypes of subclones and stages of progression. b.) Scatter plot of $\sim 13,000$ genes of M1 and M4 indicated the difference of both tumors $(R=0.85, p<2.2 e-16$, two-tailed paired t-test). c.) IF of a lymph node metastasis (LN-MET, M1 concordant) for single staining of Ecad (extracellular 1206 domain) and CD271/p75 ${ }^{\mathrm{NTR}}$. d-e.) IF for CD271, KBA.62 and Ecad/DECMA1 (N-terminal domain) of M1 indicates the rarity of $\mathrm{CD} 271^{+}$cells. In c-e, DAPI served as nuclear stain, confocal imaging was performed. Scale bars indicate $50 \mu \mathrm{m}$.

Supplementary figure 5: E-cadherin was expressed among different melanoma 1210 progression stages. a.) Box plot representation of levels of $\mathrm{Ecad} / \mathrm{CDH} 1$ in brain metastases $1211(B M, n=79)$ and non-concordant extracranial metastases (EM, $n=59$ ) of study 
medRxiv preprint doi: https://doi.org/10.1101/2022.02.06.22270509; this version posted February 8, 2022. The copyright holder for this preprint (which was not certified by peer review) is the author/funder, who has granted medRxiv a license to display the preprint in perpetuity.

All rights reserved. No reuse allowed without permission.

1212 EGAS00001003672. Statistical testing (*two-tailed paired t-test) revealed no significant 1213 difference $(p=0.61)$ of Ecad levels (left panel). Box plot representation of levels of $1214 \mathrm{Ecad} / \mathrm{CDH} 1$ in primary and metastatic melanoma of the SKCM ( $\mathrm{n}=472$, TCGA) set including rare $(n=6)$ BM. A one-way anova $(\wedge)$ indicated the significant difference $(p=0.0013)$ of Ecad levels among tumors (right panel). b.) Representation of levels of Ecad expression (log2 1217 FPKM) in MBM samples (blue bars) and brain controls (orange) and MBM-derived cell lines 1218 (BMC1-M1 and BMC1-M4). c.) Log2FPKM levels of NGFR expression in melanoma samples. d.) Box plots depict that levels of Ecad or NGFR significantly subdivide MBM into subgroups, (Ecad ${ }^{\text {high }}$ vs. low, $p=3.5 e-07 ; C D 271 / N G F R^{\text {high }}$ vs. low, $\left.p=1.1 . e-06\right)$, right panels.

e.) Enrichment of MITF-target signature genes in Ecad ${ }^{\text {high }}$ MBM of study EGAS00001003672 ( $n=80$, left panel) and MBM of this study ( $n=16$, center panel). No enrichment of MITF-target genes was observed in the CD271/NGFR ${ }^{\text {high }}$ subgroup of MBM (rigt panel). The analysis was performed with 10,000 permutations.

\section{Supplementary figure 6: Characterization of $\mathrm{CD}_{271^{\text {high }}}$ and $\mathrm{TIL}^{\text {high }}$ subsets of MBM. a.)}

Box plots depict a significant association of expression levels of NGFR with BRAF ${ }^{\mathrm{wt}}$ $(p=0.014)$ and expression of $\mathrm{CDH} 1$ with $\mathrm{BRAF}^{\mathrm{mut}}(\mathrm{p}=0.013)$ MBM. Single-sample GSEA (ssGSEA) depicts that nine signatures among them signatures associated with $\mathrm{p} 75^{\mathrm{NTR}} / \mathrm{NGFR}$ signaling and brain metastasis in breast cancer significantly $(p<0.05$, adjusted by BenjaminiHochberg) subdivides MBM into CD271/NGFR ${ }^{\text {high }}$ and low subsets (color coded). c.) GSEA of $\mathrm{CD} 271^{\text {high }}$ vs. low MBM shows a significant enrichment of signature genes that are predictive for breast cancer brain metastasis $(\mathrm{NES}=1.727$, FDR-adjusted $p$-value $=0.003$, left panel). IHC for CD3, a pan-marker of $\mathrm{T}$ lymphocytes subdivides MBM into $\mathrm{TIL}^{\text {high }}$ and low 1234 (center panel) and shows immune cell infiltration in M4 (right panel). Bars indicate $50 \mu \mathrm{m} . \mathrm{d}$.) Box plots indicate that expressions levels (log2 FPKM) of CD3D $(p=2.8 e-07)$ and CD8A $(p=2.6 e-04)$ significantly subdivided MBM into $\mathrm{TIL}^{\text {high }}$ and low subsets (left panels) and are of prognostic relevance as depicted by Kaplan-Meier survival curves. Analyses were performed with expression and survival data of study EGAS00001003672, higher levels of CD3G $(p=0.06)$ and CD8A ( $p=0.0029)$ were associated with increased survival (right panels). e.) 
medRxiv preprint doi: https://doi.org/10.1101/2022.02.06.22270509; this version posted February 8, 2022. The copyright holder for this preprint (which was not certified by peer review) is the author/funder, who has granted medRxiv a license to display the preprint in perpetuity.

All rights reserved. No reuse allowed without permission.

1240 GSEA of $\mathrm{TIL}^{\text {high }}$ and low subsets revealed increased inflammatory response (NES=2.449, 1241 FDR-adjusted pval<0.001) and astrocyte activation (astrogliosis, NES=1.842, FDR-adjusted 1242 pval<0.001) in TIL high tumors. GSEA was performed with 10,000 permutations. In (a) and (d) 1243 a two-tailed paired t-test was performed.

1244 Supplementary figure 7. AXL and CD271 expression in BMCs. a-b.) Flow cytometry of adherently grown BMC2, BMC3 and BMC53 for levels of CD271 or suspension cells (BMC2). c.) Box plots indicate that levels of $A X L$ expression (log2FPKM) between $B C$ and $M B M$ are not significantly different ( $p=0.061$, two-tailed paired t-test). d.) IF and confocal imaging depicted intracellular and membrane localization of AXL in BMC1-M1 and BMC1-M4 cells (left and center panels) and revealed AXL expression of in a MBM (Pat 4), right panel. e.) Co-expression and localization of CD271 (green) and p-AXL (red) in Pat 15. AXL phoshorylation was rarely observed in MBM (Pat 15, right panels). Bars indicate $50 \mu \mathrm{m}$.

Supplementary figure 8: MBM-derived cell lines (BMCs) show distinct migratory capacities and transcriptomic profiles. a.) Content of proliferative, $\mathrm{Ki} 67^{+}$cells in a drugnaïve (M1) and therapy-resistant (M4) MBM and associated in vitro cell culture models (left panels) and capacity of BrdU incorporation (right panel) indicate the maintenance of a proliferative phenotype of M4-derived (BMC1-M4) cells in vitro. $\mathrm{Ki}^{+} 7^{+}$and $\mathrm{BrdU}^{+}$cells (\% mean $\pm s d v$ ) were determined by counting of stained cells of three independent experiments. b.) Live-cell imaging based scratch-wound assay depicting an increased migratory phenotype of BMC2, BMC1-M4 and BMC4 but not BMC1-M1 and BMC3 cells. Values depict changes in wound width ( $\mu \mathrm{m}$ mean $\pm s d v)$ of three independent experiments. c.) Bar diagram displays values of wound width as determined by live cell-imaging at $0,24,48$ and $72 \mathrm{~h}$ after wounding. The migratory capacity of BMCs led to a significant decrease in wound widths 1263 after $24 \mathrm{~h}$ (left panel). Values depict mean \pm sdv of three independent experiments. 1264 Significance was determined by a two-tailed paired t-test, values depict mean $\pm \mathrm{sdv},{ }^{* *} \mathrm{p}<$ 1265 $0.001 ;{ }^{* *} \mathrm{p}<0.0001 \mathrm{~d}$.) Experimental set-up and timeline of MRI imaging of BMC1-M1 transplanted CD-1 nude mice $(n=3)$. MRI images (T1) of contrasted animals were taken after 
medRxiv preprint doi: https://doi.org/10.1101/2022.02.06.22270509; this version posted February 8, 2022. The copyright holder for this preprint (which was not certified by peer review) is the author/funder, who has granted medRxiv a license to display the preprint in perpetuity.

All rights reserved. No reuse allowed without permission.

1267 every week for a total of 49days (D). Tumor growth was detectable after 35days (yellow,

1268 dotted line). e.) Tumor growth over time as depicted by tumor volume $\left(\mathrm{mm}^{3}\right)$ of BMC1-M1 1269 inoculated animals.

Supplementary figure 9: BMCs and conventional melanoma cell lines feature common

and distinct properties. a.) Western blot of whole protein lysates of BMCs for levels of CD271/p75 ${ }^{\mathrm{NTR}}$, quantification was related to GAPDH. b.) IF for CD271, GFAP (left panels) or CD271 and KBA.62 (right panel) and confocal imaging of brain tumors established by intracranial injection of $1 \times 10^{3}$ A375 cells $\sim 25$ days after transplantation. Three-dimensional representation was performed from z-stacks using the Arivis tool. c.) Correlation heat map of MBM, BCs, BMCs, a patient-derived cell line establish from a lymph node metastasis

1277 (T2002) and conventional cell lines MeWo, A375 and human melanocytes depicts a discrete clustering of conventional cell lines and BMCs. d.) The RAC1 ${ }^{\mathrm{P} 29 \mathrm{~S}}$ mutation forces formation of membrane ruffles in BMC1-M1 cells ${ }^{132}$ and showed co-enrichment of actin filaments and CD271 as depicted by z-stacking based three-dimensional modeling of BMC1-M1 cells stained for CD271 and phalloidin (left panels). The formation of membrane ruffles was established in WM35 and A375 cells following lentiviral infection with GFP or plasmids expressing constitutive active RAC1 ${ }^{\mathrm{P} 29 \mathrm{~S}}$ (right panels).

Supplementary figure 10: TargetSeq provided insight into subclonal heterogeneity. a.) Representation of allele frequencies (color-coded) of mutations identified by TargetSeq of MBM and BMCs. b.) PolyPhen2 prediction of a $\mathrm{NOTCH}^{\mathrm{S1128P}}$ mutation that raised in BMC1M4 cells. c.) Changes of allele frequencies of indicated mutations among longitudinal metastases, CSF and cell lines of Pat8 demonstrating the permissive character of BRAF, RAC1 and MYC in vivo and of CARD11, NOTCH3 and MAG in vitro. d.) Chromatogram of BMC4 cells depicting the detection of a BRAF ${ }^{\mathrm{V} 600 \mathrm{~K}}$ mutation by pyrosequencing.

Supplementary figure 11: BMCs feature different types of BRAF mutations that determine the response to dabrafenib. a.) Representation of confluence values relative to untreated controls and sensitivity of BMCs (BMC1-M1, BMC1-M4, BMC4) carrying druggable 
medRxiv preprint doi: https://doi.org/10.1101/2022.02.06.22270509; this version posted February 8, 2022. The copyright holder for this preprint (which was not certified by peer review) is the author/funder, who has granted medRxiv a license to display the preprint in perpetuity.

All rights reserved. No reuse allowed without permission.

1294 (BRAF $\left.^{\mathrm{V} 600 \mathrm{E} / \mathrm{K}}\right)$ and b.) non-druggable $\left(\mathrm{BRAF}^{\mathrm{N} 581 \mathrm{Y}}\right.$ ) mutations (BMC2) towards dabrafenib, first 1295 panel. Error bars are not shown in this representation. Dabrafenib concentration is indicated, 1296 DMSO served as treatment control. Second panel: Fit-curve based computation of IC50 values, comparison of dabrafenib sensitive BMC1-M4 and less sensitive BMCs.

Supplementary figure 12: The c-MET tyrosine kinase receptor control cell survival in

MBM. a.) Volcano plot depicting genes that are expressed in Ecad ${ }^{\text {low }}$ or Ecad ${ }^{\text {high }}$ MBM, cMET (MET) was identified as Ecad-associated gene. Only significantly regulated genes $1301(p<0.05)$ are shown (left panel). Box plots indicate expression levels of MET in non-classified $\mathrm{BM}$ and $\mathrm{EM}$ as well as in Ecad ${ }^{\text {high }}$ and Ecad ${ }^{\text {low }}$ tumors. MET was significantly higher expressed in BM ( $p=2.7 e-05$, center panel) and associated with Ecad ${ }^{\text {high }}$ tumors $(p=1.4 e-04$, two-way anova), right panel. b-c.) IHC of a representative set of MBM for total (MET) and activated/ phosphorylated (Tyr1234/1235, p-MET) levels of MET showing concordance in three out of four MBM (upper panels). Fluorescence-in situ hybridization (FISH) using a MET-specific and centromere-specific (CEP7) probe (lower panels). Quantification of MET copies revealed no amplification when MET copies were related to CEP7 (c.), upper panel). IF of BMC1-M1 cells revealed expression and a membrane ruffle-associated enrichment of MET receptor (lower panels). d.) Dose-response of indicated BMCs towards tivantinib (ARQ197) a non-ATP competitive MET inhibitor was effective in dabrafenib-resistant BMC2 cells. Drug-response is depicted as decrease in confluence over time, tivantinib was titrated, $(1 \mathrm{nM}-10 \mu \mathrm{M})$. Error bars indicate mean $\pm s d v$, eight technical replicates were analyzed, one out of three independent experiments is shown.

Supplementary figure 13. A transcription reporter live-cell imaging approach identified

Ecad-to-NGFR transition states. a.) Box plots represent a significant association of expression of CD271/NGFR and levels of FOSL1 in EM ( $p=8.2 e-07)$ and PT $(p=0.028)$ but not BM (left panel). Box plot representation of STAT5B expression in BM, EM and PT of TCGA-SKCM. Two-way anova $\left({ }^{\wedge}\right)$ revealed no significant association of STAT5B levels and expression of Ecad. b.) Scheme depicting a proposed interconnected relationship of Ecad ${ }^{+}$, 
medRxiv preprint doi: https://doi.org/10.1101/2022.02.06.22270509; this version posted February 8, 2022. The copyright holder for this preprint (which was not certified by peer review) is the author/funder, who has granted medRxiv a license to display the preprint in perpetuity.

All rights reserved. No reuse allowed without permission.

$1321 \mathrm{CD}^{271^{+}}$and intermediate state BMCs (upper part). Linear plasmid maps of reporters

1322 enabling the indirect tracking of NGFR expression via a NGFR-specific $3^{\prime}$-UTR-sequence

1323 based regulation of GFP mRNA stability and expression or tracking of Ecad expression via

1324 Ecad-promoter controlled expression of RFP or general tracking of cells via constitutively expressed iRFP (lower schemes). c.) IF of reporter cells prior to sorting, depicting unique and co-expression of reporters (upper panels). Bars indicate $50 \mu \mathrm{m}$. Lower panel: Fluorescenceactivated cell sorting (FACS) based isolation of iRFP $^{+} / \mathrm{RFP}^{+} \mathrm{BMC1}$-M1 cells. $^{\mathrm{d}}$.)

Quantification of Ecad ${ }^{+}$cells $3 d$ post FACS revealed a significant (two-tailed paired t-test) decreased level of Ecad ${ }^{+}$cells values depict mean $\pm s d v,{ }^{* *} p<0.001$. e.) Snapshots of NGFR ${ }^{+}$ into Ecad ${ }^{+}$transitioning BMC1-M1 reporter cells (Movie 1) at days 0, 4. In (c) and (e) bars indicate $50 \mu \mathrm{m}$ and $200 \mu \mathrm{m}$.

Supplementary figure 14: STAT5A expression and activation is not sufficient for restoration of Ecad ${ }^{+}$phenotypes of BMCs. a.) IF of BMC4 cells retrovirally infected with an empty-control plasmid or plasmids expressing wildtype $\left(S T A T 5 A^{\text {wt }}\right)$ or constitutive active $\left(\right.$ STAT5A $\left.^{\text {S710F}}\right)$ for levels and localization of STAT5A. Transgene expression was monitored via IRES-GFP. Bars indicate $50 \mu \mathrm{m}$ (left panels). Flow cytometry for DECMA $1^{+}$cells revealed a weak increase of Ecad/DECMA $1^{+}$cells in $\mathrm{GFP}^{+}$(exhibited transgene expression) and GFP (did not exhibit transgene expression). Values depict mean \pm sdv of two biological replicates.

Supplementary figure 15: SOX4 controls survival-mediating programs downstream of

CD271 in BMCs. a.) Western blot shows the efficient knockdown of CD271 in conventional (A375, WM35) and MBM-derived cell lines in presence of DOX (4 $\mu \mathrm{g} / \mathrm{ml})$ administered for 714d. Tubulin served as loading control (left panel). Volcano plot shows significantly DEGs 1343 (FDR-adjusted $\mathrm{p}<0.05)$ in BMC1-M1 cells with a validated knockdown of CD271. SOX4 1344 (padj=1.61e-13), SNAI2 (padj=1.36e-21) and HERC5 (padj=3.33E-69) were among the most 1345 significantly regulated genes, besides NGFR (padj=3.36e-09) (right panel). b.) Comparative analysis of candidate mediators of survival in T2002 and BMC1-M1 cells. Most commonly downregulated genes are shown, values depict log2 fold change (FC) related to -DOX cells 
medRxiv preprint doi: https://doi.org/10.1101/2022.02.06.22270509; this version posted February 8, 2022. The copyright holder for this preprint (which was not certified by peer review) is the author/funder, who has granted medRxiv a license to display the preprint in perpetuity.

All rights reserved. No reuse allowed without permission.

1348 (left panel). c.) Box plots depict a significant reduction $(p<2.2 e-16)$ in colony diameters of 1349 BMC1-M4 spheroids following knockdown of NGFR in a second independent experiment. d.)

1350 The knockdown of CD271 decreased the migratory capacity of BMC2 cells as indicated by changes in wound width $(\mu \mathrm{m})$, left panel and relative (Rel.) wound density (\%), right panel.

e.) knockdown of SOX4 in BMC4 cells significantly reduced the proliferative capacity of cells, two independent experiments of eight technical replicates are shown (left and center panels).

1354 The knockdown of SOX4 was independently validated in BMC1-M4 cells (right panel). 1355 Significance was determined by a two-tailed paired t-test. Values depict mean \pm sdv, ${ }^{*} p<$ $0.05,{ }^{* *} p<0.001$

\section{References}

13591 Singh, R. et al. Epidemiology of synchronous brain metastases. Neurooncol Adv 2, vdaa041, doi:10.1093/noajnl/vdaa041 (2020).

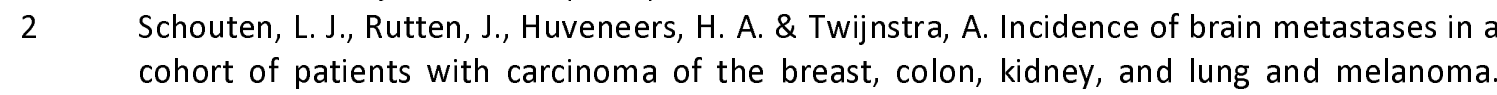
Cancer 94, 2698-2705, doi:10.1002/cncr.10541 (2002).

3 Redmer, T. Deciphering mechanisms of brain metastasis in melanoma - the gist of the matter. Mol Cancer 17, 106, doi:10.1186/s12943-018-0854-5 (2018).

4 Lau, P. K. H. et al. Melanoma brain metastases that progress on BRAF-MEK inhibitors demonstrate resistance to ipilimumab-nivolumab that is associated with the Innate PD-1 Resistance Signature (IPRES). J Immunother Cancer 9, doi:10.1136/jitc-2021-002995 (2021).

5 Long, G. V. et al. Combination nivolumab and ipilimumab or nivolumab alone in melanoma brain metastases: a multicentre randomised phase 2 study. Lancet Oncol 19, 672-681, doi:10.1016/S1470-2045(18)30139-6 (2018).

6 Davies, M. A. et al. Prognostic factors for survival in melanoma patients with brain metastases. Cancer 117, 1687-1696, doi:10.1002/cncr.25634 (2011). Sandru, A., Voinea, S., Panaitescu, E. \& Blidaru, A. Survival rates of patients with metastatic malignant melanoma. J Med Life 7, 572-576 (2014). Hoon, D. S. et al. Molecular detection of metastatic melanoma cells in cerebrospinal fluid in melanoma patients. J Invest Dermatol 117, 375-378, doi:10.1046/j.0022-202x.2001.01417.x (2001).

9 Hurst, R. E., Bastian, A., Bailey-Downs, L. \& Ihnat, M. A. Targeting dormant micrometastases: rationale, evidence to date and clinical implications. Ther Adv Med Oncol 8, 126-137, doi:10.1177/1758834015624277 (2016).

10 Izraely, S. et al. The metastatic microenvironment: brain-residing melanoma metastasis and dormant micrometastasis. Int J Cancer 131, 1071-1082, doi:10.1002/ijc.27324 (2012).

11 Schwartz, H. et al. Incipient Melanoma Brain Metastases Instigate Astrogliosis and Neuroinflammation. Cancer Res 76, 4359-4371, doi:10.1158/0008-5472.CAN-16-0485 (2016).

12 Chason, J. L., Walker, F. B. \& Landers, J. W. Metastatic carcinoma in the central nervous system and dorsal root ganglia. A prospective autopsy study. Cancer 16, 781-787, doi:10.1002/1097-0142(196306)16:6<781::aid-cncr2820160614>3.0.co;2-m (1963). 
medRxiv preprint doi: https://doi.org/10.1101/2022.02.06.22270509; this version posted February 8, 2022. The copyright holder for this preprint (which was not certified by peer review) is the author/funder, who has granted medRxiv a license to display the preprint in perpetuity.

All rights reserved. No reuse allowed without permission.

13 Madajewicz, S., Karakousis, C., West, C. R., Caracandas, J. \& Avellanosa, A. M. Malignant melanoma brain metastases. Review of Roswell Park Memorial Institute experience. Cancer 53, 2550-2552, doi:10.1002/1097-0142(19840601)53:11<2550::aidcncr2820531129>3.0.co;2-b (1984).

14 Fidler, I. J., Schackert, G., Zhang, R. D., Radinsky, R. \& Fujimaki, T. The biology of melanoma brain metastasis. Cancer Metastasis Rev 18, 387-400, doi:10.1023/a:1006329410433 (1999).

15 Bander, E. D. et al. Melanoma brain metastasis presentation, treatment, and outcomes in the age of targeted and immunotherapies. Cancer 127, 2062-2073, doi:10.1002/cncr.33459 (2021).

16 Davies, M. A. et al. Dabrafenib plus trametinib in patients with BRAF(V600)-mutant melanoma brain metastases (COMBI-MB): a multicentre, multicohort, open-label, phase 2 trial. Lancet Oncol 18, 863-873, doi:10.1016/S1470-2045(17)30429-1 (2017).

17 Planchard, D. et al. Dabrafenib plus trametinib in patients with previously untreated BRAF(V600E)-mutant metastatic non-small-cell lung cancer: an open-label, phase 2 trial. Lancet Oncol 18, 1307-1316, doi:10.1016/S1470-2045(17)30679-4 (2017).

18 Parakh, S. et al. Efficacy of anti-PD-1 therapy in patients with melanoma brain metastases. $\mathrm{Br}$ J Cancer 116, 1558-1563, doi:10.1038/bjc.2017.142 (2017).

19 Wang, J. et al. A Secondary Mutation in BRAF Confers Resistance to RAF Inhibition in a BRAF(V600E)-Mutant Brain Tumor. Cancer Discov 8, 1130-1141, doi:10.1158/2159-8290.CD$17-1263$ (2018).

20 Manzano, J. L. et al. Resistant mechanisms to BRAF inhibitors in melanoma. Ann Transl Med 4, 237, doi:10.21037/atm.2016.06.07 (2016).

21 Kelley, K., Knisely, J., Symons, M. \& Ruggieri, R. Radioresistance of Brain Tumors. Cancers (Basel) 8, doi:10.3390/cancers8040042 (2016).

22 Hugo, W. et al. Genomic and Transcriptomic Features of Response to Anti-PD-1 Therapy in Metastatic Melanoma. Cell 168, 542, doi:10.1016/j.cell.2017.01.010 (2017).

23 Landsberg, J. et al. Melanomas resist T-cell therapy through inflammation-induced reversible dedifferentiation. Nature 490, 412-416, doi:10.1038/nature11538 (2012).

24 Obenauf, A. C. et al. Therapy-induced tumour secretomes promote resistance and tumour progression. Nature 520, 368-372, doi:10.1038/nature14336 (2015).

25 Siracusa, R., Fusco, R. \& Cuzzocrea, S. Astrocytes: Role and Functions in Brain Pathologies. Front Pharmacol 10, 1114, doi:10.3389/fphar.2019.01114 (2019).

26 Bachiller, S. et al. Microglia in Neurological Diseases: A Road Map to Brain-Disease Dependent-Inflammatory Response. Front Cell Neurosci 12, 488, doi:10.3389/fncel.2018.00488 (2018).

27 Sofroniew, M. V. Astrogliosis. Cold Spring Harb Perspect Biol 7, a020420, doi:10.1101/cshperspect.a020420 (2014).

28 Radke, J., Rossner, F. \& Redmer, T. CD271 determines migratory properties of melanoma cells. Sci Rep 7, 9834, doi:10.1038/s41598-017-10129-z (2017).

29 Thankamony, A. P., Saxena, K., Murali, R., Jolly, M. K. \& Nair, R. Cancer Stem Cell Plasticity - A Deadly Deal. Front Mol Biosci 7, 79, doi:10.3389/fmolb.2020.00079 (2020).

30 Phi, L. T. H. et al. Cancer Stem Cells (CSCs) in Drug Resistance and their Therapeutic Implications in Cancer Treatment. Stem Cells International 2018, 5416923, doi:10.1155/2018/5416923 (2018).

31 Li, Y., Wang, Z., Ajani, J. A. \& Song, S. Drug resistance and Cancer stem cells. Cell Communication and Signaling 19, 19, doi:10.1186/s12964-020-00627-5 (2021).

32 Redmer, T. et al. The role of the cancer stem cell marker CD271 in DNA damage response and drug resistance of melanoma cells. Oncogenesis 6, e291, doi:10.1038/oncsis.2016.88 (2017).

33 Redmer, T. et al. The nerve growth factor receptor CD271 is crucial to maintain tumorigenicity and stem-like properties of melanoma cells. PLoS One 9, e92596, doi:10.1371/journal.pone.0092596 (2014). 
medRxiv preprint doi: https://doi.org/10.1101/2022.02.06.22270509; this version posted February 8, 2022. The copyright holder for this preprint (which was not certified by peer review) is the author/funder, who has granted medRxiv a license to display the preprint in perpetuity.

All rights reserved. No reuse allowed without permission.

\begin{tabular}{|c|c|c|}
\hline 140 & 34 & $\begin{array}{l}\text { dal, A. \& Redmer, T. Decoding the Role of CD271 in Melanoma. Cancers (Basel) } \\
\text { i:10.3390/cancers12092460 (2020). }\end{array}$ \\
\hline 142 & 35 & $\begin{array}{l}\text { Imbow, F. et al. Toward Minimal Residual Disease-Directed Therapy in Melanoma. Cell 174, } \\
\text { 3-855 e819, doi:10.1016/i.cell.2018.06.025 (2018). }\end{array}$ \\
\hline $\begin{array}{l}1444 \\
1445 \\
1446\end{array}$ & 36 & $\begin{array}{l}\text { Marin-Bejar, O. et al. A neural crest stem cell-like state drives nongenetic resistance to } \\
\text { targeted therapy in melanoma. bioRxiv, } 2020.2012 .2015 .422929 \text {, } \\
\text { doi:10.1101/2020.12.15.422929 (2020). }\end{array}$ \\
\hline $\begin{array}{l}447 \\
448 \\
449\end{array}$ & 37 & $\begin{array}{l}\text { García-Silva, S. et al. Melanoma-derived small extracellular vesicles induce } \\
\text { lymphangiogenesis and metastasis through an NGFR-dependent mechanism. Nature Cancer, } \\
\text { doi:10.1038/s43018-021-00272-y (2021). }\end{array}$ \\
\hline $\begin{array}{l}4450 \\
1451 \\
1452\end{array}$ & 38 & $\begin{array}{l}\text { Yaar, M., Grossman, K., Eller, M. \& Gilchrest, B. A. Evidence for nerve growth factor-mediated } \\
\text { paracrine effects in human epidermis. J Cell Biol 115, 821-828, doi:10.1083/jcb.115.3.821 } \\
\text { (1991). }\end{array}$ \\
\hline 1453 & 39 & $\begin{array}{l}\text { ang, A. et al. E-cadherin is the major mediator of human melanocyte adhesion to } \\
\text { eratinocytes in vitro. J Cell Sci } 107 \text { ( Pt 4), } 983-992 \text { (1994). }\end{array}$ \\
\hline 1455 & 40 & $\begin{array}{l}\text { 'Arcy, C. \& Kiel, C. Cell Adhesion Molecules in Normal Skin and Melanoma. Biomolecules 11, } \\
\text { oi:10.3390/biom11081213 (2021). }\end{array}$ \\
\hline $\begin{array}{l}1457 \\
1458 \\
1459\end{array}$ & 41 & $\begin{array}{l}\text { Redmer, T. et al. E-cadherin is crucial for embryonic stem cell pluripotency and can replace } \\
\text { OCT4 during somatic cell reprogramming. EMBO Rep 12, 720-726, } \\
\text { doi:10.1038/embor.2011.88 (2011). }\end{array}$ \\
\hline $\begin{array}{l}1460 \\
1461 \\
1462\end{array}$ & 42 & $\begin{array}{l}\text { Larue, L. \& Bellacosa, A. Epithelial-mesenchymal transition in development and cancer: role } \\
\text { of phosphatidylinositol } 3^{\prime} \text { kinase/AKT pathways. Oncogene 24, 7443-7454, } \\
\text { doi:10.1038/sj.onc.1209091 (2005). }\end{array}$ \\
\hline $\begin{array}{l}1463 \\
1464 \\
1465\end{array}$ & 43 & $\begin{array}{l}\text { Jiang, H., Lei, R., Ding, S. W. \& Zhu, S. Skewer: a fast and accurate adapter trimmer for next- } \\
\text { generation sequencing paired-end reads. BMC Bioinformatics 15, 182, doi:10.1186/1471- } \\
\text { 2105-15-182 (2014). }\end{array}$ \\
\hline $\begin{array}{l}1466 \\
1467\end{array}$ & 4 & $\begin{array}{l}\text { nen, S., Zhou, Y., Chen, Y. \& Gu, J. fastp: an ultra-fast all-in-one FASTQ preprocessor. } \\
\text { oinformatics 34, i884-i890, doi:10.1093/bioinformatics/bty560 (2018). }\end{array}$ \\
\hline $\begin{array}{l}1468 \\
1469\end{array}$ & 45 & $\begin{array}{l}\text { Hat2: accurate alignment of transcriptomes in the presence of insertions, } \\
\text { e fusions. Genome Biol 14, R36, doi:10.1186/gb-2013-14-4-r36 (2013). }\end{array}$ \\
\hline $\begin{array}{l}1470 \\
1471 \\
1472\end{array}$ & 46 & $\begin{array}{l}\text { Liao, Y., Smyth, G. K. \& Shi, W. The R package Rsubread is easier, faster, cheaper and better } \\
\text { for alignment and quantification of RNA sequencing reads. Nucleic Acids Res 47, e47, } \\
\text { doi:10.1093/nar/gkz114 (2019). }\end{array}$ \\
\hline 1473 & 47 & $\begin{array}{l}\text { Love, M. I., Huber, W. \& Anders, S. Moderated estimation of fold change and dispersion for } \\
\text { RNA-seq data with DESeq2. Genome Biol 15, 550, doi:10.1186/s13059-014-0550-8 (2014). }\end{array}$ \\
\hline $\begin{array}{l}1475 \\
1476\end{array}$ & 48 & $\begin{array}{l}\text { Wu, T. et al. clusterProfiler 4.0: A universal enrichment tool for interpreting omics data. } \\
\text { Innovation }(N Y) \text { 2, 100141, doi:10.1016/j.xinn.2021.100141 (2021). }\end{array}$ \\
\hline $\begin{array}{l}1477 \\
1478 \\
1479\end{array}$ & 49 & $\begin{array}{l}\text { Gu, Z., Eils, R. \& Schlesner, M. Complex heatmaps reveal patterns and correlations in } \\
\text { multidimensional genomic data. Bioinformatics 32, } \\
\text { doi:10.1093/bioinformatics/btw313 (2016). }\end{array}$ \\
\hline 1480 & 50 & $\begin{array}{l}\text { Genomes Project, C. et al. A global reference for human genetic variation. Nature 526, 68-74, } \\
\text { doi:10.1038/nature15393 (2015). }\end{array}$ \\
\hline $\begin{array}{l}1482 \\
1483\end{array}$ & 51 & $\begin{array}{l}\text { Muller, F. et al. RnBeads 2.0: comprehensive analysis of DNA methylation data. Genome Biol } \\
\text { 20, 55, doi:10.1186/s13059-019-1664-9 (2019). }\end{array}$ \\
\hline $\begin{array}{l}1484 \\
1485\end{array}$ & 52 & $\begin{array}{l}\text { Pidsley, R. et al. A data-driven approach to preprocessing Illumina } 450 \mathrm{~K} \text { methylation array } \\
\text { data. BMC Genomics 14, 293, doi:10.1186/1471-2164-14-293 (2013). }\end{array}$ \\
\hline $\begin{array}{l}1486 \\
1487 \\
1488\end{array}$ & 53 & $\begin{array}{l}\text { lootha, V. K. et al. PGC-1alpha-responsive genes involved in oxidative phosphorylation are } \\
\text { oordinately downregulated in human diabetes. Nat Genet } 34,267-273 \text {, doi:10.1038/ng1180 } \\
\text { 2003). }\end{array}$ \\
\hline $\begin{array}{l}1489 \\
1490 \\
1491\end{array}$ & 54 & $\begin{array}{l}\text { Subramanian, A. et al. Gene set enrichment analysis: a knowledge-based approach for } \\
\text { interpreting genome-wide expression profiles. Proc Natl Acad Sci U S A 102, 15545-15550, } \\
\text { doi:10.1073/pnas.0506580102 (2005). }\end{array}$ \\
\hline
\end{tabular}


$55 \mathrm{Xu}$, L. et al. Gene expression changes in an animal melanoma model correlate with aggressiveness of human melanoma metastases. Mol Cancer Res 6, 760-769, doi:10.1158/1541-7786.MCR-07-0344 (2008).

56 Hoek, K. S. et al. In vivo switching of human melanoma cells between proliferative and invasive states. Cancer Res 68, 650-656, doi:10.1158/0008-5472.CAN-07-2491 (2008).

57 Hugo, W. et al. Genomic and Transcriptomic Features of Response to Anti-PD-1 Therapy in Metastatic Melanoma. Cell 165, 35-44, doi:10.1016/j.cell.2016.02.065 (2016).

58 Cancer Genome Atlas, N. Genomic Classification of Cutaneous Melanoma. Cell 161, 16811696, doi:10.1016/j.cell.2015.05.044 (2015).

59 Boshuizen, J. et al. Reversal of pre-existing NGFR-driven tumor and immune therapy resistance. Nat Commun 11, 3946, doi:10.1038/s41467-020-17739-8 (2020).

60 Tsoi, J. et al. Multi-stage Differentiation Defines Melanoma Subtypes with Differential Vulnerability to Drug-Induced Iron-Dependent Oxidative Stress. Cancer Cell 33, 890-904 e895, doi:10.1016/j.ccell.2018.03.017 (2018).

61 Acker, G. et al. The CXCR2/CXCL2 signalling pathway - An alternative therapeutic approach in high-grade glioma. Eur J Cancer 126, 106-115, doi:10.1016/j.ejca.2019.12.005 (2020).

62 Guglielmi, L. et al. Circulating miRNAs in Small Extracellular Vesicles Secreted by a Human Melanoma Xenograft in Mouse Brains. Cancers (Basel) 12, doi:10.3390/cancers12061635 (2020).

63 Yushkevich, P. A. et al. User-guided 3D active contour segmentation of anatomical structures: significantly improved efficiency and reliability. Neuroimage 31, 1116-1128, doi:10.1016/j.neuroimage.2006.01.015 (2006).

64 Livak, K. J. \& Schmittgen, T. D. Analysis of relative gene expression data using real-time quantitative PCR and the 2(-Delta Delta C(T)) Method. Methods 25, 402-408, doi:10.1006/meth.2001.1262 (2001).

65 Patel, J. K., Didolkar, M. S., Pickren, J. W. \& Moore, R. H. Metastatic pattern of malignant melanoma. A study of 216 autopsy cases. Am J Surg 135, 807-810, doi:10.1016/00029610(78)90171-x (1978).

66 Tas, F. Metastatic behavior in melanoma: timing, pattern, survival, and influencing factors. $J$ Oncol 2012, 647684, doi:10.1155/2012/647684 (2012).

67 Haueis, S. A. et al. Does the distribution pattern of brain metastases during BRAF inhibitor therapy reflect phenotype switching? Melanoma Res 27, 231-237, doi:10.1097/CMR.0000000000000338 (2017).

68 Imafuku, K. et al. Sudden Onset of Brain Metastasis despite the Use of Vemurafenib for Another Metastatic Lesion in Malignant Melanoma Patients. Case Rep Oncol 10, 290-295, doi:10.1159/000461576 (2017).

69 Indini, A. et al. A case of sudden brain metastases progression after temporary targeted therapy discontinuation: when to regret a drug holiday. Melanoma Res 31, 190-193, doi:10.1097/CMR.0000000000000725 (2021).

70 Wagle, N. et al. MAP kinase pathway alterations in BRAF-mutant melanoma patients with acquired resistance to combined RAF/MEK inhibition. Cancer Discov 4, 61-68, doi:10.1158/2159-8290.CD-13-0631 (2014).

71 Lake, B. B. et al. Integrative single-cell analysis of transcriptional and epigenetic states in the human adult brain. Nat Biotechnol 36, 70-80, doi:10.1038/nbt.4038 (2018).

72 Rajapakse, V. N., Herrada, S. \& Lavi, O. Phenotype stability under dynamic brain-tumor environment stimuli maps glioblastoma progression in patients. Sci Adv 6, eaaz4125, doi:10.1126/sciadv.aaz4125 (2020).

73 Zhang, Y. H. et al. Distinguishing Glioblastoma Subtypes by Methylation Signatures. Front Genet 11, 604336, doi:10.3389/fgene.2020.604336 (2020).

74 Capper, D. et al. DNA methylation-based classification of central nervous system tumours. Nature 555, 469-474, doi:10.1038/nature26000 (2018). 
medRxiv preprint doi: https://doi.org/10.1101/2022.02.06.22270509; this version posted February 8, 2022. The copyright holder for this preprint (which was not certified by peer review) is the author/funder, who has granted medRxiv a license to display the preprint in perpetuity.

All rights reserved. No reuse allowed without permission.

154375 Meacham, C. E. \& Morrison, S. J. Tumour heterogeneity and cancer cell plasticity. Nature 501, 328-337, doi:10.1038/nature12624 (2013). Holzel, M. \& Tuting, T. Inflammation-Induced Plasticity in Melanoma Therapy and Metastasis. Trends Immunol 37, 364-374, doi:10.1016/j.it.2016.03.009 (2016). Lehraiki, A. et al. Increased CD271 expression by the NF-kB pathway promotes melanoma cell survival and drives acquired resistance to BRAF inhibitor vemurafenib. Cell Discov 1, 15030, doi:10.1038/celldisc.2015.30 (2015).

78 Pages, C. et al. KBA.62: a useful marker for primary and metastatic melanomas. Hum Pathol 39, 1136-1142, doi:10.1016/j.humpath.2007.12.006 (2008).

1552

79 Fischer, G. M. et al. Molecular Profiling Reveals Unique Immune and Metabolic Features of Melanoma Brain Metastases. Cancer Discov 9, 628-645, doi:10.1158/2159-8290.CD-18-1489 (2019).

80 Sevenich, L. Turning "Cold" Into "Hot" Tumors-Opportunities and Challenges for RadioImmunotherapy Against Primary and Metastatic Brain Cancers. Front Oncol 9, 163, doi:10.3389/fonc.2019.00163 (2019).

81 Berghoff, A. S. et al. Density of tumor-infiltrating lymphocytes correlates with extent of brain edema and overall survival time in patients with brain metastases. Oncoimmunology 5, e1057388, doi:10.1080/2162402X.2015.1057388 (2016).

82 Colombo, E. \& Farina, C. Astrocytes: Key Regulators of Neuroinflammation. Trends Immunol 37, 608-620, doi:10.1016/j.it.2016.06.006 (2016).

83 Denkins, Y. et al. Brain metastases in melanoma: roles of neurotrophins. Neuro Oncol 6, 154165, doi:10.1215/s115285170300067x (2004).

84 Restivo, G. et al. Publisher Correction: The low affinity neurotrophin receptor CD271 regulates phenotype switching in melanoma. Nat Commun 9, 314, doi:10.1038/s41467-01802850-8 (2018).

85 Abu-Thuraia, A. et al. AXL confers cell migration and invasion by hijacking a PEAK1-regulated focal adhesion protein network. Nat Commun 11, 3586, doi:10.1038/s41467-020-17415-x (2020).

86 Kemper, K., de Goeje, P. L., Peeper, D. S. \& van Amerongen, R. Phenotype switching: tumor cell plasticity as a resistance mechanism and target for therapy. Cancer Res 74, 5937-5941, doi:10.1158/0008-5472.CAN-14-1174 (2014).

87 Rambow, F., Marine, J. C. \& Goding, C. R. Melanoma plasticity and phenotypic diversity: therapeutic barriers and opportunities. Genes Dev 33, 1295-1318, doi:10.1101/gad.329771.119 (2019).

$88 \mathrm{Du}, \mathrm{Y}$. et al. Intracellular Notch1 Signaling in Cancer-Associated Fibroblasts Dictates the Plasticity and Stemness of Melanoma Stem/Initiating Cells. Stem Cells 37, 865-875, doi:10.1002/stem.3013 (2019).

89 Schatton, T. \& Frank, M. H. The in vitro spheroid melanoma cell culture assay: cues on tumor initiation? J Invest Dermatol 130, 1769-1771, doi:10.1038/jid.2010.135 (2010). Muller, J. et al. Low MITF/AXL ratio predicts early resistance to multiple targeted drugs in melanoma. Nat Commun 5, 5712, doi:10.1038/ncomms6712 (2014). metastases implicates the PI3K pathway as a therapeutic target. Clin Cancer Res 20, 55375546, doi:10.1158/1078-0432.CCR-13-3003 (2014). 
medRxiv preprint doi: https://doi.org/10.1101/2022.02.06.22270509; this version posted February 8, 2022. The copyright holder for this preprint (which was not certified by peer review) is the author/funder, who has granted medRxiv a license to display the preprint in perpetuity.

All rights reserved. No reuse allowed without permission.

$117 \mathrm{Du}, \mathrm{W}$. B. et al. TCF19 aggravates the malignant progression of colorectal cancer by negatively regulating WWC1. Eur Rev Med Pharmacol Sci 24, 655-663, doi:10.26355/eurrev_202001_20042 (2020).

118 Lourenco, A. R. \& Coffer, P. J. SOX4: Joining the Master Regulators of Epithelial-toMesenchymal Transition? Trends Cancer 3, 571-582, doi:10.1016/j.trecan.2017.06.002 (2017).

119 Schroeder, T. et al. Mapping distribution of brain metastases: does the primary tumor matter? J Neurooncol 147, 229-235, doi:10.1007/s11060-020-03419-6 (2020).

120 Eichler, A. F. et al. The biology of brain metastases-translation to new therapies. Nat Rev Clin Oncol 8, 344-356, doi:10.1038/nrclinonc.2011.58 (2011).

121 Diener, J. \& Sommer, L. Reemergence of neural crest stem cell-like states in melanoma during disease progression and treatment. Stem Cells Transl Med 10, 522-533, doi:10.1002/sctm.20-0351 (2021).

122 Horvath, S. DNA methylation age of human tissues and cell types. Genome Biol 14, R115, doi:10.1186/gb-2013-14-10-r115 (2013).

123 Proietti, I. et al. Mechanisms of Acquired BRAF Inhibitor Resistance in Melanoma: A Systematic Review. Cancers (Basel) 12, doi:10.3390/cancers12102801 (2020).

124 Rizos, H. et al. BRAF inhibitor resistance mechanisms in metastatic melanoma: spectrum and clinical impact. Clin Cancer Res 20, 1965-1977, doi:10.1158/1078-0432.CCR-13-3122 (2014).

125 Zhao, S. et al. Selective Inhibitor of the c-Met Receptor Tyrosine Kinase in Advanced Hepatocellular Carcinoma: No Beneficial Effect With the Use of Tivantinib? Front Immunol 12, 731527, doi:10.3389/fimmu.2021.731527 (2021).

126 Oida, T. \& Weiner, H. L. Depletion of TGF-beta from fetal bovine serum. J Immunol Methods 362, 195-198, doi:10.1016/j.jim.2010.09.008 (2010).

127 Eddleston, M. \& Mucke, L. Molecular profile of reactive astrocytes-implications for their role in neurologic disease. Neuroscience 54, 15-36, doi:10.1016/0306-4522(93)90380-x (1993).

128 Sofroniew, M. V. Astrocyte Reactivity: Subtypes, States, and Functions in CNS Innate Immunity. Trends Immunol 41, 758-770, doi:10.1016/j.it.2020.07.004 (2020).

129 Cocolakis, E. et al. Smad signaling antagonizes STAT5-mediated gene transcription and mammary epithelial cell differentiation. I Biol Chem 283, 1293-1307, doi:10.1074/jbc.M707492200 (2008).

130 Bright, J. J., Kerr, L. D. \& Sriram, S. TGF-beta inhibits IL-2-induced tyrosine phosphorylation and activation of Jak-1 and Stat 5 in T lymphocytes. J Immunol 159, 175-183 (1997).

131 Padmanaban, V. et al. E-cadherin is required for metastasis in multiple models of breast cancer. Nature 573, 439-444, doi:10.1038/s41586-019-1526-3 (2019).

132 Karnoub, A. E., Der, C. J. \& Campbell, S. L. The insert region of Rac1 is essential for membrane ruffling but not cellular transformation. Mol Cell Biol 21, 2847-2857, doi:10.1128/MCB.21.8.2847-2857.2001 (2001).

\section{Acknowledgments}

This research was supported using resources of the VetCore Facility (VetImaging |

VetBioBank) of the University of Veterinary Medicine Vienna, Austria. We gratefully

thank Mascha Osang for the careful proofreading of the manuscript. We are indebted

to Petra Matylewski for excellent technical assistance. 
medRxiv preprint doi: https://doi.org/10.1101/2022.02.06.22270509; this version posted February 8, 2022. The copyright holder for this preprint

(which was not certified by peer review) is the author/funder, who has granted medRxiv a license to display the preprint in perpetuity.

All rights reserved. No reuse allowed without permission.

\section{Author contributions}

1691 JR, ES, RK, AV, TR performed experiments and wrote the manuscript; JO performed craniotomy and provided MBM; GA, BB, CS performed intracranial injections and MRT; ST

1693 performed methylation profiling; MM performed DNA sequencing; SH, PK performed 1694 immunohistological expertise and performed immunophenotyping; DW, FW provided BMC53 1695 cells, sections and expertise; FH, SKR, FG provided infrastructure; KJ, TR performed data 1696 analysis. All authors have read and agreed to the published version of the manuscript.

1697

\section{Competing interests}

1699 The authors declare no conflicting interests.

1700

\section{Funding}

$1702 \mathrm{JR}$ is a participant in the BIH-Charité Clinical Scientist Program funded by the Charité 1703 Universitätsmedizin Berlin and the Berlin Institute of Health. We thank the German Cancer 1704 Consortium (DKTK), Partner site Berlin for technical support. AV and TR received funding by 1705 the Deutsche Forschungsgemeinschaft DFG (Grant number: 392534127). 
A

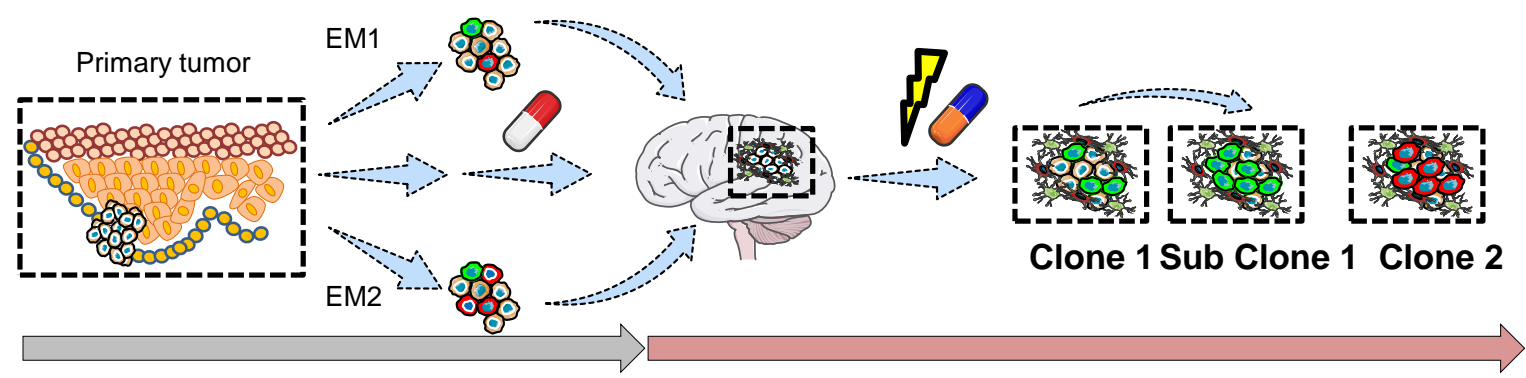

Extracranial metastasis

Intracranial metastasis

B

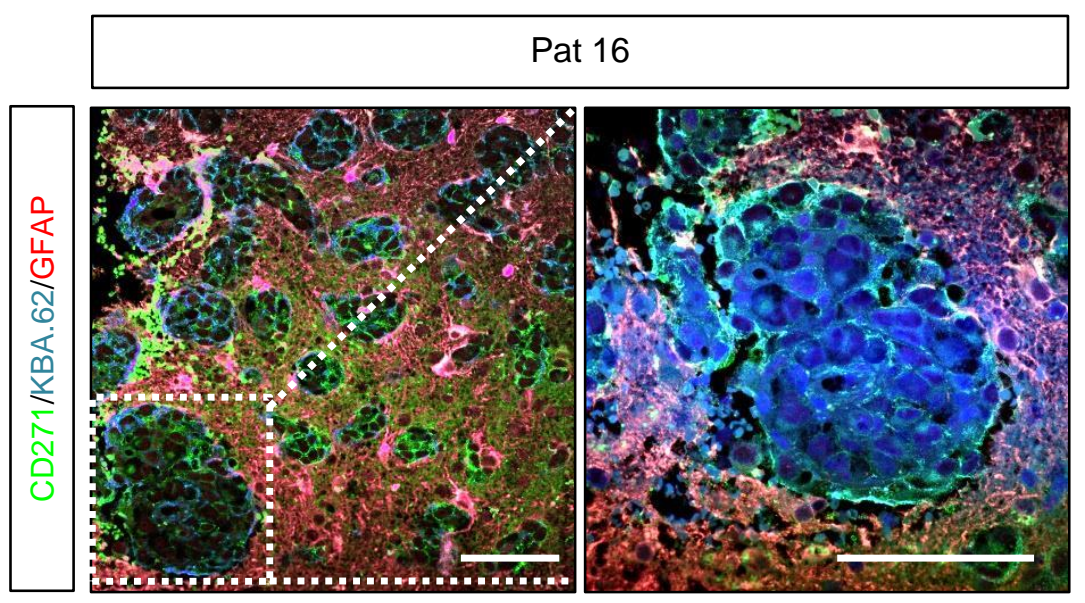

GSE77940

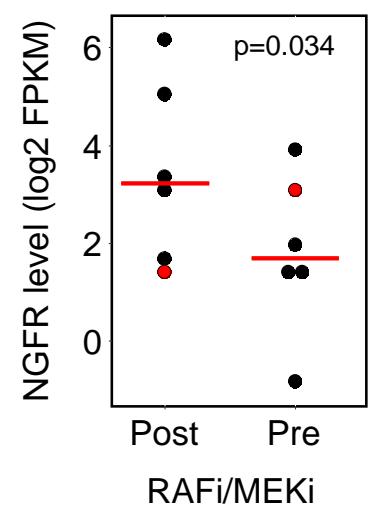

C
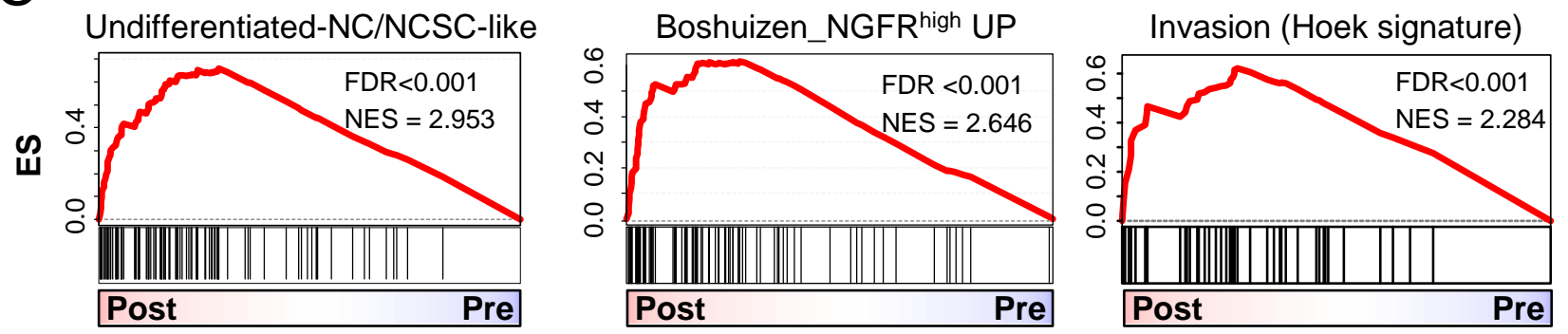

D
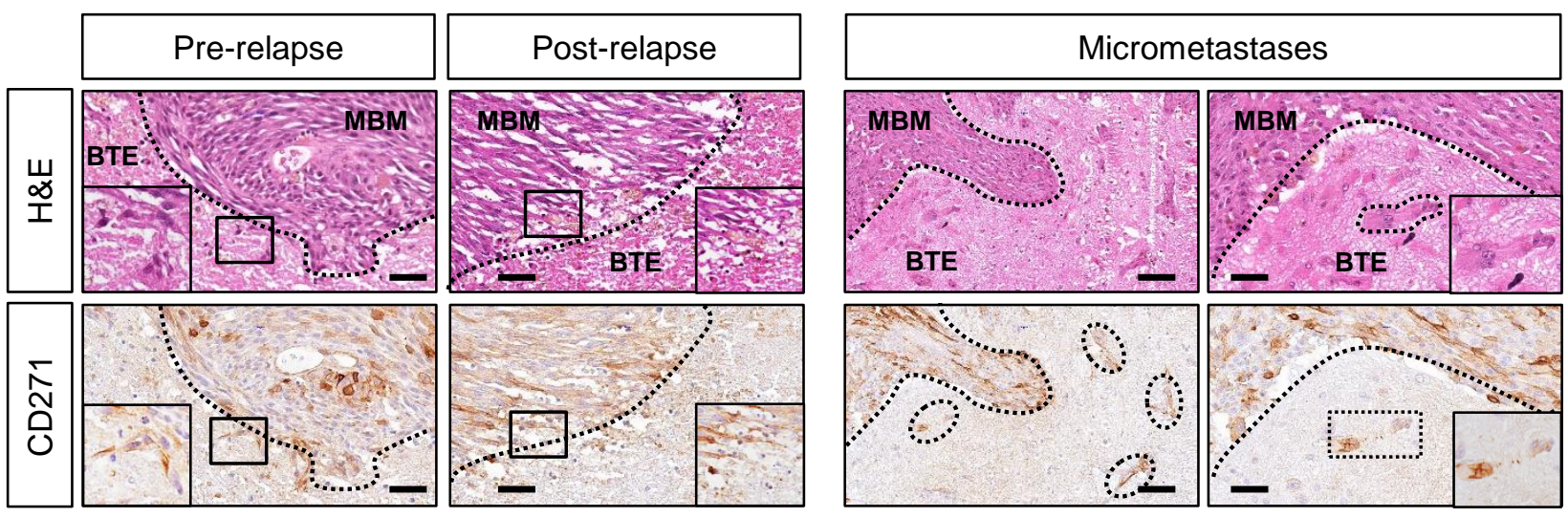


\section{A}

Occipital

Parietal Temporal

Frontal

Intradural/Leptomeningeal

Central/Insular

Extracerebral

Cerebellar Intrasellar

Pat 1 Pat 2 Pat 3 Pat 4 Pat 5 Pat 6 Pat 7

Pat 8

Pat 9 Pat 10 Pat 11 Pat 12 Pat 22

Pat 23 Pat 24

Pat 38
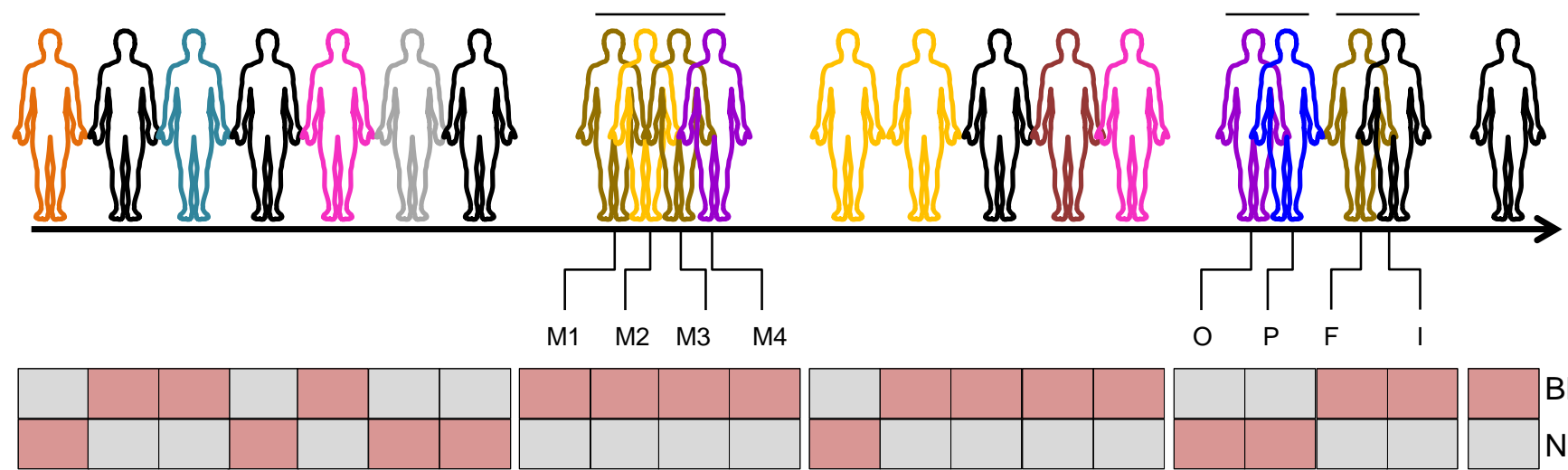

M1 M2 M3 $\quad$ M4
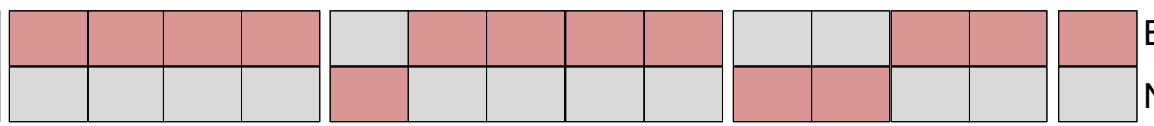

BRAF NRAS

B

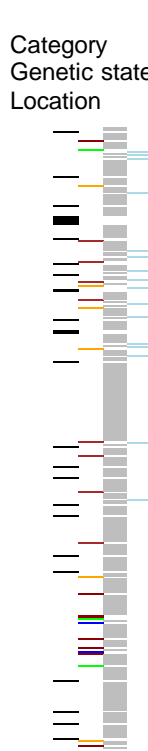

Classifier

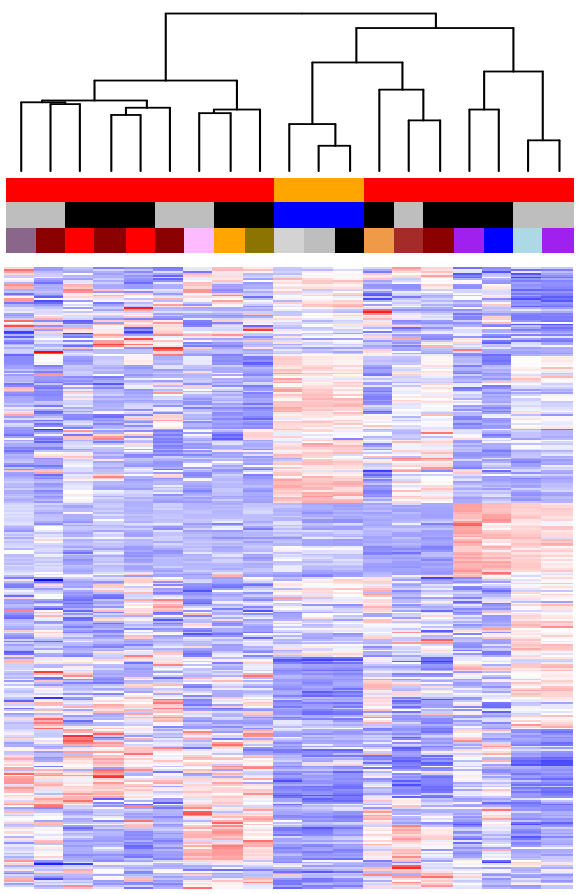

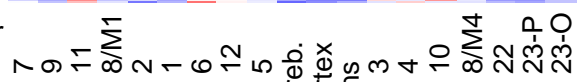

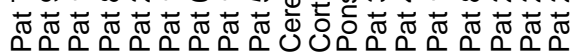

C

$\square$ BRAFmut $^{\text {m }} \square$ BRAFwt $\beta$-value $\begin{array}{lll}1.0 & 0.5 & 0.0\end{array}$

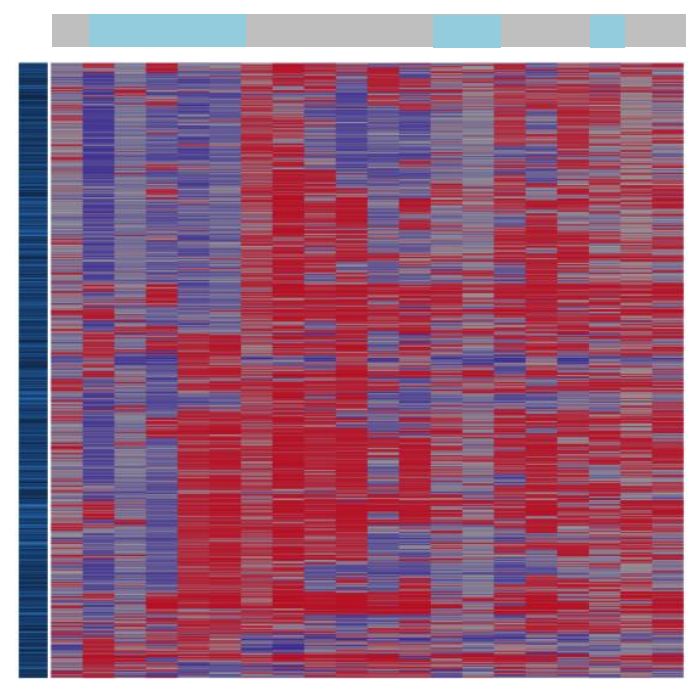

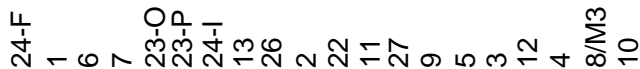

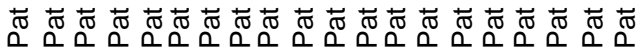

\begin{tabular}{lll}
\hline & Location: MBM & $\underline{\text { Location: BC }}$ \\
\hline$\square$ Central & $\square$ Insular $\square$ Intraspinal & $\square$ Pons \\
$\square$ Cerebellar $\square$ Intradural $\square$ Leptomeningeal & $\square$ Cortex \\
$\square$ Frontal & $\square$ Intradural $\square$ Occipital & $\square$ Cereb. \\
$\square$ Parietal & $\square$ Temporal
\end{tabular}

\begin{tabular}{|cc|}
\hline Classifier & Genetic state \\
\hline Cell adhersion $\square$ Pigmented $\square$ Invasive & $\square$ BRAFmutant \\
$\square$ Undiff NC-like $\square$ NGFRhigh $\square$ NS (not specified) & $\square$ NRAS mutant \\
$\square$ Proliferative $\quad \square$ MITF-targets $\square$ Synapse & $\square$ None/wildtype
\end{tabular}


A

B

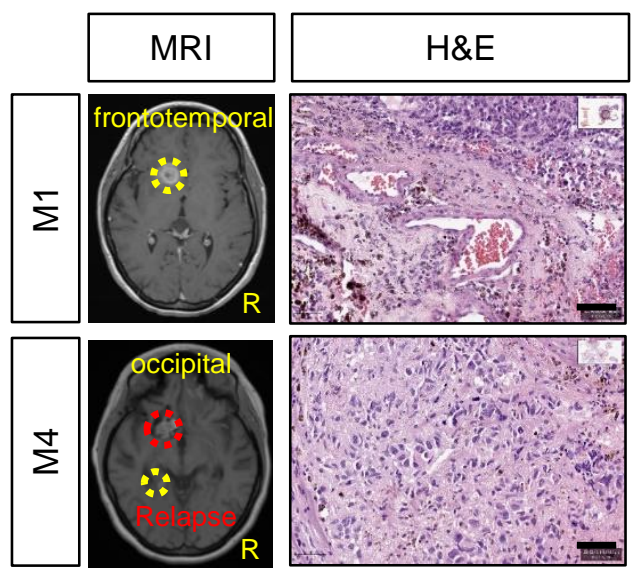

D
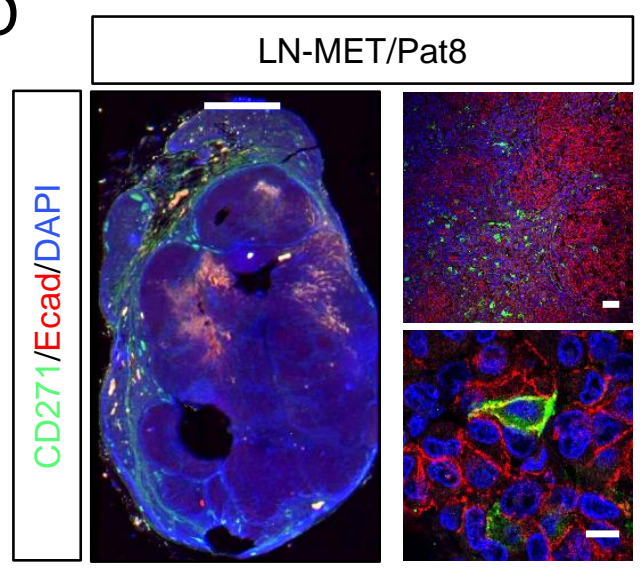

E

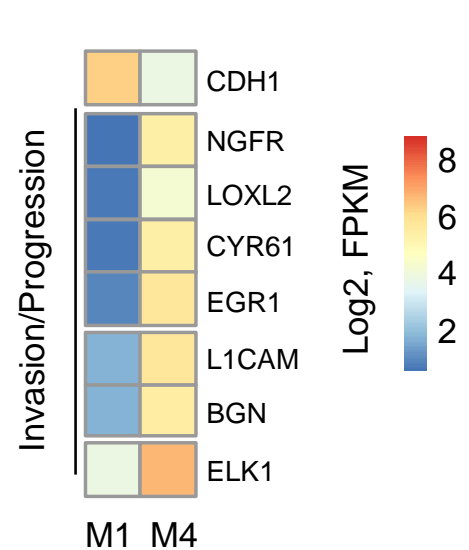

F
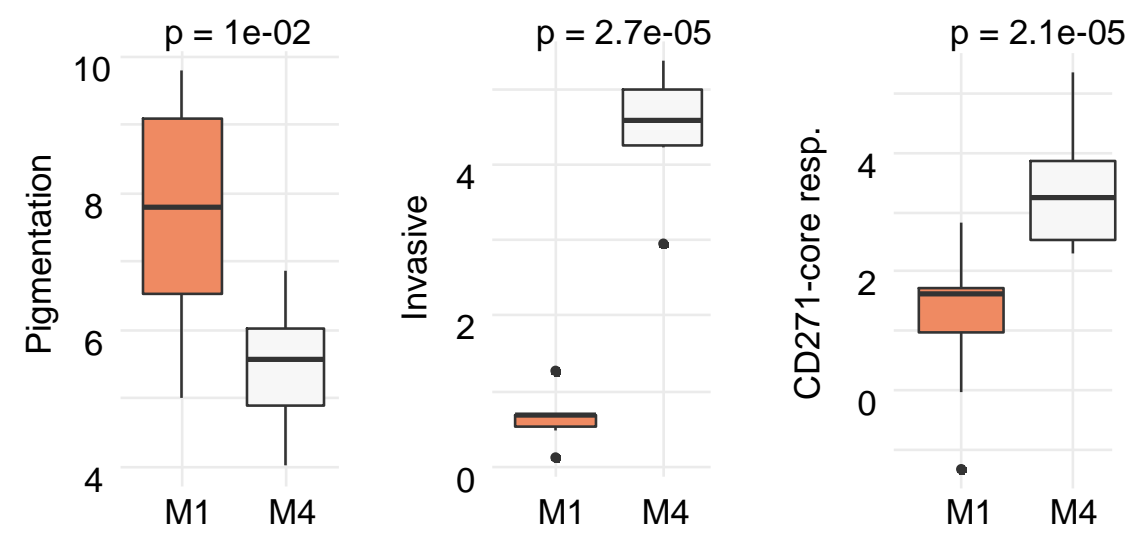

\section{C}

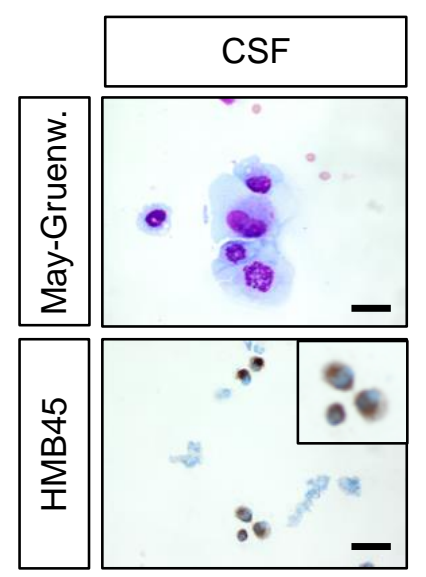

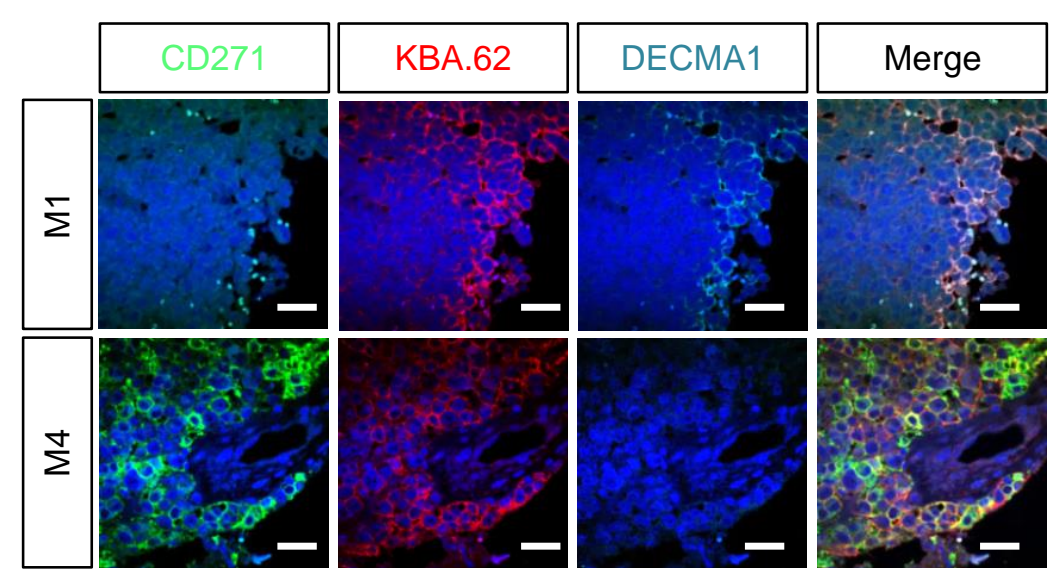


A All rights reserved. No reuse allowed without permission.
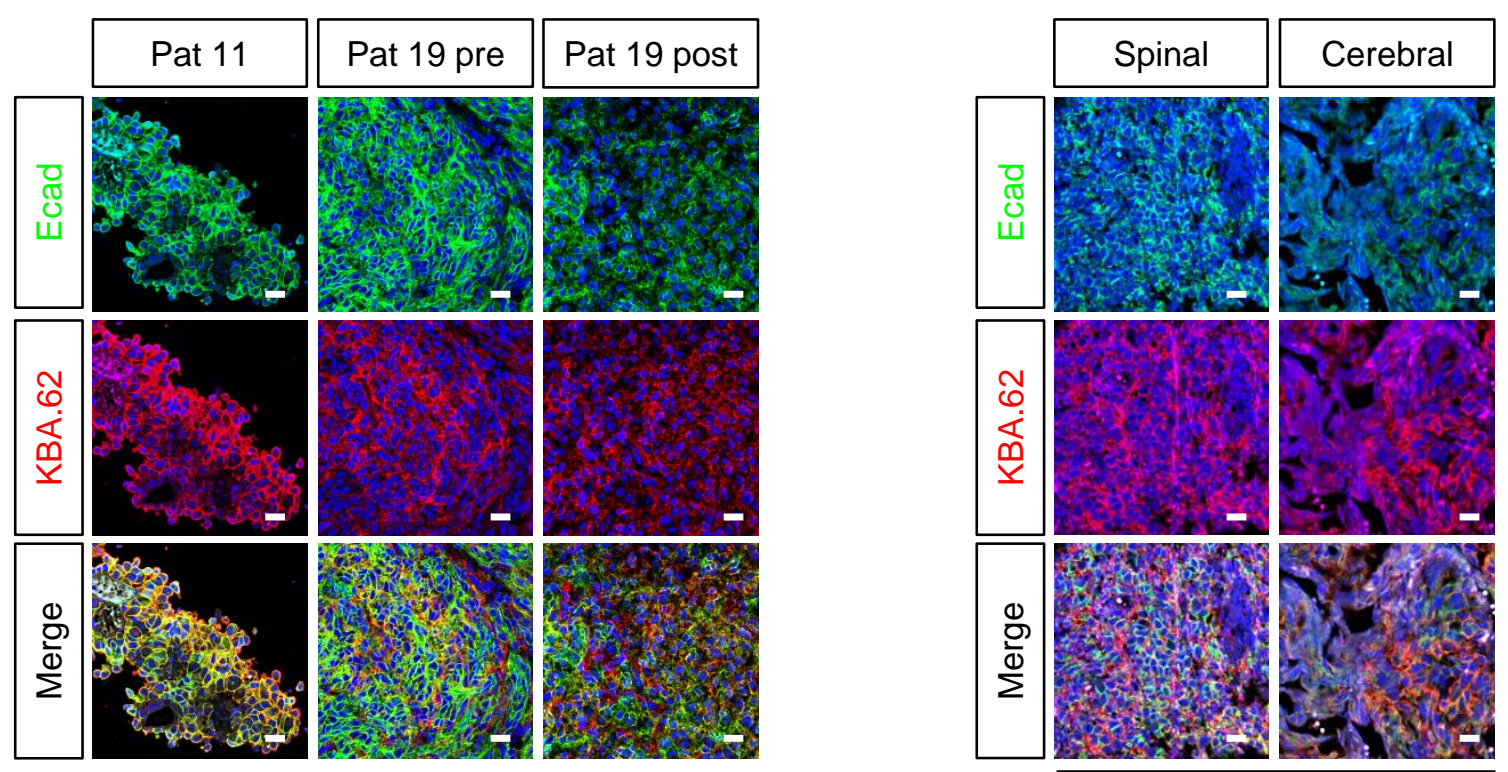

Pat 6

B

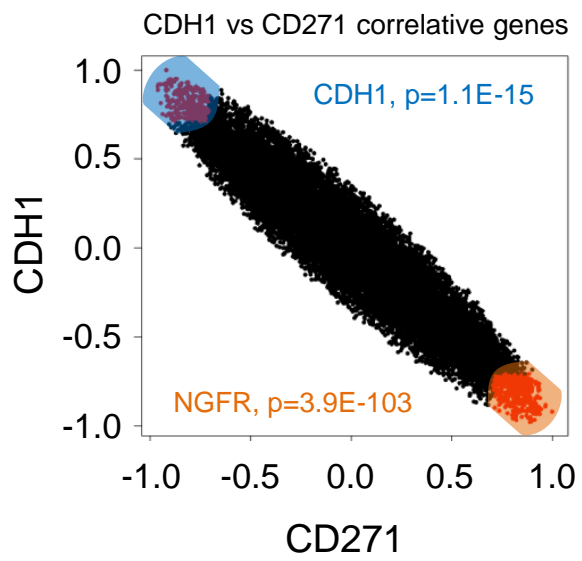

Molecular subgroups

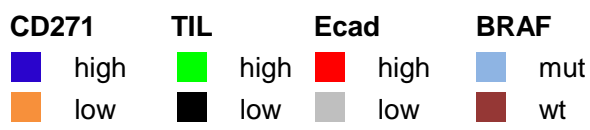

Classifier

CD271-associated Ecad-associated

- Immune modulators

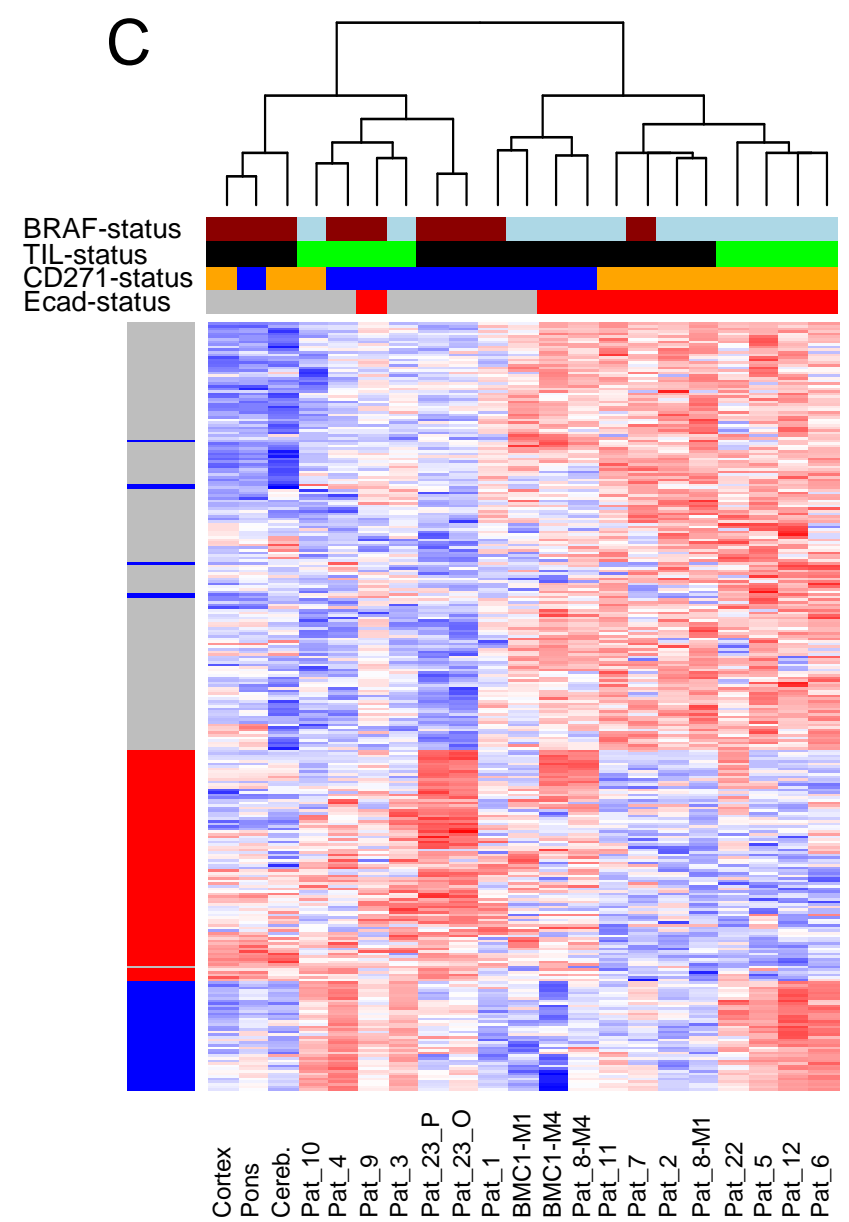

D
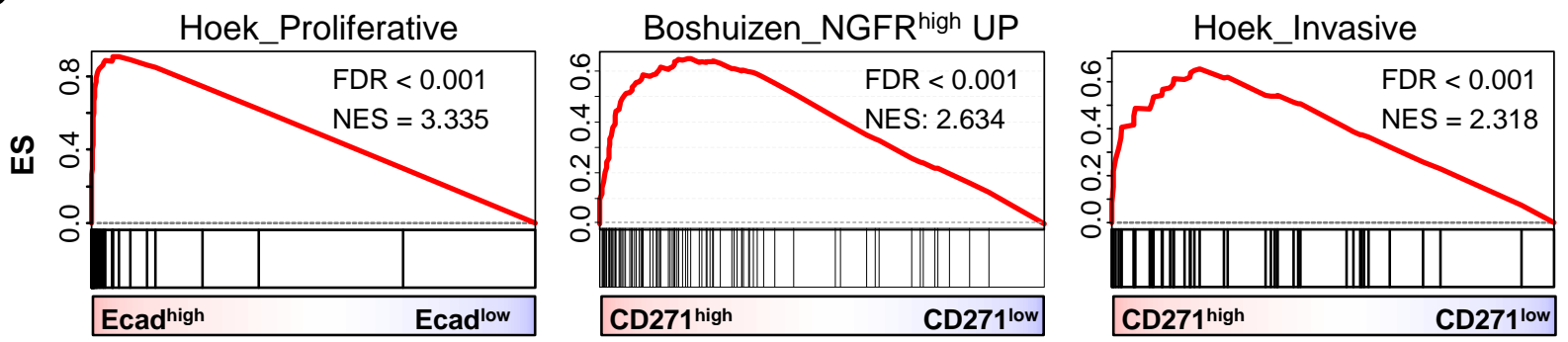
A
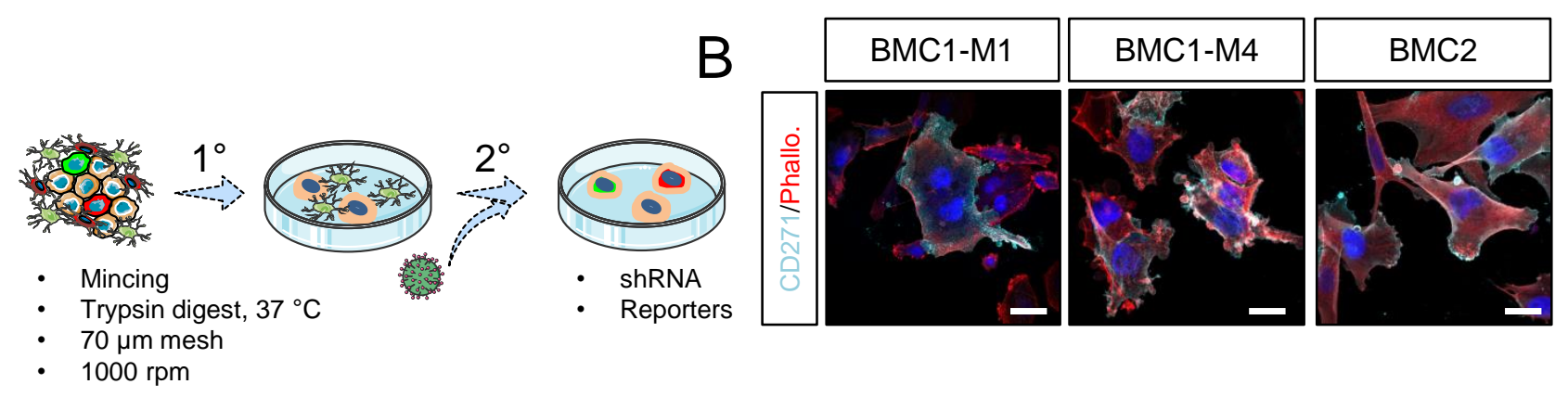

C
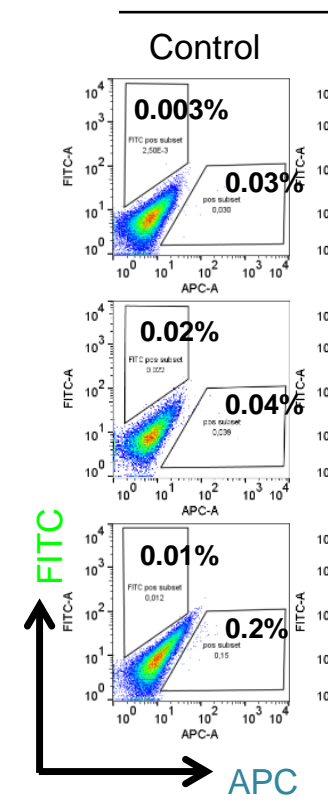

Adherent
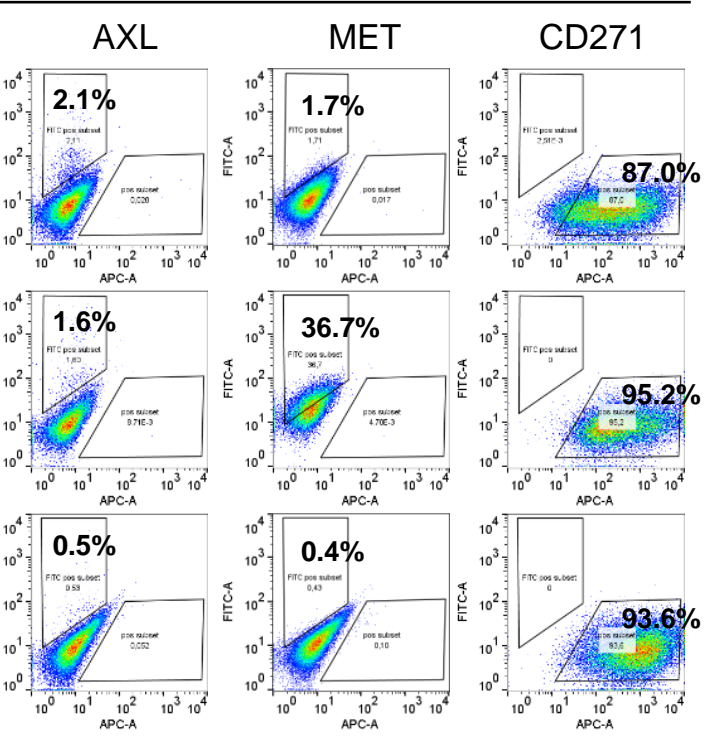

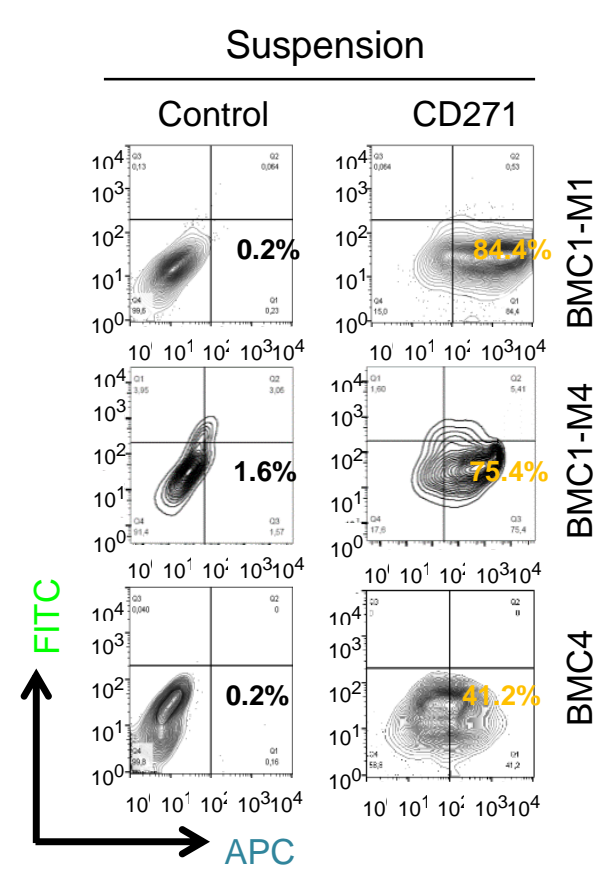

D

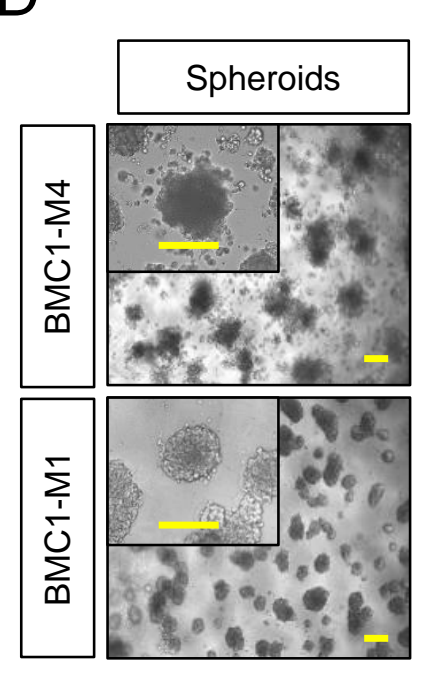

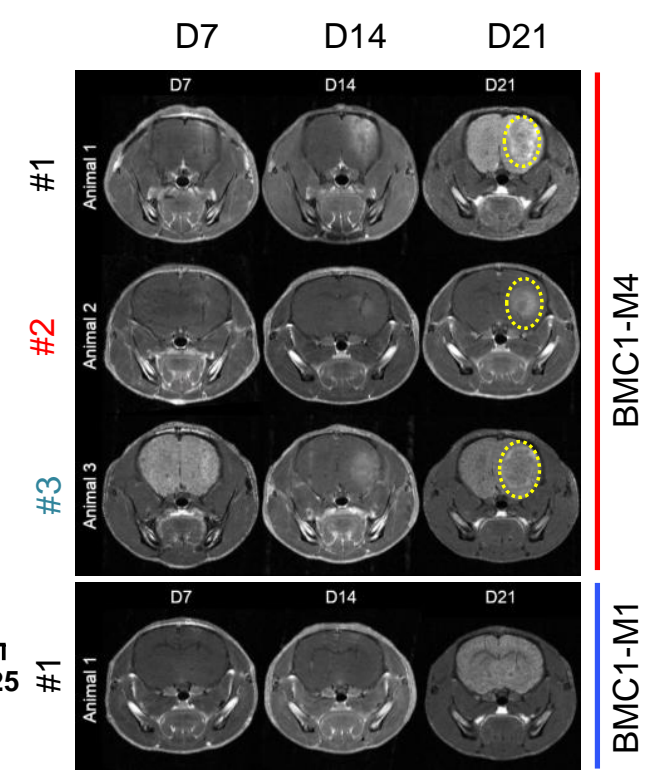


A BMC1-M1 vs M1

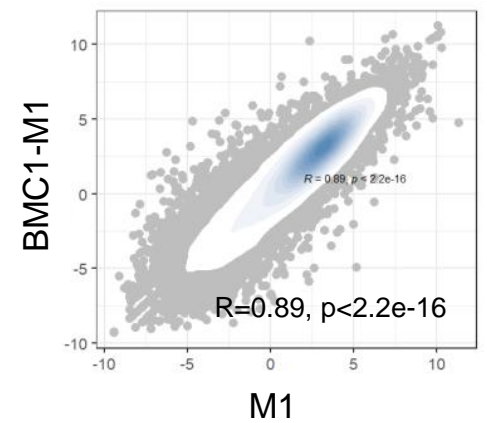

B

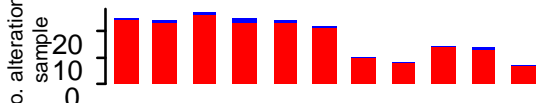
sं 0

$\begin{array}{llllllllllll}0.9 & 0.8 & 0.0 & 0.0 & 0.0 & 0.0 & 2.7 & 1.7 & 1.6 & 0.0 & \text { Unst. MSI } \\ 29.8 & 28.9 & 30.5 & 18.8 & 12.9 & 3.9 & 3.9 & 7.0 & 53.9 & 5.6 & \text { TMB-score }\end{array}$

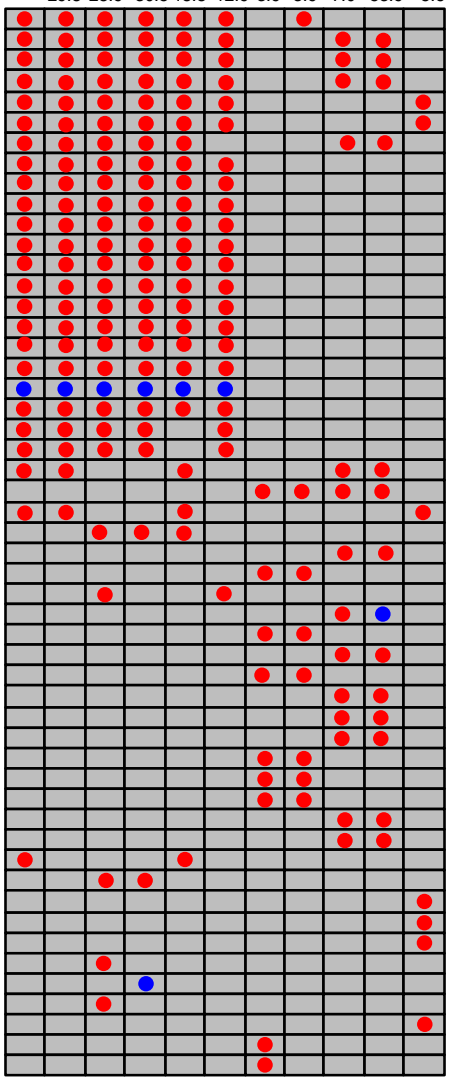

惢泣部

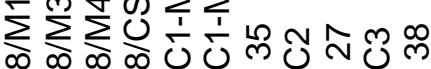

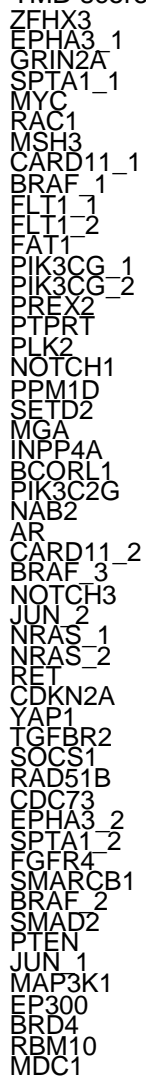

Alterations

- SNV

STOP

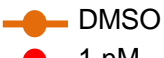

$-1 \mathrm{nM}$

$-3 \mathrm{nM}$

$-10 \mathrm{nM}$

$-30 \mathrm{nM}$

$-100 \mathrm{nM}$

- $300 \mathrm{nM}$

$-1000 \mathrm{nM}$

$-3000 \mathrm{nM}$

$10000 \mathrm{nM}$

Untreated

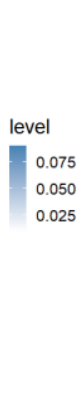

C
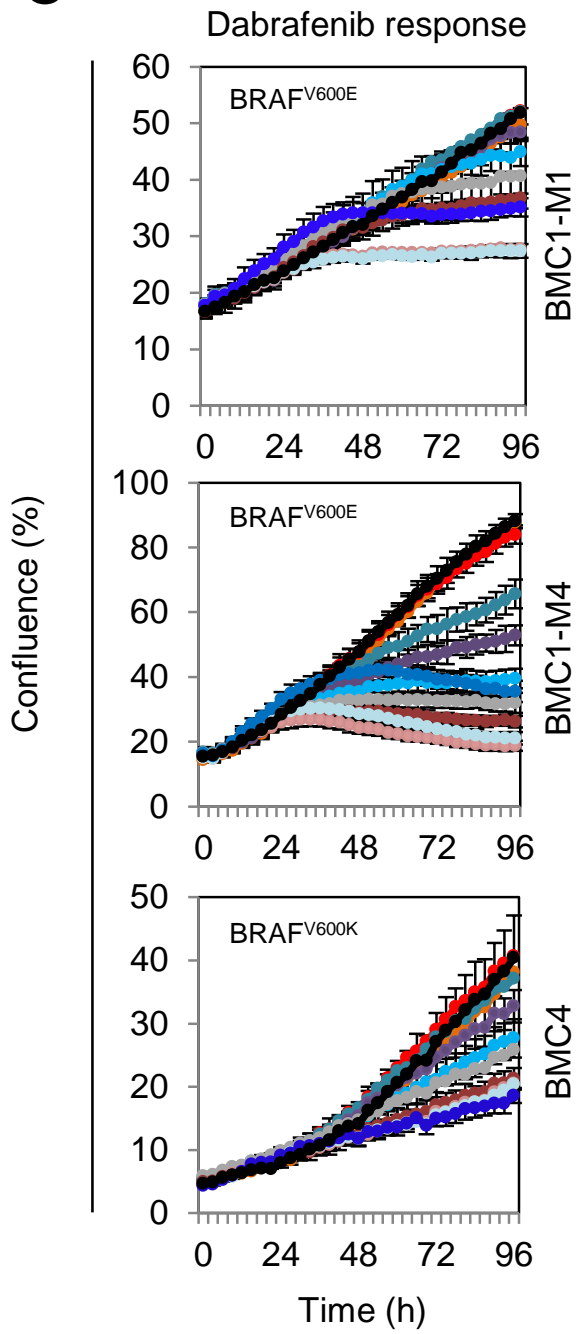

E

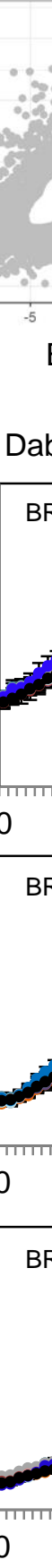

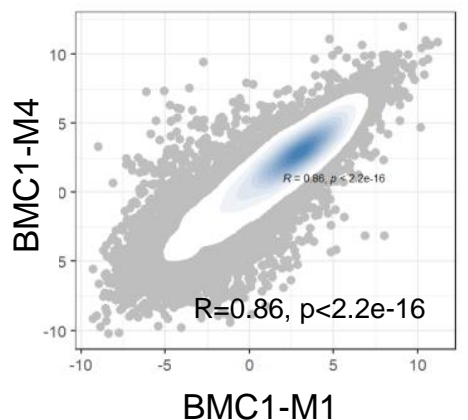

evel
0.06
0.05
0.04
0.03
0.02
0.01

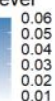

D

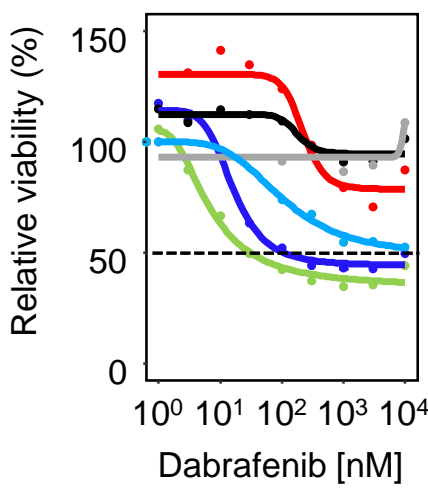

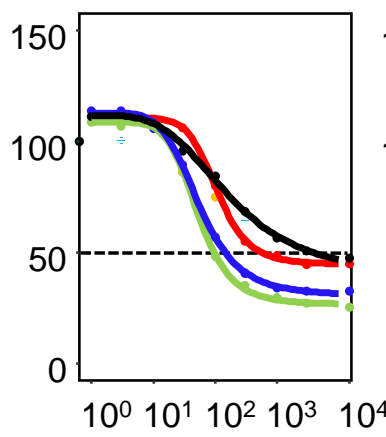

Paclitaxel [pM]

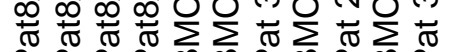

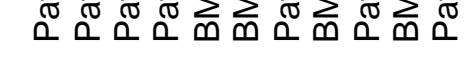


A

C

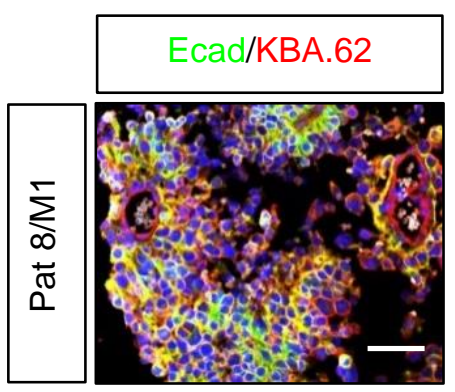

D

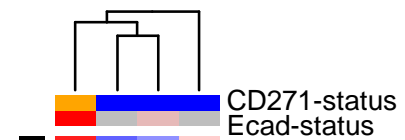

CD271

high

low

\section{Ecad}

high

low

$\stackrel{\bar{\Phi}}{=} \sum \sum_{i}^{ \pm} \sum^{ \pm} \sum_{i} \square$ Invasive

要
B

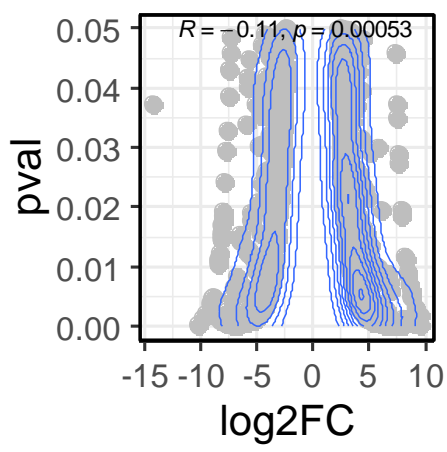

lof $1^{\circ}$ BMCs $\quad 2^{\circ}$ BMCs

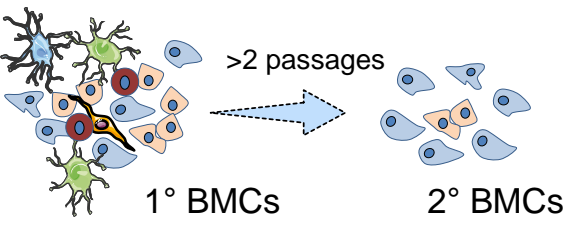

Astrocytes/Microglia
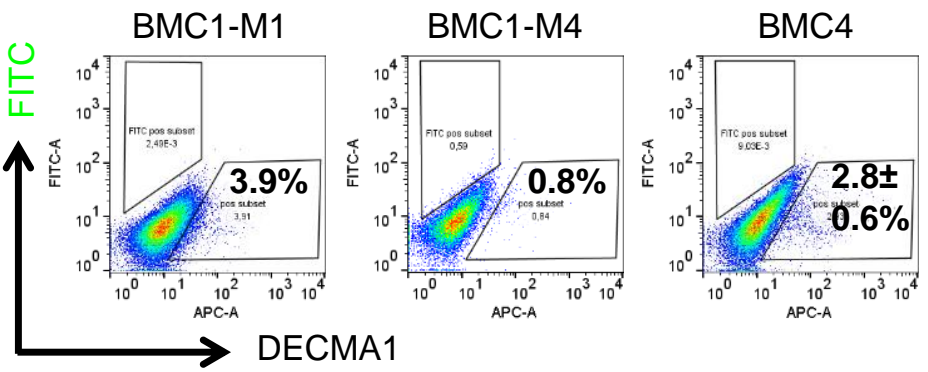

$\log 2 \mathrm{FC} \geq 2.3 ; \mathrm{p} \leq 0.05$

DEGs BMC1-M1 vs M1 DEGs M4 vs M1

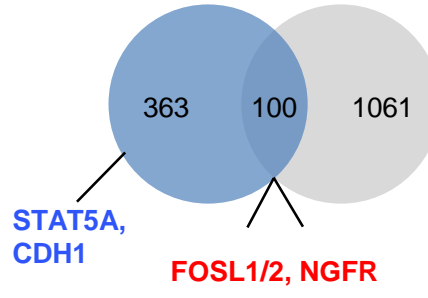

E
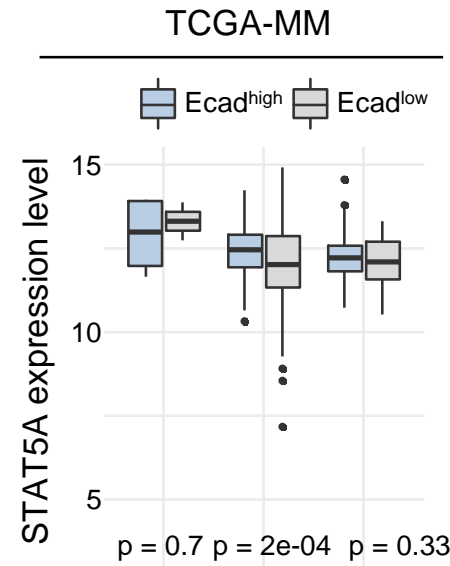

BM EM PT

$\mathrm{F}$
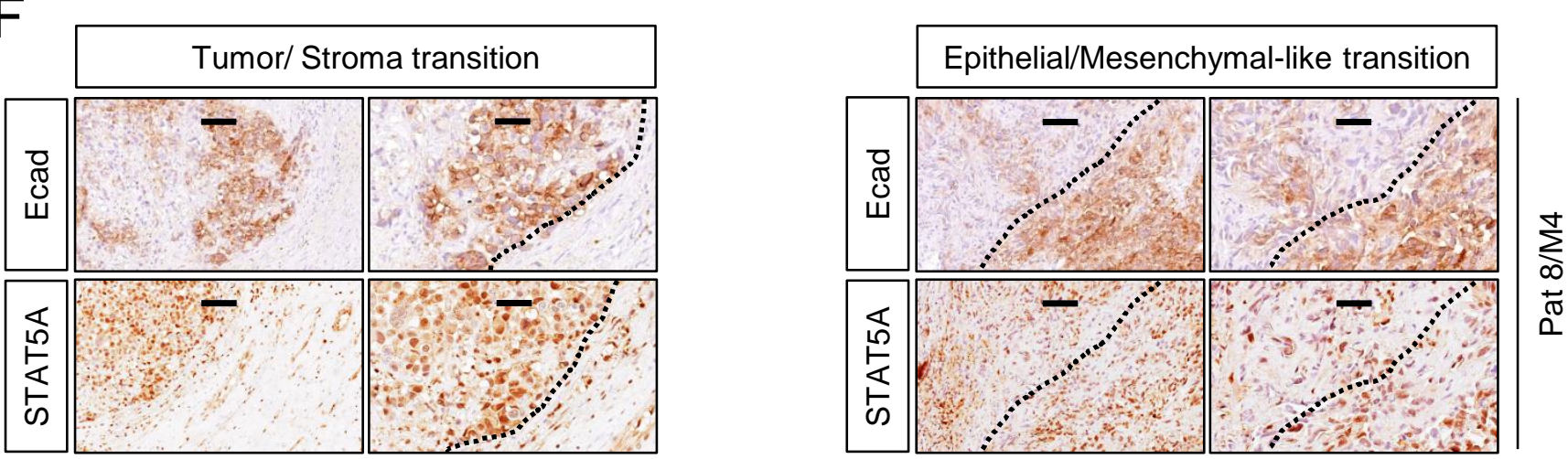
A
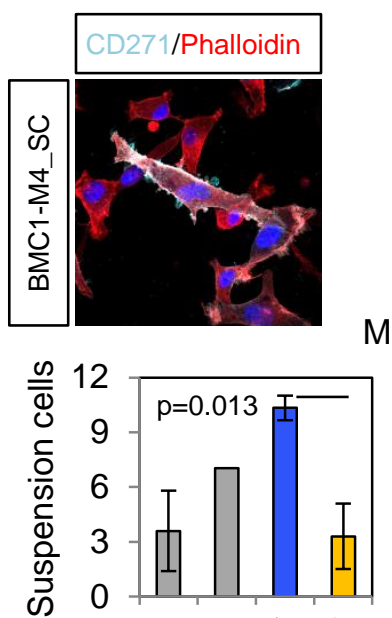

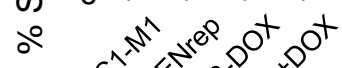

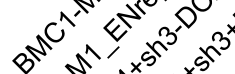

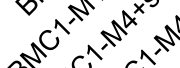

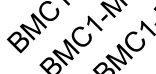

E

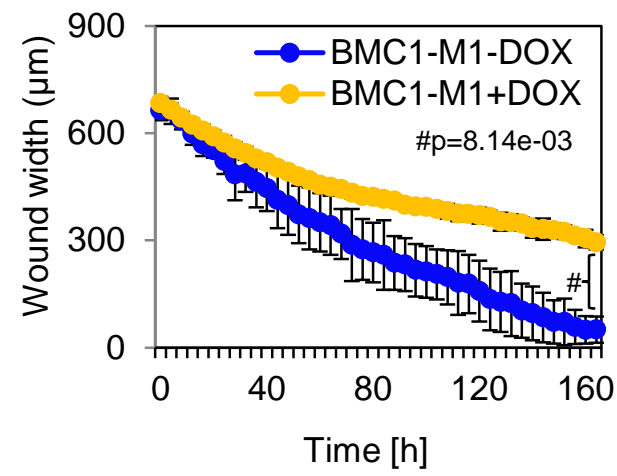

F

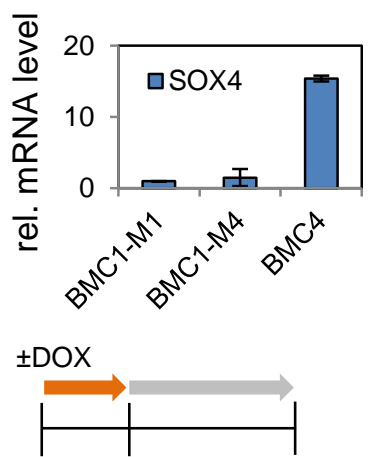

$-5 d \quad 0 \quad 4 d(96 h)$

Pre-tretment Live-cell tracking
B

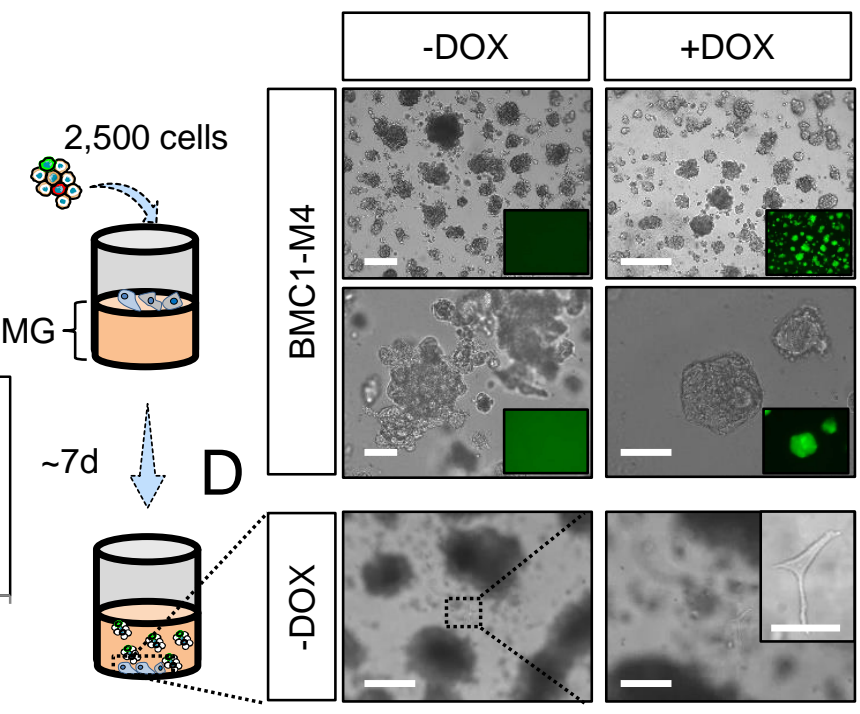

C
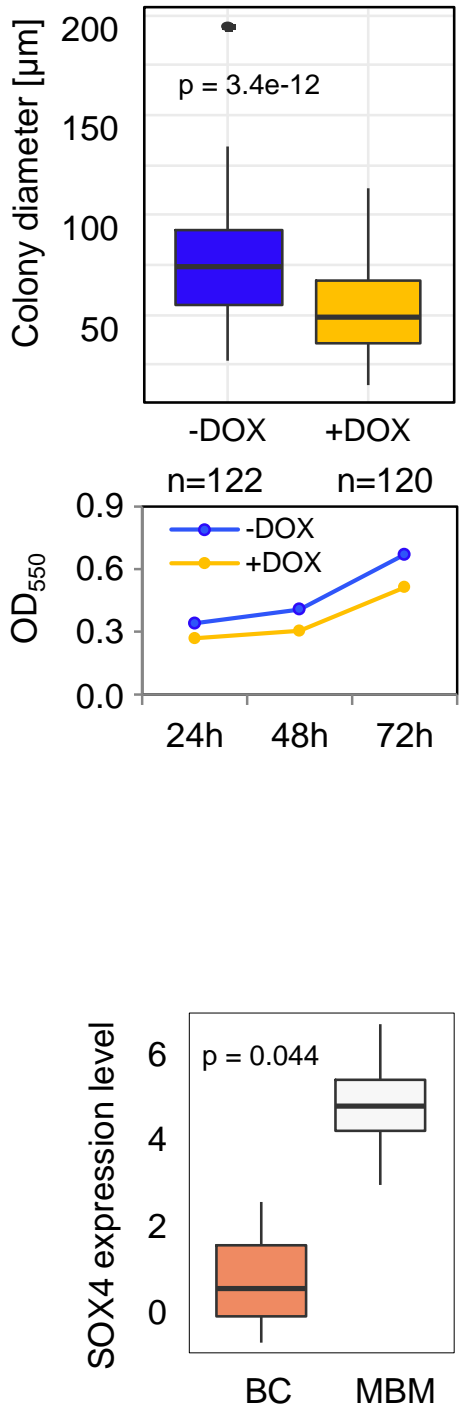

G
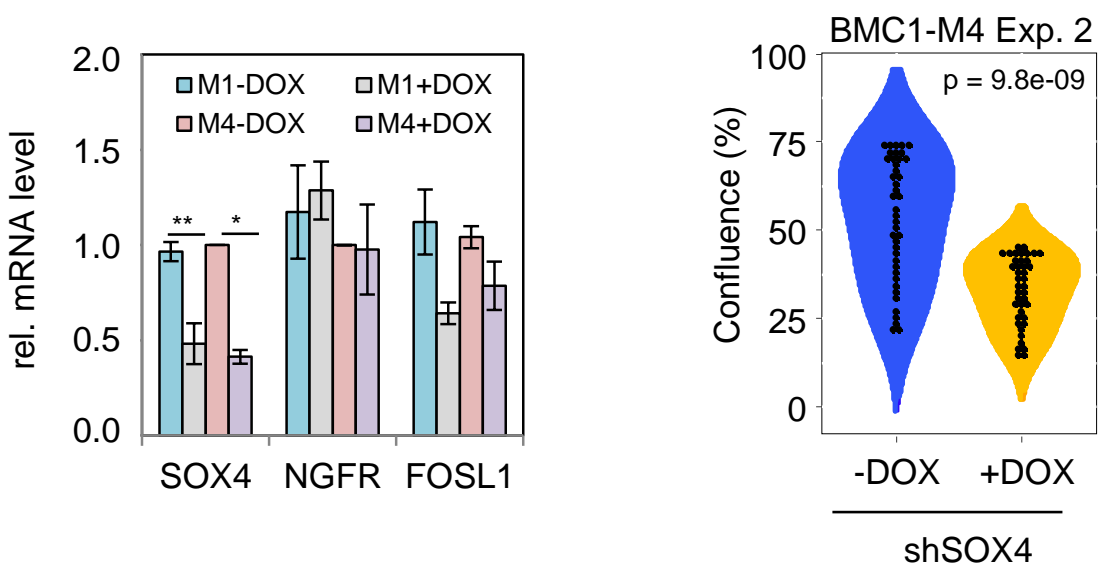